\title{
Petrographic Variability of the Fabrics of Wine Jars from Sha'ar-Ha Amakim as a Reflection of Differences in Their Provenance and Chronology
}

\author{
JACEK MichniEWICZ, Jolanta MŁYNARCZYK
}

\begin{abstract}
The aim of the present study is to investigate the relationship between the shape of the Levantine wine jars discovered at Sha'ar-Ha Amakim and the petrography of their respective fabrics. The majority of sampled ceramic material originates in well-defined chronological phases of the settlement at the site, spanning the Persian through to the Middle Roman periods. The obtained results clearly demonstrate a connection between the historical period and the raw materials used in jar production. Specifically, the jars of the Phoenician type used in the Persian and Hellenistic periods were made from a fairly homogeneous raw material, the features of which such as the content of the fragments of the coralline alga Amphiroa confirm the previous results of the investigations of jars whose fabric has been considered as Phoenician. On the other hand the bag-shaped jars, especially those of the Hellenistic period, are characterized by the more diversified petrography of their fabrics, suggesting that they were produced by a number of local workshops to supply the needs of local wineries. Finally, the Roman period brings an abrupt change in the production of wine containers, with the introduction of the common use of the fine ferruginous soil rich in quartz silt.
\end{abstract}

Keywords: Sha'ar-Ha Amakim, wine jars, Persian period, Hellenistic period, Roman period, jars petrography

Jacek Michniewicz, Institute of Geology, Adam Mickiewicz University, Poznań; jacekm@amu.edu.pl

Jolanta Młynarczyk, Institute of Archaeology, University of Warsaw, Warszawa; susyam@wp.pl

As is known from written sources and archaeological finds, Galilee was a region abounding not only in olive groves, but also in vineyards. ${ }^{1}$ The wine that came from them was probably an object of regional trade, especially intense in the borderland between western Galilee and southern Phoenicia. Differences in the shape of wine containers found in this region reflect not only chronological divisions, but are also indicative of the origin of their

\footnotetext{
${ }^{1}$ Safrai 1994: 132-133.
} 
individual models, that is, of 'coastal' Phoenician and 'inland' non-Phoenician tradition respectively. Those types and their derivatives kept developing over centuries, giving rise to several typo-chronological variants (see below).

It is obvious that the centres producing each type of wine $\mathrm{jar}^{2}$ were associated with specific areas of grapevine cultivation. However, any closer identification of places producing amphorae is impossible without an in-depth analysis of the mineral composition of the raw material used, often termed 'fingerprints' of individual workshops. Such a study requires both optical microscope observations and an analysis of the chemical composition of the ceramic mass of the containers.

In the framework of the research project entitled 'Provenance of the Palestinian-type amphorae from the Graeco-Roman period at the Sha'ar-Ha Amakim and Tell Keisan sites (Galilee, Israel) in the light of petro-archeological studies', samples of jars found at three different localities in western Lower Galilee (Sha'ar-Ha Amakim) and southern Phoenicia (Tell Keisan and Tel Akko) were selected for the above-mentioned analyses. However, the subject of the present paper are the samples only from Sha'ar-Ha Amakim, firstly because they constitute the most numerous group, and then because of the specific geographical situation of the site. Its location on a stretch of Via Maris, between the plain of Akko (the Zevulun valley) which was a part of southern Phoenicia, and the plain of Esdrelon (Yezreel valley) made it an ideal place for interregional trade exchange.

The excavations at Sha'ar-Ha Amakim (1984-1998) were carried out by Arthur Segal from Haifa University and Yehuda Naor, one of the founders of the kibbutz on the grounds of which the ancient site had been discovered, with Jolanta Młynarczyk in charge of the stratigraphy and ceramics from 1994. Within the excavated area, seven strata have been distinguished, the lowermost of which (stratum VII) has been dated to the fourth century $\mathrm{BC}$, and the uppermost one (stratum I) to the Roman period. In correlation with these strata, the ceramic material has been divided into Phases A through F. While the eldest Phase A was connected with some scanty architectural remains of the Persian and Early Hellenistic periods, ${ }^{3}$ Phase B was represented, among others, by a rich assemblage of the third to earlier second century BC pottery sealed in an abandoned wine cellar of a mansion. ${ }^{4}$ The final phase of the settlement, Phase F, was best represented by the domestic pottery assemblage from Cistern D, dated to the third and into the fourth century AD.

The ceramics and other objects found at Sha'ar-Ha Amakim are eloquent in illustrating the changes in the ethnicity of its inhabitants. In the Persian to the Late Hellenistic periods it was a gentile site, which after $200 \mathrm{BC}$ passed from Ptolemaic into Seleucid hands. However, at the very turn of the second century $\mathrm{BC}$ this area was conquered by either Aristoboulos I or Alexander Jannaeus and became a part of the Jewish Hasmonean kingdom. This may have been also the place of Gaba Hippeon, where Herod the Great settled the veterans of

\footnotetext{
${ }^{2}$ See: Finkielsztejn 2006: 254 n. 3, for the explanation of the term 'jar', commonly used to describe the Levantine amphorae.

${ }^{3}$ For the stratigraphy of the site and the phasing of the ceramics, see: Młynarczyk 2009a.

${ }^{4}$ So-called Cistern G/R, see: Młynarczyk 2000.
} 
his cavalry. In the Herodian period, on the eve of the First Revolt, at least some part of the population must have been Jewish, to judge by the finds of fragmentary Jewish ritual vessels of chalk stone (kallalim). ${ }^{5}$ After a possible episode of a Roman outpost established there during the Revolt, Sha'ar-Ha Amakim became a modest settlement, once again Jewish, in the second-third centuries AD, probably connected with the nearby Beth Shearim.

All those historical periods and stratigraphical phases attested at Sha'ar-Ha Amakim abounded in storage jars, destined mostly for the wine, but some perhaps also for olive oil. Moreover, one should note the presence of a number of rims pertaining to the jars of a period earlier than any architectural remains discovered at the site, that is to the last phase of the Iron Age II (late seventh and sixth centuries $\mathrm{BC}$ ). ${ }^{6}$

The research questions we posed at the start of our project were the following:

- How many 'ceramic workshops', understood as distinct 'petrographic groups', could take part in providing Sha'ar-Ha Amakim with wine amphorae (or possibly interchangeably with the olive ones)? How far do the kinds of material distinguished on the basis of macroscopic observation coincide with divisions obtained as a result of physico-chemical examinations?

- Does the material used to produce amphorae of the Persian and Hellenistic periods (fifth to second century $\mathrm{BC}$ ) differ from that used to produce vessels performing the same function in the Roman period (first century BC to third century AD)? Can we speak of a technological evolution over the ages?

- Is it possible to indicate the source (sources?) of the material used to produce the amphorae found in Sha'ar-Ha Amakim?

- Does the physico-chemical examination of amphorae identical in shape and similarly dated, but differing in colour confirm their different workshop origin?

A total of 152 samples were examined: 134 fragments of jars (Levantine amphorae, among them a few may have pertained to other large closed forms such as pithoi or jugs), plus 10 samples of jugs and eight samples of other ceramic objects.

In order to facilitate the comparisons between the jar samples representing vessels of different (Phoenician versus non-Phoenician) origin, as well as their predecessors and later developments, each typo-group in our study received a numeric symbol: 1 for jar shape of Phoenician origin (with chronological subdivisions), 2 for jar shape of non-Phoenician origin (with chronological subdivisions), 3 for water jugs whose fabrics are visually comparable to those of jars, and 4 for objects other than jars and jugs. The relevant groups can be characterized as follows:

\footnotetext{
5 For chalk vessels from Sha'ar-Ha Amakim as 'reliable indicator of Jewish presence', see: Burdajewicz 2009: 203-206 and Fig. 1. In Yodefat, with its definitely Jewish population, c. 110 fragments of stone vessels were found (Aviam 2015: 122-123).

${ }^{6}$ Burdajewicz 2015; that a settlement existed at Sha'ar-Ha Amakim during the Persian period has been recognized by Lehmann 2001: 98, Fig. 3.9 (site no. 110).
} 


\section{GROUP 1A (Fig. 1)}

The Phoenician type jar, hole-mouthed, known among other things as a 'shouldered', 'waisted', 'torpedo' or 'carinated-shoulder' jar, its capacity amounting to 10-13 liters. In Sha'ar-Ha Amakim it occurs in the Persian and Early Hellenistic periods, ${ }^{8}$ with a number of residual rim fragments from the late Iron Age II - Iron Age III. ${ }^{9}$ A detailed typology of the Phoenician jars according to their shape has recently been presented by Elisabeth Bettles on the basis of the finds from Sarepta. ${ }^{10}$ It is unfortunately useless for our material in which usually only rim fragments are preserved, while the body shape can rarely be reconstructed.

Macroscopically, the prevailing fabric of the jars in our group 1a is the so-called Phoenician semi-fine ware, first described by Andrea Berlin at Tel Anafa in the Hula valley, ${ }^{11}$ and said to have come from the Tyre area. Actually, the same fabric characterizes the jars from Sarepta. ${ }^{12}$ Another recognizable fabric, less represented at Sha'ar-Ha Amakim, but very common at Tell Keisan in the Persian and Hellenistic periods, is the so-called Light White ware. ${ }^{13}$

\section{GROUP 1B (Fig. 2:1-3)}

A late Phoenician type jar, hole-mouthed with a thick out-rolled rim; the body is bag--shaped and mildly wheel-ridged (except for the shoulder); it has twisted handles and a knob base. As with most jars of our group 1a it represents the so-called Phoenician semi-fine ware. ${ }^{14}$ Gerald Finkielsztejn, who describes the form in question as the 'ribbed pear-shaped amphora', believes that this type appeared in the second century BC. ${ }^{15}$ Indeed, in Tel Anafa the type was present by $125 \mathrm{BC},{ }^{16}$ and in Tel Dor it made its appearance in the contexts of the second half of the second century BC. ${ }^{17}$ At Sha'ar-Ha Amakim, however, its examples, represented by just rims, handles and body sherds, have occurred in context with Late Hellenistic and Early Roman pottery. They are also known in Yodefat. ${ }^{18}$ In the Late Hellenistic stratum at

${ }^{7}$ According to Zemer 1978: 24-25, nos 18-22, Pls 6-7 (date range of the seventh/sixth to fourth century $\mathrm{BC})$.

${ }^{8}$ For the Hellenistic-period examples of our group 1a present at other sites, see e.g. Tell Keisan: Briend, Humbert 1980: P1. 7 (niveau 2); Akko: Regev 2010: 123-124, Figs 1-2 and Smithline 2013: 94, Fig. 11:6-8; Horbat Uza: Smithline 2009: 147, Fig. 4.8:7-8.

9 Burdajewicz 2015: 14, Fig. 5.

${ }^{10}$ Bettles 2003a; 2003b; see also: Reynolds 2005: P1. 12, Figs 84-88 ('Persian - Hellenistic Tyrian and Sidonian amphorae').

11 Berlin 1997: 9-10; Młynarczyk 2001: 247.

12 Bettles 2003a; 2003b.

${ }_{13}$ For the macroscopic description of the ware, see: Młynarczyk 2001: 240-241.

14 It seems, however, that a parallel form was known in other wares as well, see: Młynarczyk 2009b:

Fig. 5:12 (from Sha'ar-Ha Amakim) and nn. 45-46 (from Ramat Hanadiv and Machaerus).

15 Finkielsztejn 2006: 255, Fig. 3.

16 Berlin 1997: 155, PW 480-483.

${ }_{17}$ Guz-Zilberstein 1995: 312, Type JR 3, Fig. 6.38:6-9.

18 Avshalom-Gorni, Getzov 2002: 79, Fig. 5.2:1-2. 


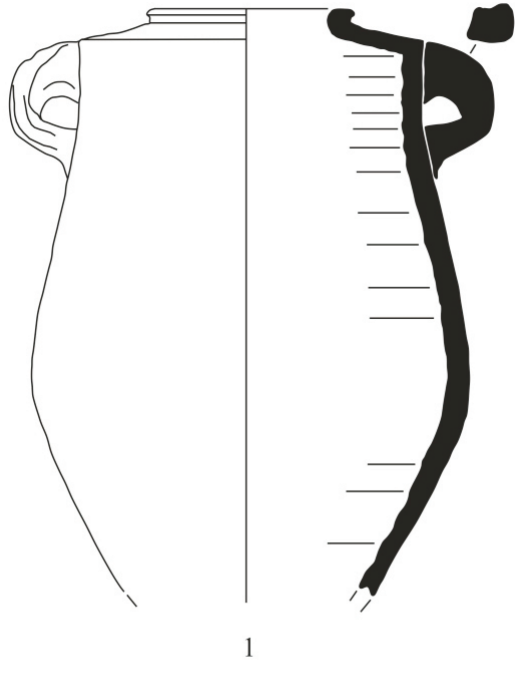

0

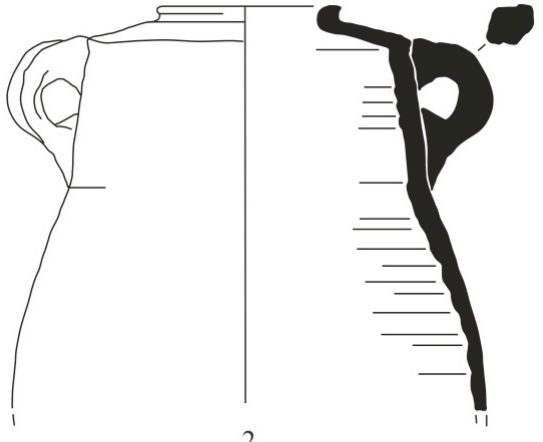

2

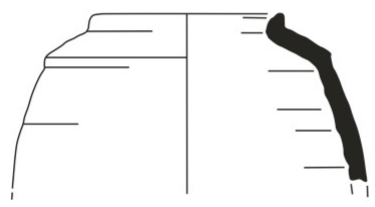

3

1. Examples of 'carinated-shoulder' Phoenician type jars from Sha'ar-Ha Amakim (group 1a): 1. inv. no. 192.2; 2. inv. no. 864.1; 3. inv. no. 192.5 (Drawing: M. Burdajewicz).

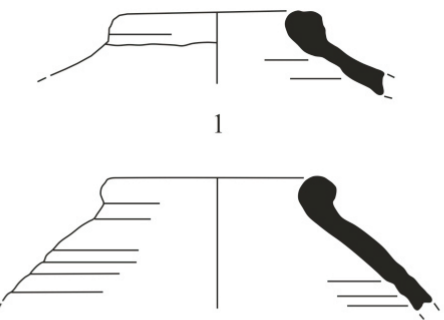

2

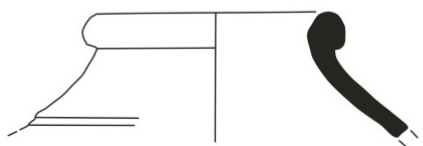

3

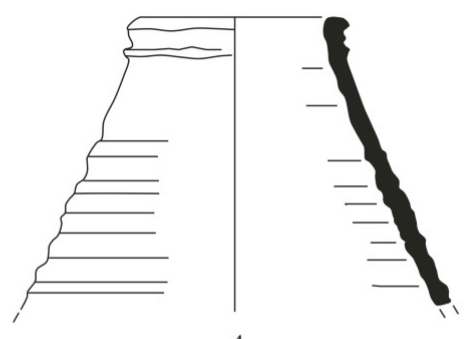

4

0
$10 \mathrm{~cm}$

2. Examples of late Phoenician type jars (1-3, group 1b) and post-Phoenician type jar (4, group 1c) from Sha'ar-Ha Amakim: 1. inv. no. 818.4; 2. inv. no. 940.1; 3. inv. no. 200.19; 4. inv. no. 169.1 (Drawing: M. Burdajewicz). 
Shiqmona (a destruction layer dated to between 130 and $125 \mathrm{BC}),{ }^{19}$ the capacity of such jars amounted to 26 liters, ${ }^{20}$ while Avshalom Zemer illustrates a similar jar with a capacity of $c .19$ liters. ${ }^{21}$ Occasionally, the handles of the jars in question bore stamp impressions. The stamps with inscriptions in Phoenician have firmly been identified as belonging to Tyrian producers, yet Sha'ar-Ha Amakim has yielded three stamp impressions in Greek which remain neither deciphered nor connected to any manufacturing center. ${ }^{22}$

\section{GROUP 1C (Fig. 2:4)}

Post-Phoenician type jars, hole-mouthed elongated, of the Early Roman to Roman period. They occur at Sha'ar-Ha Amakim in just few fragments which represent more than one fabric, all of them untypical for our site, to judge by visual examination. ${ }^{23}$ They are not stratified, but the accompanying pottery would place them in the first and second centuries $\mathrm{AD}$. One rim fragment (sample SF-109, not illustrated) pertains to a Roman-period 'cigar-shaped' jar with parallels in Yoqne'am, ${ }^{24}$ Ramat Hanadiv ${ }^{25}$ and Shiqmona, ${ }^{26}$ while another jar fragment (sample SFx-113: Fig. 2:4) resembles by its form the Tyrian holemouth amphora of the late second century AD. ${ }^{27}$

\section{GROUP 2A (Fig. 3)}

A bag-shaped jar, in the shape variant characteristic of the Persian and Hellenistic periods. ${ }^{28}$ It is virtually neckless, with everted rim and oval-sectioned, usually ridged, handles set below the shoulder.

The manufacturing of such jars at Tel Michal during the fifth century BC has been attested by kiln finds. ${ }^{29}$ At Nahal Tut (near Yoqne'am) jars of this form were found in a context dated to the last quarter of the fourth century BC. ${ }^{30}$ As a matter of fact, they were common in a wide area from Judea and Sharon in the south through Samaria to the Galilee in the north, including the whole coastal belt. ${ }^{31}$ It is to be noted that during the later Persian and

19 Elgavish 1976: 65-67.

20 Elgavish 1976: 74-75, Fig. 6:18, P1. 15:D.

21 Zemer 1978: 32, no. 27, Pl. IX, vol. c. 19 liters (misdated to the fifth-fourth centuries BC).

${ }^{22}$ Finkielsztejn 2006: 258; 2009: 140-142, does not exclude that they may have come from Tyre as well.

${ }_{23}$ Młynarczyk 2009b: Fig. 5:13-14 (our samples SF-109 and SFx-113, respectively).

24 Avissar 1996: 74, Fig. XII.7:7.

${ }_{25}$ Calderon 2000: 92-93, P1. I:28.

26 Elgavish 1977: Pl. XIX:155.

27 Reynolds 1997-1998: 81, Fig. 200. A fragment of a comparable amphora from the nearby Jalame (Johnson 1988: Fig. 7-50, no. 747, undated) is made of 'fine red clay with pale yellow slip'. See also: Reynolds 2005: P1. 12, Figs 89-91 ('Tyrian amphorae of the Roman period'); Avshalom-Gorni, Getzov 2002: 79, Fig. 5.2:4 (from Yodefat).

${ }^{28}$ Finkielsztejn 2006: 255, Fig. 4.

29 Singer-Avitz 1989: Fig. 9.4.

30 Alexandre 2006: 156 and Figs 50:1-10, 52:1-3, 8-12, 53:12-17, 60:2-18, 61:4 and 9-15.

${ }^{31}$ For references, see: Młynarczyk 2000: 226-228, nn. 7-10. An example with a Phoenician inscription was found at Bat Yam near Ashdod in southern Israel, see: Shapira 1966: 10, P1. 4A. 


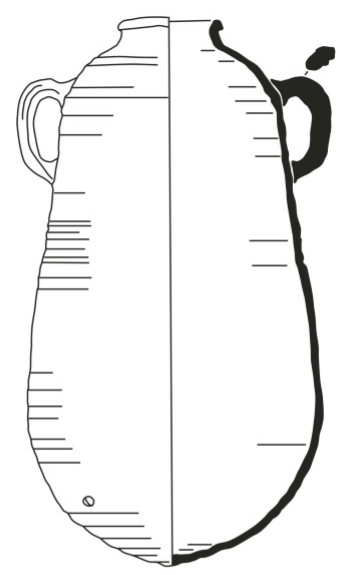

1

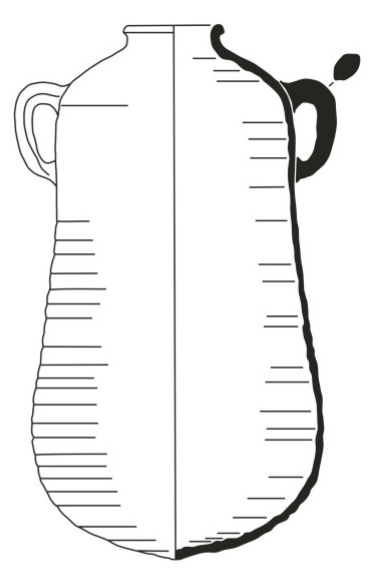

2

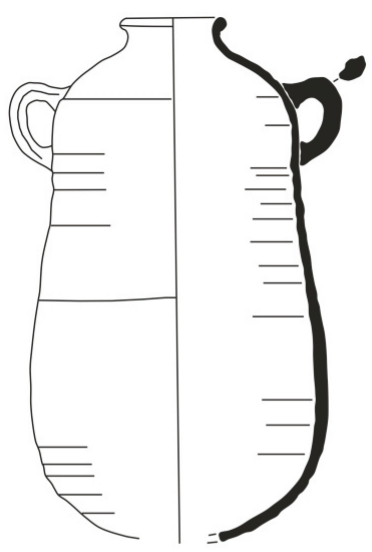

3

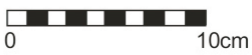

3. Examples of bag-shaped Hellenistic jars from Sha'ar-Ha Amakim (group 2a): 1. inv. no. 897.7; 2. inv. no. 890.8; 3. inv. no. 889.7 (Drawing: M. Burdajewicz).

the Hellenistic periods at a number of northern sites the jars of our group 2a co-occurred with those of groups $1 \mathrm{a}$ and $1 \mathrm{~b}$. That was the case with Yodefat, ${ }^{32}$ Tell Keisan, ${ }^{33} \mathrm{Tel} \mathrm{Michal,},{ }^{34}$ Akko, ${ }^{35}$ and Horbat Uza stratum 10 (Hellenistic). ${ }^{36}$

In Sha'ar-Ha Amakim, the jar of group 2a is best represented by several restorable examples found in a household wine cellar ('cistern' G/R), whose one-time fill was fairly closely dated to the end of the third century and the first half of the second century BC. $^{37}$ The restorable jars were designed to contain 25-26 litres of wine.

At the coastal Shiqmona (the modern Haifa, c. $15 \mathrm{~km}$ to the west of Sha'ar-Ha Amakim), similar jars continued to appear in a Late Hellenistic layer; they had capacity of c. 25 liters, but also of just 17 liters(!), and were said to be about half as common as the co-occurring jars of our group $1 \mathrm{~b} .{ }^{38}$ Also at Dor, the type was still used in the second half of the second century BC. ${ }^{39}$ At Tel Anafa in Hula valley, where there was a gap in occupation

32 Avshalom-Gorni, Getzov 2002: 77, Fig. 5.1:1-3 (our group 2a, late variant) and 80, Fig. 5.2:1 (our group 1b); Aviam 2015: 111, Fig. B.

33 Briend, Humbert 1980: Pls 7-8 (niveau 2: Persian/Hellenistic).

34 Singer-Avitz 1989: 139-142, Fig. 9.17, nos 1 (our 2a, described as 'elongated' type) and 3 (our group 1a).

35 Regev 2010: 123-124, Figs 1-2 (our groups 1a-b: 'Phoenician amphora Forms 1-2') and Fig. 3 (our group 2a: 'Local amphora Form 3'); Smithline 2013: 94 and Fig. 11:6-8 (our group 1a) and 9 (our group 2a).

36 Smithline 2009: 146-147, Fig. 4.8, nos 1-6 (our group 2a) and nos 7-8 (our group 1a).

37 Młynarczyk 2000; 2009b: Fig. 1-3.

38 Elgavish 1976: 74, Fig. 6:19 and P1. 15:E.

${ }^{39}$ Guz-Silberstein 1995: 311, type JR 1, subtypes a-b, apparently of local manufacture: Fig. 6.35:5 and 8-10; Fig. 6.36:1, 4 and 6-9. Cf. also Lapp 1961: type 11.3, rim variant F, example from Shechem, dated to $150-100$ BC. 
between $c$. 250 and $125 \mathrm{BC}$, a related shape appeared only in the last quarter of the second century BC.

The jars of group 2a at Sha'ar-Ha Amakim were made of more granular fabrics than those of groups 1a-b; sometimes they were fired with a core, and normally had a pale-coloured surface. Visually, the fabrics can be described as gritty orange, pale brown, pale pink, light greyish brown etc, often with a range of mineral inclusions (white, light and dark grey, brown). However, some of the examples can be identified as the Light White ware, the same as occurring in group $1 \mathrm{a}$.

\section{GROUP 2B (Fig. 4)}

A bag-shaped jar of the Roman period, ${ }^{40}$ present at Sha'ar-Ha Amakim from the latter first century $\mathrm{BC}$ to the third-fourth centuries $\mathrm{AD} .{ }^{41}$

In the second half of the first century BC (phase D1), the Roman-period type of Levantine jars made its mass appearance at Sha'ar-Ha Amakim. These containers were thin-walled, hard-fired, usually smaller than those of our group 2a; perhaps some of them may have held olive oil rather than wine. The occurrence of the group $2 b$ jars at our site covers the phases D, E and F. Initially they had an elongated, round-bottomed body which with time became shorter and wider ('bulbous'), typically a ridge between the shoulder and an upright neck with a variety of rim profiles.

The fabric of the jars of the latter first century $\mathrm{BC}^{42}$ and those of the first-second centuries $\mathrm{AD}^{43}$ is very dense and extremely 'metallic', with a full or partial ash-grey core and white mineral inclusions seen mostly as eruptions to the surface, which is beige, pale pink, light greyish brown or reddish brown. Some jars preserve the remains of a thin and flaky beige slip. Subsequently, in the second/third century AD and later, the jars present at Sha'ar-Ha Amakim have no grey core anymore, their break assuming the hues of red with abundant white grits, the surface fired to dark pink, orange-red, reddish brown. ${ }^{44}$

The final period of habitation of Sha'ar-Ha Amakim has been dated to between the second and the third/fourth centuries $\mathrm{AD}$ by the material found in unsealed Stratum I and in the fill of a water cistern (Cistern D). The latter, apparently in use down to the first half of the fourth century, yielded ceramics of Phase $\mathrm{F}$ and residual objects of Phases D-E. Thus, the assemblage from Cistern D include jar forms apparently of the first/second centuries $\mathrm{AD},{ }^{45}$ as well as the later ones. ${ }^{46}$

\footnotetext{
40 The form described as 'barrel-shaped' by Avshalom-Gorni, Getzov 2002.

${ }^{41}$ Byzantine-period version, type 2c, absent from Sha'ar-Ha Amakim, is represented only by a couple of samples from Tell Keisan, not discussed in the present paper.

${ }^{42}$ Díez Fernández 1983: 181-182 and 229, T 1.3, with floruit between 50 BC and AD 50; see: Młynarczyk 2009b: Fig. 7:1.

43 Díez Fernández 1983: T 1.8 and T 1.7 respectively; see: Młynarczyk 2009b: Fig. 7:2-3.

44 Díez Fernández 1983: T 1.8 and T 1.9.

45 Młynarczyk 2009b: Fig. 7:6, corresponding to Díez Fernández 1983: type T 1.2, dated to c. AD 50-150.

${ }^{46}$ Młynarczyk 2009b: Fig. 7:7, possibly to be identified as Díez Fernández 1983: type T 1.9 of the late second to early fourth century AD; close to Johnson 1988: Fig. 7-53, no. 809, in the same fabric.
} 

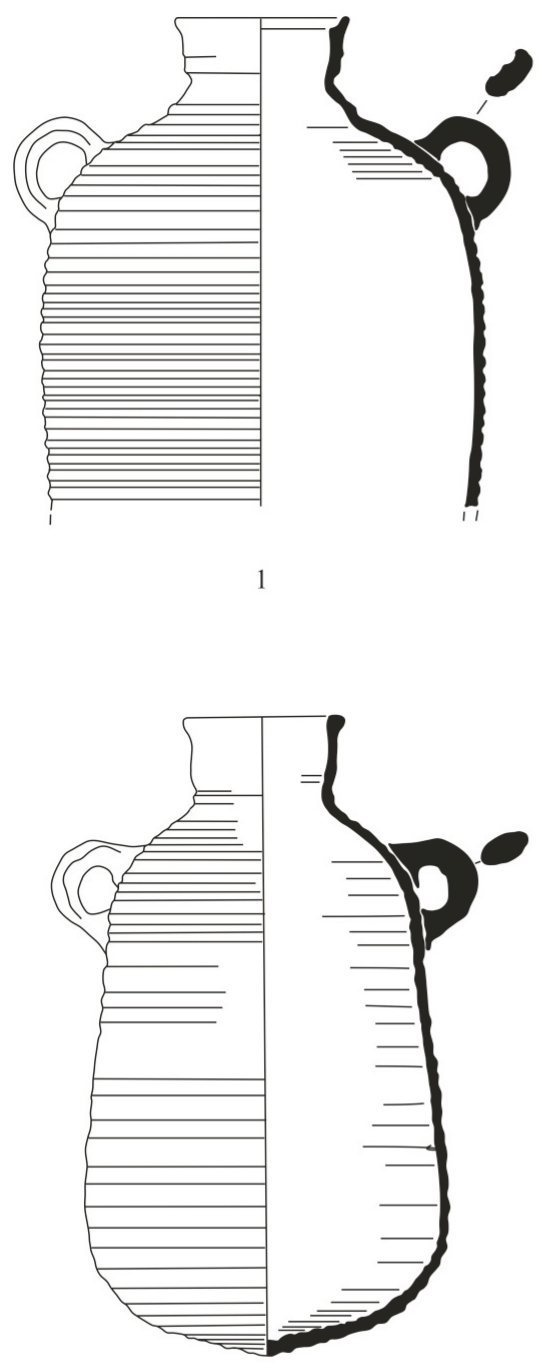

3
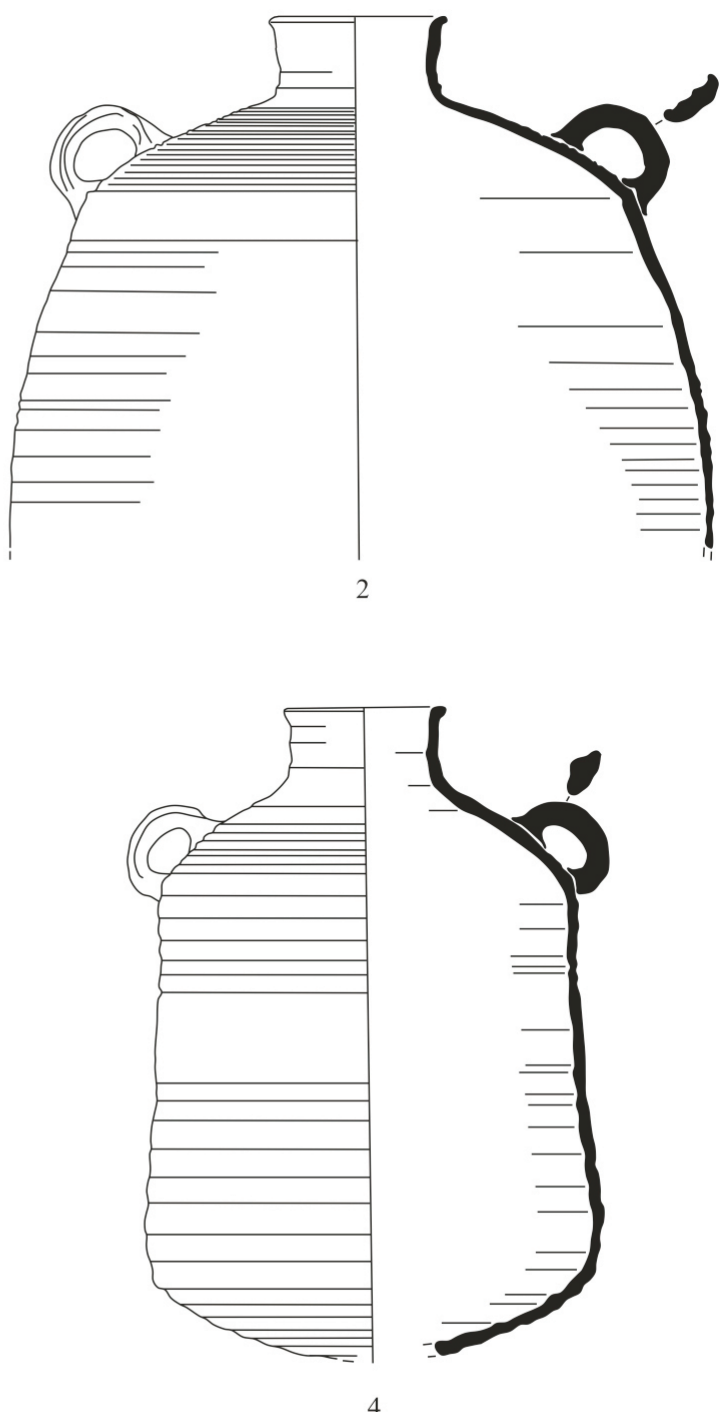

4

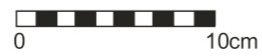

4. Examples of bag-shaped Roman jars from Sha'ar-Ha Amakim (group 2b): 1. inv. no. 806/809/836; 2. inv. no. 185.1; 3. inv. no. 744.1; 4. inv. no. 737.1 (Drawing: M. Burdajewicz). 
For the Early Roman period, the best parallels to our jars are provided by the products of Yodefat, a Jewish settlement destroyed by the Romans in AD 67 and never rebuilt, where pottery kilns were found. ${ }^{47}$ Allegedly, the same type of jars was being fired in two kilns discovered at Karm er-Ras site of Kafr Kanna (to the south-east of Yodefat and east of Sepphoris). ${ }^{48}$ The parallels to the jars of our Phases E-F (Roman period) come from Shikhin, ${ }^{49}$ while some jars comparable to those of Sha'ar-Ha Amakim Phase F were made in Ahihud. ${ }^{50}$ Actually, the kiln site of Ahihud pertained to the cluster of sites situated less than $10 \mathrm{~km}$ to the east of Akko, embracing also Yavor and Horbat Uza; all the three sites apparently began their activity as jar manufacturing centres in the Middle rather than the Early Roman period, that is, from the mid-second century AD on. ${ }^{51}$

\section{GROUP 3A (Fig. 5:1-3)}

Large bag- (sack-) shaped jugs, apparently intended for supplying and storing water; their body sherds or small fragments of rims may sometimes be mistaken for those of jars group 2a. Unlike those jars, however, they feature a pronounced neck. Such jugs at Sha'ar-Ha Amakim have been identified in the deposit of 'cistern' G/R. ${ }^{52}$ Visually, they are of similar fabrics as most of the jars in group $2 \mathrm{a}$. This vessel form originates in the local/regional ceramic repertoire of the Persian period, with examples attested both in the north and south. ${ }^{53}$ In the Hellenistic period, however, the production of this form of the vessels seems to have been limited to the northern coastal area. Apart from Sha'ar-Ha Amakim, this form of jug is still common in the Hellenistic layers at Tell Keisan ${ }^{54}$ and at Tel Dor, at the latter site occurring in a well-dated context of between 200 and 125 BC. ${ }^{55}$

\section{GROUP 3B (Fig. 5:4-5)}

Per analogiam to Hellenistic water jugs, these are the Roman-period jugs, apparently destined to carry water (dipper jugs), found in the deposit of Cistern D. Their fabric is comparable to that of the contemporaneous wine/olive-oil jars of our group $2 \mathrm{~b}$. Very thin-walled (almost 'egg-shell'), by their form they seem to be a distant development of storage jugs from 'cistern' G/R of pre-mid second century BC. They are not easy to be

${ }^{47}$ For the Yodefat type of jar, see: Avshalom-Gorni, Getzov 2002: 77, Fig. 5.1:4-7; Aviam 2014: 142, Fig. 5; 2015: 114 and 118; Avshalom-Gorni, Shapiro 2015: Fig. 10, no. 1a.

48 Aviam 2015: 118.

49 For the Shikhin type of jar, see Avshalom-Gorni, Getzov 2002: 77, Fig. 5.1:8-12, allegedly dated to AD 63-135; recently also Avshalom-Gorni, Shapiro 2015: Fig. 10, nos 3-3a.

${ }^{50}$ Avshalom-Gorni, Shapiro 2015: Fig. 10, no. 7 (type 'Uza 1a jar').

${ }^{51}$ See: Avshalom-Gorni, Shapiro 2015: 76-78 (the typology of the jars, see Fig. 10) and 80 (the discussion of the chronology).

52 Młynarczyk 2000.

${ }_{53}$ Młynarczyk 2009b: 100.

54 Briend, Humbert 1980, P1. 9:3-11.

55 Guz-Silberstein 1995: 308-309, type JG 11, Fig. 6.30:1 and 4. 

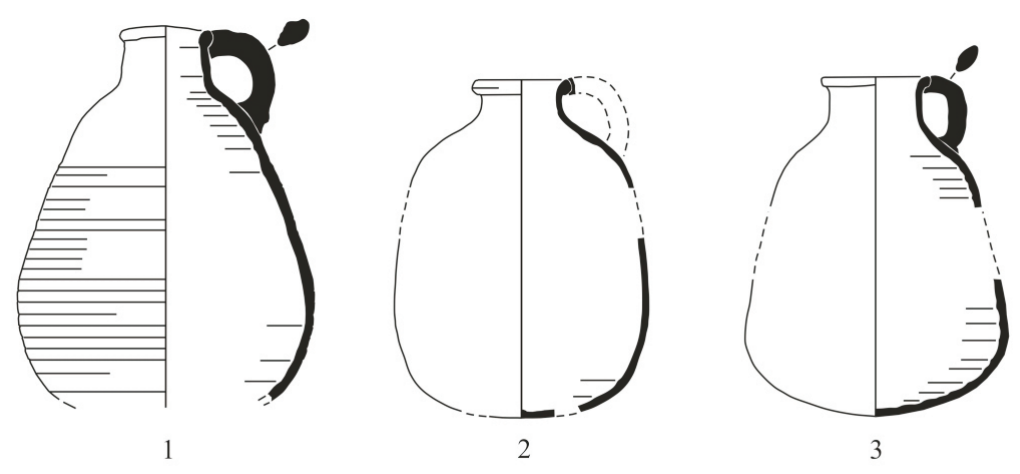

0
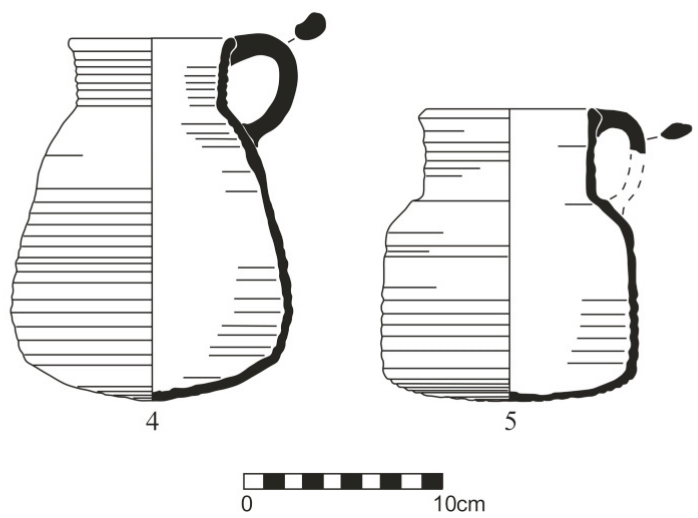

5. Examples of 'baggy' water jars from Sha'ar-Ha Amakim of the Hellenistic (1-3, group 3a) and Roman (4-5, group 3b) periods: 1 . inv. no. 889.5; 2. inv. no. 912.7; 3. inv. no. 889.4; 4. inv. no. 709.4; 5. inv. no. 735.5 (Drawing: M. Burdajewicz).

dated as only a couple of parallels are known from nearby sites such as Jalame, Sumaqa and Sepphoris. ${ }^{56}$

\section{GROUP 4}

Finally, also a few samples of other ceramics (marked as 'group 4') were chosen for the analyses on the assumption they might be diagnostic for a local/regional source of clay. They include fragments of ovens, raw clay pieces found close to one of the ovens, as well as a piece of a brick.

56 Jalame: Johnson 1988: 198-199, Fig. 7-42:619, erroneously described as a 'cooking pot with ribbed neck’; Sumaqa: Kingsley 1999: Fig. 9:23; Sepphoris: Tsuk, Rosenberger, Peilstocker 1996: P1. IX:5. 
Due to the usually small size of sampled fragments, in some cases it was not certain if a body sherd belonged, for example, to a jar (2a) or to a water jug (3a), or if a body sherd in the Phoenician semi-fine ware belonged to jar form 1a or 1b. Needless to say that with the body sherds, the shape of the vessels may have been uncertain, and when a small section of the rim is preserved, any closer identification of the jar's form is not possible either. Thus, some of the containers with a rim diameter bigger than that of average jars, may have been alternatively described as pithoi.

\section{THE GEOLOGICAL SETTING OF SHA'AR-HA AMAKIM}

Sha'ar-Ha Amakim is situated on the north-western slopes of the Lower Galilee foothills (14km south-east from Haifa, coordinates: 32॰43'22.79' N, 356'47.88' E), on a synclinal Qiryat Tiv'on Eocene block constituting the south-western part of the Lower Galilee hills (Fig. 6). In the south it is bordered by the Jezreel valley, in the south-west, a narrow Qishon river pass behind which rises the Mt Carmel ridge. The western border is the Zevulun Plain.

In this area the oldest sediments can be found in the Mt Carmel, Um el-Fahm and Lebanon Mountains anticlinoria. They represent dolomites belonging to the Albian Yagur Formation, covered by the Cenomanian-Turonian carbonates of the Judean Group. During the Senonian until the end of the Eocene uniform sedimentation of deep-sea chalks prevailed, locally with phosphates and some limestones in a local erosional unconformity.

Those deposits fill the Ramot Menashe (Galilee) and Bekaa (Lebanon) synclinoria, ${ }^{57}$ and belong to the Mount Scopus Group in Israel ${ }^{58}$ and the Chekka Formation in Lebanon. ${ }^{59}$ They are most exposed in the Lower Galilee foothills characterised by a gentle morphology. ${ }^{60}$

What attracts special attention in a search for ceramic material are green marls, green shales and argillaceous chalks with some phosphates of the Santonian - Early Campanian Kabri Member of the Menuha Formation, the white to yellow chalk and marls of the Campanian to Maastrichtian Ghareb Formation and the Paleocene to Early Eocene grey to green, partially bituminous marls of the Taqiye Formation. ${ }^{61}$

The Taqiye Formation is overlain by thinly-bedded Eocene chalks of the Avedat Group, Miocene-Pliocene coarse-grained, reddish, calcareous sandstone, sandy limestone, reddish clay and conglomerates of well sorted chert (Qurdani Formation), as well as poorly sorted conglomerates (Bet Nir Formation) of the Saqiye Group.

The Pliocene-Quaternary conglomerates, travertine, red sands, calcareous sandstone, dune sands, alluvia and soils belong to the Kurkar Group. ${ }^{62}$

${ }^{57}$ Cf. Kafri 1972; Sass, Bein 1982; Lipson-Benitah et al. 1997; Buchbinder et al. 2000; Bachmann, Hirsch 2006; Bentor 1966.

58 Flexer 1968.

59 Walley 1997.

${ }^{60}$ Levy 1983: 59.

${ }^{61}$ Generally used in the production of ceramics, cf. Bentor 1966: 72-73; Porat 1989; Goren 1995; Gilboa et al. 2006; Gorzalczany 2008: 83.

${ }^{62}$ Levy 1983; Sneh 2004; 2008; Segev, Sass 2009; Karcz, Sneh 2011. 
Calcareous sandstone "Kurkar"Quaternary

Quaternary alluvium / soil

Late Eocene-Pliocene clay, sandstone, marl and limestone

Miocene olivine basalts

Eocene chalk, limestone and chert

Cenomanian-Senonian alkali basalts and tuff

Senonian-Palaeocene chalk, marl, clay, chert and limestone

Cenomanian-Turonian limestone, dolomite and marl

Lower Cretaceous sandstone

marl and limestone

MEDITERRANEAN

SEA
6. Simplified geological sketch of study area (Drawing: J. Michniewicz; based on: Sneh, Bartov, Rosensaft 1998; Walley 1998: Fig. 2).

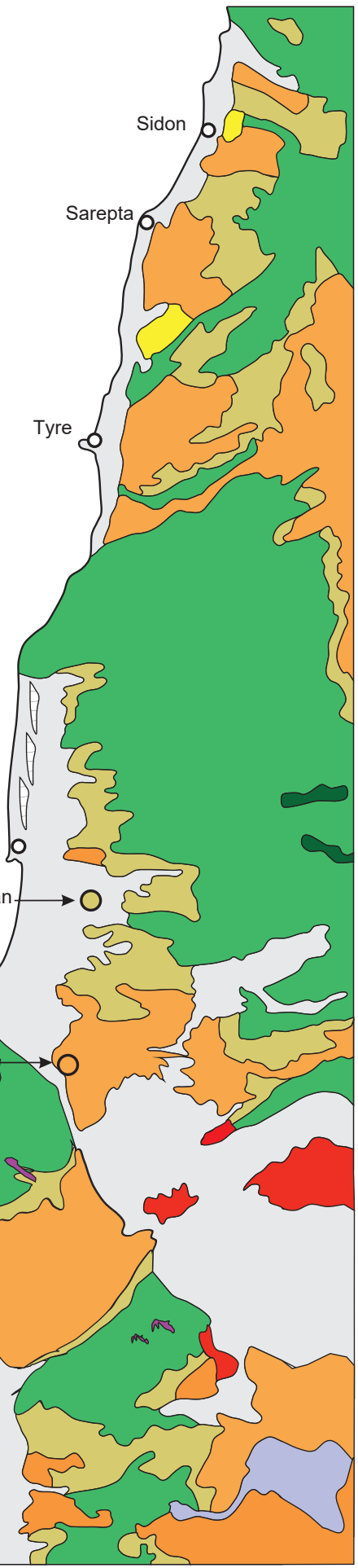


The coastal margin of the Zevulun Plain and the Galilean Coastal Plain is mostly covered by sand dunes composed of Nile-Delta quartz sands. ${ }^{63}$ They form Plio-Pleistocene and younger Pleistocene eolianite ridges, locally termed kurkar, which run parallel to the coastline, intercalated by red sandy loam soils locally termed hamra ${ }^{64}$ (there are also submerged kurkar horizons in the nearshore zone ${ }^{65}$ ).

What should be emphasised are differences in the mineral composition of Levantine beach sands, especially in the proportions of quartz and calcareous bioclasts. While the Nile-transported quartz is a component dominating on the beaches located south of Akko, northward of the site quartz disappears and calcareous components start to dominate. ${ }^{66}$

\section{VOLCANISM OF THE AREA}

Submarine volcanism was intensive from the Jurassic to the end of the Cretaceous period. Volcanic rocks are mainly tuffs and alkaline basalts.

In the Lower Cretaceous Hatira Formation, weathered fragments of Tayasir volcanic rocks can be observed. In the Mt Carmel and Um el-Fahm areas there are four Cretaceous magmatic/hyaloclastite outcrop horizons intercalated with carbonates: ${ }^{67}$ Early Cenomanian Kerem Maharal tuffs, the Middle Cenomanian Tavasim pyroclastics, Upper Cenomanian Makura, Me-Ammi pyroclastics, Shefeya lava flows and Senonian Bat Shelomo dark pyroclastics. The Cenozoic magmatism manifests itself in the Galilean outcrops as small Miocene intrusions (olivine/basalts/basanite). They are observed south and east of Qiryat Tiv $^{6}{ }^{68}$ in the foothills where a few Pliocene volcanic bodies of cover basalts represent the Bashan volcanic event. ${ }^{69}$

\section{THE STATE OF PETRO-ARCHEOLOGICAL RESEARCH ON JAR PRODUCTION IN GALILEE}

The petrographic and chemical research on the ceramics discovered in the Levant is conducted primarily in order to determine the places of their production and to identify trade routes. While the distribution of ceramic workshops in the Galilean area in the Roman period is relatively well known in archaeological terms, the Hellenistic period is one of the most poorly recognized in the coastal Levant and Galilee. ${ }^{70}$

\footnotetext{
63 Zviely et al. 2006; Elyashiv et al. 2015.

${ }^{64}$ Arabic word for 'red'. Sivan et al. 1999; Horovitz 1979: 100-108; Issar 1968; Bentor 1966: 1; Sneh 2008; Segev, Sass 2009; Ravikovitch 1969; Sneh, Bartov, Rosensaft 1998; Gvirtzman, Buchbinder 1978; Horowitz 1979: 84-88; Barzilay 2006.

${ }^{65}$ Cf. Zviely et al. 2007.

${ }^{66}$ Cf. Gilboa et al. 2006: 311; Cohen-Weinberger, Goren 2004; Landau, Goren 2004: 28-29.

${ }^{67}$ Bentor 1966: 105; Kaminchik et al. 2014: 116; Segev, Sass 2009; Segev et al. 2002.

${ }_{68}$ Miocene volcanic rocks extending mainly in south-eastern Lower Galilee and the Yizre'el Valley (Segev 2005).

69 Segev 2005; Levy 1983 (geological map).

70 Nitschke, Martin, Shalev 2011; Leibner 2009: 7.
} 


\section{Persian Period}

The finds of the Persian-period carinated-shoulder amphorae are abundant. Only in the southern Levant they have been found in at least 40 sites. $^{71}$ At the same time the number of kilns known from this period is small. They embrace the Persian-period kilns of Sarepta ${ }^{72}$ and a workshop in the south (the Sharon region), at Tel Michal. ${ }^{73}$

Bettles examined 307 thin sections of carinated-shoulder amphorae gathered from ceramic assemblages from 21 sites. ${ }^{74}$ The effect of this work was the distinction of two basic fabric classes (FC1 and FC2):

- fabric class 1 (four subclasses: 1A, 1B, 1C, 1D), characterised by a very fine, dense and highly calcareous matrix incorporating various quantities and genera of foraminifers of orange-red, red and brown colour, and

- fabric class 2 (four subclasses: 2A, 2B, 2C, 2D), characterised by a ferruginous silty matrix, with varying levels of carbonate matter. ${ }^{75}$

Predominant among those amphorae is FC1A, which the author describes as follows: macroscopically this fabric is characterized by moderate to sparse amounts of transparent and translucent well-sorted fine sand-size inclusions, moderate multi-chambered microfauna, and sparse blobs or streaks of red iron oxide of medium to coarse sand-size, cloudy pale yellow limestone of very coarse sand. Under microscope the matrix consists of a fine, dense, foraminiferous and ferruginous marl of clear orange colour with streaks of ferric oxide, Globigerinidae of Paleogene age, including Acarinina sp. ${ }^{76}$ Moreover, Bettles notes the presence of rare white mica flakes. ${ }^{77}$ Aplastic inclusions make up $2-5 \%$ of the volume. They consists predominantly of quartz and carbonate grains, with accessory minerals of hornblende, epidote, feldspar, chert and schist, as well as fragments of coralline algae, Amphiroa sp. ${ }^{78}$ She considers FC1A to be local to Sarepta on the basis of a comparison of the petrography of the amphorae discovered at the site with the local source - foraminiferous chalky Middle Eocene marls, the presence of local pottery workshops dated to the Late Bronze Age and the entire first millennium $\mathrm{BC},{ }^{79}$ and a comparison of the chemical composition of those amphorae to eleven pottery sherds from Sarepta previously analysed by Jan Gunneweg and others. ${ }^{80}$

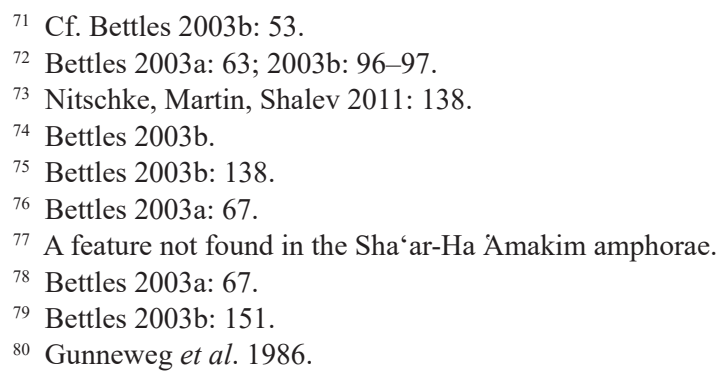


The next in terms of frequency is FC2A, characterised by a matrix reddish-brown in colour, ferruginous, silty and moderately calcareous, with sand-sized quartz accounting for up to $25 \%$ of the volume, which in Bettles' opinion is consistent with the hamra paleosol cropping out along the coastal region of Israel. ${ }^{81}$

The material of most of those fabric classes is of Paleocene-Eocene age, as indicated by the foraminifers it contains. Foraminiferous marls of Paleocene-Middle Eocene age are exposed along the Lebanese and north Galilean coast, between Sidon and Akko. ${ }^{82}$ That is why Bettles' FC1A, described by other scholars as 'Phoenician clay', need not come from the Sarepta region, because it was used at various times to produce all kinds of pottery since at least the Iron Age. ${ }^{83}$ However, worth emphasising is the distinctness of those marls from the older horizons of lithologically similar rocks, especially Paleocene Taqiye marls and Senonian marls, identifiable by the presence of foraminifers. ${ }^{84}$

\section{Hellenistic and Roman Periods}

The material of jars made in the Hellenistic period in Galilee and adjacent areas was examined by Yardenna Alexandre. ${ }^{85}$ Hellenistic pottery kilns are known from Karem el-Ras (near today's Kefr Kanna). ${ }^{86}$

In an extensive study of common pottery from nineteen excavated sites in the Galilee and Golan, David Adan-Bayewitz and Moshe Wieder ${ }^{87}$ demonstrated that in the Roman period common pottery was mainly made in three manufacturing centres of Lower Galilee: Kefar Hananya (specialising in cooking pottery), Shikhin, and Yodefat ${ }^{88}$ During the Early Roman period a large-scale production of jars took place in Shikhin and probably also in many smaller, so far unknown, local workshops, as shown by the discoveries of kilns in Yodefat.$^{89}$ In Yodefat (situated on an outcrop of Cenomanian dolomites) two pottery workshops were discovered containing four kilns, the waste of cooking ware and storage jars..$^{90}$ In Shikhin, which was a major supplier of storage jars, the vessels were made of one of the three soil types: colluvial-alluvial soils, brown grumusols, or pale rendzinas. At Yodefat

\footnotetext{
${ }^{81}$ Those conclusions are corroborated by Gorzalczany's (2006) later study of Persian-period vessels found in the kilns of Tel Mikhal and amphorae discovered at Horbat Malta which, according to Gorzalczany (2008), were made of a mixture of terra rossa and rendzina soils rich in nummulitic chalk.

82 Cf. Sneh, Bartov, Rosensaft 1998; Bettles 2003a: 148-149. Bettles considers in detail other potential sources of those marls, but she points out that they lie many kilometres away from the coast.

${ }^{83}$ Cf. Cohen-Weinberger, Goren 2004; Stager 2011: 58, 101; Gilboa, Waiman-Barak, Jones 2015: 374.

${ }^{84}$ Cf. Sneh, Bartov, Rosensaft 1998; Beydoun 1977: 332.

${ }^{85}$ Alexandre 2013: 14-15.

${ }^{86}$ Cf. Aviam 2014: 140-142.

${ }^{87}$ Adan-Bayewitz, Wieder 1992; Wieder, Adan-Bayewitz 1999. Cf. also Adan-Bayewitz 1993.

88 Significantly different are also the ceramics produced in the Golan region.

89 Wieder, Adan-Bayewitz 1999; Berlin, Frankel 2012.

${ }^{90}$ Cf. Wieder, Adan-Bayewitz 1999: 329; Adan-Bayewitz, Aviam 1997; Aviam 2014.
} 
the remains of a pottery kiln and waste are dated to the Early Roman period. This pottery group is composed of reddish-yellow carbonate rendzina soil mixed with much less calcareous clayey red soil. ${ }^{91}$ In Shikhin no tempering admixture was used, and in Yodefat highly calcareous rendzina was enriched with an addition of terra rossa. ${ }^{92}$

Ceramic kilns also operated in Ahihud, a few kilometres east of Horbat Uza (Khirbet Aiyadiya), ${ }^{93} 4 \mathrm{~km}$ north-east of Tell Keisan. The ceramics discovered at that site (common pottery and jars) were made of at least four varieties of material described as: (1) terra ross $a$ and ferruginous ooliths assigned to Kefar Hananya workshops; ${ }^{94}$ (2) terra rossa and sand of a yellowish brown silty matrix and quartz sea sand, assigned as local to Ahihud workshops; ${ }^{95}$ (3) terra rossa and carbonate material, composed of terra rossa and calcareous streambed sand; and finally (4) non-homogeneous clay and terra rossa pellets made of calcareous rendzina - soil rich in reddish oval pellets of different size and distinct silty texture. Sometimes the pellets are dark grey to black, having been fired in reducedoxygen conditions in the kiln. The clay paste of group 3, compared with group 2, was less levigated. In the opinion of the authors, some of those vessels could be copies of Shikhin technology; storage jars made of this material are characterised by a thick grey core and relatively thin edges in the cross-section.

They match the Yodefat group of pottery described by Wieder and Adan-Bayewitz, probably produced locally in Ahihud. ${ }^{96}$

\section{RESULTS OF PETROGRAPHIC STUDIES}

Comparative petrographic analyses of 154 specimens were performed. Each sample was described macroscopically and documented photographically using an Olympus SZX-9 binocular. Polished petrographic preparations were made of each fragment by embedding them in epoxy resin. The study was made in transmitted light complemented with observations in reflected light using an Olympus AX70 Provis petrographic microscope. Microscopic studies were conducted to establish the mineral composition and petrographic features of aplastic components and the matrix, including the temperature of its firing. Minerals hard to identify optically were examined by X-ray diffraction (XRD), their chemical composition being determined using the Energy-dispersive $\mathrm{X}$-ray method (EDX). To determine the age of the material, each polished section was examined micro-paleontologically. This study was carried out by Prof. Barbara

91 Cf. Aviam 2014; Wieder, Adan-Bayewitz 1999: 339.

92 Cf. Wieder, Adan-Bayewitz 1999: 329; Adan-Bayewitz, Aviam 1997; 2014.

93 Cf. Avshalom-Gorni, Shapiro 2015.

94 The authors claim the presence of ferruginous ooliths to be evidence of the connection of the material with the Lower Cretaceous rocks near Kefar Hananya, which is hard to accept because landforms of this type are a common effect of laterite weathering, cf. e.g. Jones 1965.

95 According to the authors, the same material was used in Horbat Uza.

96 Wieder, Adan-Bayewitz 1999; Avshalom-Gorni, Shapiro 2015: 82. 
Olszewska from the Institute of Geological Sciences, Polish Academy of Sciences in Cracow.

The examined specimens are listed in Tab. 1. Eleven samples, which have not been assigned to any petrographic group, are omitted from the present discussion.

The conducted examination allows to distinguish at least eight petrographic groups (henceforth: PG) of ceramics, the most important including:

PETROGRAPHIC GROUP I.A - 'ALGAE'

\section{SUBGROUP I.A1 (Fig. 7:1)}

Eocene foraminiferous 'light' marl with sparse algae, chalk rich in ferruginous-globigerina ooze, 5-8\% quartz sand +/- minute red soil balls.

Specimens: ${ }^{97}$ SA-2, SA-6, SA-8, SA-11, SA-13, ${ }^{98}$ SC-39, SC-41, ${ }^{99}$ SD1-62, SD1-67, SD2-71, SE-86, SFx-115, SX-119, SA-126, SX-129, SX-135, SX-143, SX-146.

A group of ceramics light red in colour (5YR 7/6), mostly fired slightly silty on the surface. They were made of foraminiferous marl locally coloured by iron oxides, tempered with a 5-8\% admixture of sand. On optical examination the matrix (groundmass) is light, yellow-brown or light-orange, in places of concentration of iron and manganese oxides red or opaque. In most samples the matrix is optically active, which is indicative of a low temperature of firing, $650-700^{\circ} \mathrm{C}$. Only samples SA-2, SA-126, SX-129, and SX-135 were fired at a higher temperature, the result being the anisotropy of their groundmass.

A diagnostic feature of the groundmass is the presence of well-preserved, abundant Middle-Late Eocene microfauna: Chilogumbelina sp. and Globigerina ex gr. praebulloides-officinalis, less commonly Tenuitella sp. and Uvigerina sp., and also numerous, though of no major stratigraphic significance, Globigerina sp., Brizalina sp., and radiolarians of the genus Spumellaria. Their shells are either scattered throughout the matrix or form local clusters (this especially holds for Globigerina), which is usually accompanied by a concentration of iron and manganese oxides. ${ }^{100}$ The clasts embedded in the groundmass, often of ferruginous chalk, vary in size and shape. They are usually more or less oval, and

\footnotetext{
97 The particular elements of sample' symbols refers to Sha'ar-Ha Amakim (S), phase according to the site stratigraphy, and number of the sample.

${ }_{98}$ What distinguishes sample SA-13 from the other representatives of PG I.A1 is the higher, 15\%, content of the sandy admixture.

99 Samples fired in reduced-oxygen conditions.

${ }^{100}$ It is a debatable question whether the chalk clasts rich in iron and Globigerina are an integral part of the material used or are an admixture intentionally made and added by the potter.
} 
their boundaries are fuzzy; less frequent are clasts a few millimetres in size with sharp, irregular contours and sharp boundaries.

The content of silt-sized quartz particles is low (under 5\% of the volume), some of the samples are almost completely devoid of them.

The temper consists of irregularly scattered grains of fine sand-sized quartz $(0.1-0.25 \mathrm{~mm})$ accounting for $5-8 \%$ of the volume. It is well sorted, only a few grains are larger, $0.3-0.4 \mathrm{~mm}$ in diameter. In sample SA-126 the admixture has a different composition. The sand grains it contains are quartz-carbonates in the 50:50\% proportion. Carbonate grains that are micritic in structure are coarser and partly decomposed as a result of firing.

Quartz is mostly monocrystalline, moderately rounded, less frequently unrounded (subangular-subrounded). Its crystals show uniform extinction (volcanic grains) and undulose extinction (metamorphic grains). A few grains of polycrystalline quartz are certainly of metamorphic origin. Feldspars appear sporadically; they are both, polysynthetically twinned plagioclases and potassium feldspars distinguishable optically, especially when the twinning is cross-hatched. There are also single grains of chert with a characteristic mosaic structure, and heavy minerals, mostly rutile, apatite and green pleochroic amphibole. Titanomagnetite predominates among the numerous opaque minerals.

\section{The PRESENCE of AMPHIROA SP.}

A characteristic feature of this group is the presence of single fragments of red algae of the family Corallinaceae, especially Amphiroa sp. They can be identified on the basis of their structure: an alternate arrangement of layers composed of long and short cells. The alga fragments are of a fine- and a medium-sand fraction, often angular in shape, appear regularly though in small numbers, apart from sample SA-126.

Their presence among the remaining numerous microorganisms gives the impression that they are a natural component of the marl employed. However, as Binyamin Buchbinder ${ }^{101}$ demonstrated, Amphiroa start to be common from the Pleistocene to the present. They can be found in bioclastic sediments distributed along the Coastal Plain and in the foothill areas in Neogene formations. Today their remnants are common in the beach sand north of Haifa along the Israeli and Lebanese coasts. Considering the Eocene age of the material established micro-paleontologically, the Amphiroa fragments it contains seem to be a component added with quartz sand. ${ }^{102}$

\section{ANALOGIES}

The descriptions of ceramics from several south Levantine sites are almost analogical: Tyre, Sarepta, Akko, Ashkelon, Atlit, Gil'am, Tell el-Hesi, Yoqne'am, Tell Keisan, ${ }^{103}$ Sidon, ${ }^{104}$

\footnotetext{
101 Buchbinder 1975.

102 Cf. Eliyahu-Behar et al. 2008: 2899; Gorzalczany 2006: 59; 2008: 83; Bettles 2003a; 2003b; Landau, Goren 2004: 28.

103 Cf. Bettles 2003a; 2003b.

104 Cf. Bettles 2003a; 2003b; Griffiths 2003: 18-19.
} 
Horbat Malta, ${ }^{105}$ Tel Dor, ${ }^{106}$ Ashdod,${ }^{107}$ Gamla, ${ }^{108}$ and the Iron Age Phoenician ceramics of Kommos, Crete. ${ }^{109}$

\section{SubGROUP I.A2 (Fig. 7:2)}

Eocene foraminiferous 'light' marl + red soil balls + quartz sand (devoid of ferruginous globigerina ooze).

Specimens: SBc-15, SDc-51, and SA-127.

The fabric of PG I.A2 is macroscopically similar to that of the ceramics of PG I.A1, light orange (7.5YR 8/6) and light red in colour (2.5YR 7/6-8), with similar petrographic features and micro-paleontological composition. What makes it fundamentally different from the ceramics of PG I.A1 is the absence of foraminiferous iron oxides, replaced here by an admixture of ferruginous red type soil (terra rossa).

\section{ANALOGIES}

Tel Michal, ${ }^{110}$ Iron Age Phoenician ceramics from Kommos, Crete. ${ }^{111}$

\section{Subgroup I.A3 (Fig. 7:3)}

Eocene foraminiferous 'light' marl + red soil balls + quartz sand + hyaloclastite fragments.

Specimens: SBc-35, SD1-66, SD2-72, SE-101, ${ }^{112}$ SFx-112, SF-124, SD1-125, SE-134.

A group of pottery petrographically similar to PG I.A1 and especially to PG I.A2. What makes it different is the presence of single honey-yellow hyaloclastites.

Sand-sized glassy 'yellow fragments' irregularly translucent, fragmentarily argillitised, honey-brown in colour, usually characterised by sharp boundaries, sometimes with polygonal e.g. hexagonal contours. Therefore, it cannot be excluded that some of them can represent pseudomorphs of garnet(?), pyroxene(?), amphibole, or olivine.

The identification of the above phases was also made using the XRD method. In spite of the removal of carbonates, this study ruled out the presence of iddingsite and did not confirm the presence of minerals from the group of pyroxenes, amphiboles, olivines and

\footnotetext{
105 Gorzalczany 2008.

106 Gilboa, Cohen-Weinberger, Goren 2006: 310-311; Eliyahu-Behar et al. 2008: 2899.

107 Cohen-Weinberger 2013: 123-124.

108 Berlin 2006: 16.

109 Gilboa, Waiman-Barak, Jones 2015: 82, Fig. 3.

${ }^{110}$ Gorzalczany 2006: 59.

111 Gilboa, Waiman-Barak, Jones 2015: 80-81.

112 Containing no quartz, fired in reduced-oxygen conditions?
} 
garnets. At the same time there was a slight elevation of the groundmass, corroborating the presence of the glassy phase.

Thus, it is hard to decide unequivocally what the 'yellow fragments' are. What speaks for a hyaloclastic origin of those particles is the presence of submarine tuffs among rocks of Mt Carmel, and especially the nearby Sha'ar-Ha Amakim outcrops of Tayasir tuffs.

What attests to the volcanic origin of those particles is also the presence of scattered fine crystals of unaltered pyroxene, amphiboles and 'fresh' feldspars. Automorphism and no signs of any transformation of those minerals also suggest their volcanic origin. ${ }^{113}$

\section{ANALOGIES}

Iron Age Phoenician ceramics from Kommos, Crete, ${ }^{114}$ Tel Dor, ${ }^{115}$ Yoqne'am, Amarna tablets, ${ }^{116}$ Megiddo. ${ }^{117}$

\section{PETROGRAPHIC GROUP II}

Red soil, silty clay, almost devoid of a sand-sized admixture.

This fabric is iron-rich; it contains an abundant amount of fine, silt-sized quartz or carbonates and taxonomically different foraminifer groups. Their age and the macroscopic similarity of shells served to distinguish following subgroups.

\section{SubGROUP II.A (Fig. 7:4)}

Paleogene foraminifers: silty rendzina soil.

Specimens: SBc-22, SDc-50, SDc-54, SDc-57, SOV-137'. ${ }^{118}$

This is the most distinct subgroup. It contains a set of five thin-walled sherds fired to a light-red colour (2.5YR 6/8-7/8) and a fragment of the wall of an oven, SOV-137'.

On optical examination the matrix of the vessels is light red or light brown, depending on the level of oxidation, inactive in samples SDc-50, SDc-57 and SDc-54. The presence of numerous dark red oval infillings is probably an effect of clay mixing (but the activity of earthworms cannot be ruled out). ${ }^{119}$

The raw material is extremely lean, rich in quartz silt, which accounts for $30-40 \%$ of the volume. It is made up almost exclusively of particles of Eolian quartz, there are also

${ }^{113}$ Cf. Cohen-Weinberger, Goren 2004: 9.

114 Gilboa, Waiman-Barak, Jones 2015: 85, Fig. 6.

115 Cf. Eliyahu-Behar et al. 2008: 2901 ('Group 5').

116 Goren, Finkelstein, Na'aman 2004: 252-254, Fig. EA259.

117 Arie, Buzaglo, Goren 2006: 560.

118 Fragment of the wall of the oven, used for comparison.

119 Cf. Koistra, Pulleman 2010. 
accessory grains of feldspar, oxidised amphibole and fine pedogenic(?)/pyroclastic(?) 'red fragments'.

The sand-sized admixture consists of single oval grains of micritic limestone (especially in SDc-50), sporadically one can also find sand-sized quartz, feldspars and pyroxenes. Notable is the presence of single ferruginous (iron-manganese?) ooliths.

In spite of the sintering of the groundmass, some foraminifer associations have remained in the samples: Acarinina cf. alticonica Fleisher, Acarinina sp., Chiloguembelina sp., Globigerina sp., and Paragloborotali aff. nana (Bolli), dating the association to the Paleogene, most probably the Eocene. Since the rendzina soil found in the Sha'ar-Ha Amakim region has developed on Eocene chalk, this can be a group of vessels produced locally.

The Eocene is also the age of the sample of the wall of an oven SOV-137, petrographically similar to the other samples in this subgroup (the same content of quartz silt, the presence of just a few sand-sized grains of limestone, and opaque ferruginous ooliths). Unlike the vessels of PG II.A, perhaps because of a different function, this oven fragment contains numerous grass remnants; it also shows a much lower degree of sintering.

\section{SubGROUP II.B (Fig. 7:5)}

Cretaceous foraminifers: silty soil + chalk rich in Globigerinelloides.

An alternative name of the group: rendzina(?) soil - Cretaceous parent rock age.

Specimens: SC-36, SDc-44, SD1-64, SD1-69, SD2-76, SD2-77, SD2-79, SD2-80, SE-87, SE-92, SE-98, SE-99, SF-106, SF-107, SX-142, SX-148, SX-151, SOV-250.

Ceramics made of clay rich in calcite-quartz silt, with some clasts of chalk rich in Globigerinelloides and additions of terra rossa balls. Most vessels of this group: SC-36, SDc-44, SD1-64, SD1-69, SD2-79, SD2-80, SE-87, SE-98, SE-99, SF-107, SX-148, SX-151, and SOV-250, are light red on the surface and dark steel-grey on the fracture. Samples that differ in colour are SD2-76, SD2-77, SE-92, SF-106, and SX-142 - with a pale brown outer surface (10YR 8/3), a grey core, and a brown inside (5YR 6/4-5YR 6/3).

Especially significant is the presence of irregular clasts of light-grey chalk rich in Globigerinelloides. It is possible that they are fragments of the parent rock on which the examined soil has developed. A characteristic feature of the entire association is the presence of opaque ferruginous ooliths.

The composition of the foraminifer associations preserved in the ceramics: Globigerinelloides sp., Hedbergella sp. and Heterohelix sp., sets the age of the material at Upper Cretaceous. 


\section{SubGROUP II.C (Fig. 7:6)}

Cretaceous foraminifers: soil rich in carbonate silt (no chalk).

Specimens: SDc-46, SDc-47, SD2-73, SD2-75, SD2-81, SD2-83, SE-96, SF-110, SFx-118, SX-144, SX-147.

Those are ceramics similar to PG II.B, but with no chalk clasts. Besides, the chief aplastic component is carbonate silt (prevailing over quartz silt in terms of quantity). The microfauna found in samples SDc-46, SDc-47, SD2-73 and SD2-75: Globigerinelloides sp., Globigerinelloides aff. bolli Pessagno, Hedbergella sp., and Heterohelix sp., determine the age of the material at Late Cretaceous.

\section{SubGROUP II.D (Fig. 7:7)}

Soil rich in calcareous silt (unknown age of parent rock).

Specimens: SDc-42, SDc-43, SDc-45, SDc-49, SDc-52, SDc-53, SDc-55,SDc-56, SD2-84, SD2-85, SE-89, SE-91, SE-93, SF-103, SF-104, SD1-121, SX-141, SX-145.

A set of vessels produced from material with an elevated content of calcareous silt and a small proportion, or absence, of a sand admixture with signs of pedogenic changes. The state of preservation of the microorganisms makes it impossible to determine the geological age of the material.

ANALOGIES FOR SUBGROUPS II.A-D

Shikhin, ${ }^{120}$ Horbat Uza and Ahihud, ${ }^{121}$ Tel Michal, ${ }^{122}$ Persian-period Horbat Malta. ${ }^{123}$

\section{PETROGRAPHIC GROUP III (Fig. 7:8)}

Cretaceous dolomitic marl.

Specimens: SE-94, SE-97, SF-102, SF-105, SF-108, SFx-113, SFx-114, SFx-117, SFx-149, SX-150.

This is a group the fabric which stands out for the very high content of fine rhombohedral crystals of dolomite. Those are amphorae with a light red sherd (2.5YR 6/8), massive, only

\footnotetext{
${ }^{120}$ Cf. Adan-Bayewitz, Wieder 1992: 198-199; Wieder, Adan-Bayewitz 1999: 335-338.

121 Avshalom-Gorni, Shapiro 2015: 80-83.

122 Gorzalczany 2006: 60-61.

123 Gorzalczany 2008: 82-83.
} 
sample SX-150 is light brown (5YR 6/6), as well as more lightly fired and slightly weathered. Their matrix is composed of dolomitic marl, light red and yellow in plane-polarized light (henceforth PPL), light brown in partly reduced fragments.

The argillaceous minerals of the groundmass have remained optically active in samples SE-97, SF-102, SF-105, SF-108, SFx-117, and residually active in samples SE-94, SFx-113, SFx-114, SFx-149, SX-150, thus reflecting the different temperatures of firing.

Dolomite crystals are silt-sized or fine-grained sand, $0.01-0.13 \mathrm{~mm}$, usually automorphic, accounting for $40-60 \%$ of the volume.

The material of samples SE-97 and SF-108 is enriched with an admixture of terra rossa containing some quartz silt. The red silty soil of terra rossa is distributed in the form of stains and fine balls. The other vessels of this group contain just a few fragments of ferruginous argillaceous shales devoid of quartz silt.

Aplastic inclusions can be observed in the form of single bits of dolomitic rock; their content is higher in samples SF-102, SF-105 and SFx-114.

Most species found in the polished sections of this group are indicative of the Late Cretaceous, i.e. younger than the Albian: Hedbergella sp., Heterohelix sp., single Globigerinelloides. In the case of sample SF-102, the presence of Guembelitria aff. cretacea Cushman gives the age of the material as not older than the Santonian.

\section{ANALOGIES}

Chalcolithic ceramics, ${ }^{124}$ Amarna tablets, ${ }^{125}$ Late Bronze Age Ashdod, ${ }^{126}$ Bet-She'an, ${ }^{127}$ Persian-period Tel Michal. ${ }^{128}$

\section{PETROGRAPHIC GROUP IV}

'Creamy pottery': chalky marl of varied age + terra rossa balls or ferruginous argillaceous shale.

A group of fragments of amphorae with creamy-white sherds (10YR 8/3-5YR 8/4), slightly darker on the fracture, sometimes light beige (10YR 7/3-6/3). They are made of highly calcareous marl containing abundant foraminifers, some terra rossa balls, or ferruginous argillaceous shale fragments.

Predominant among the microorganisms are foraminifers, indicating the age of the material to be Cretaceous and Paleogene. Their state of preservation differs; what has been left of them is often only fine, grey-golden clusters of micrite and voids.

\footnotetext{
124 Cf. Goren 1995: 291.

125 Cf. Goren, Finkelstein, Na'aman 2004: 262-263.

126 Cohen-Weinberger 2013: 124.

127 Cohen-Weinberger, Goren 2011: 218-219.

${ }^{128}$ Gorzalczany 2006: 61.
} 
The colour of the matrix in transmitted light depends on the content of terra rossa and the reduction level of a sherd. Usually it is grey-olive with a hint of red pigmentation. Differences in the temperature of firing are reflected in the variously preserved optical activity of argillaceous minerals. Terra rossa occurs as an admixture in the form of dark red points or irregular streaks and spots.

In some samples there are grey, isotropic oval balls of high micro-porosity. Those are fragments of a red soil in which iron has undergone reduction, and minerals - partial melting. What indicates such an origin of those clasts is the locally preserved red colour, the presence of silt-sized quartz and micro-oolitic pedogenic structures (the reduction process has not been completed). It cannot be ruled out that some of those grains are fragments of tephra.

Both the percentages of the above-mentioned components and the petrographic composition of the aplastic admixture vary. In this context we observe especially great similarities among the following subgroups of vessels:

\section{SUBGROUP IV.A (Fig. 7:9)}

Late Paleocene-Eocene chalky marl, red soil admixture.

Specimens: SA-1*, ${ }^{129}$ SA-3, SA-7, SBc-21*, SD1-59, SD1-61.

The material devoid, or almost devoid, of a sand-sized admixture (SA-3, SD1-61 - sandsized quartz accounting for less than $3 \%$ of the volume).

\section{SubGROUP IV.B (Fig. 7:10)}

Eocene chalky marl + large clasts of isotropic levigated red soil.

Specimens: SBc-23, SBc-25, SC-40.

The matrix contains numerous clasts of red soil $(0.2-2.0 \mathrm{~mm}$ in diameter) and clasts of grey foraminiferous chalk. Together those components make up c. $15 \%$ of the volume. Occasionally one can find transparent, colourless sand-sized particles of the glaze as well as single automorphic feldspars. What characterises this subgroup is the absence of quartz in the form of the silt or sand fraction.

\section{SubGroup IV.C (Fig. 7:11)}

Chalky marl of unknown age + amorphic red clayey shales $+5-8 \%$ of fine quartz sand.

Specimens: SA-10, SBc-16, SD1-65.

129 (*) specimens containing few reduced terra rossa pellets. 
Ceramics similar to PG IV.B, but with 5-10\% of quartz silt and an admixture of quartz sand making up $5-7 \%$ of the volume. Its characteristic feature is also the presence of numerous argillaceous red shales, amorphic slag, and a small admixture of quartz silt $(<2-5 \%$ of the volume). Sample SA-10 contains a glaze clast. The absence of preserved foraminifers makes it impossible to determine the age of the material.

\section{SUBGROUP IV.D (Fig. 7:12)}

Paleogene marl $+5-8 \%$ quartz sand.

Specimens: SA-5, SA-9, SBc-26, SBc-34, SC-37, SD2-74, SE-90, SA-120.

Those ceramics are similar to PG IV.A, but they contain 5-8\% of fine-grained quartz sand. In most samples there are relatively few variously shaped 'black fragments' which are pellets of black tephra or red soil darkened in reduced-oxygen conditions. The presence of single specimens of foraminifers Pseudohastigerina sp. and Chiloguembelina sp., and of relatively numerous Globigerina sp. is indicative of the Paleogene (Eocene?).

\section{SUBGROUP IV.E (Fig. 7:13)}

Cretaceous marl + amorphic clayey soil or slag $+5-8 \%$ fine quartz sand.

Specimens: SBc-24, SBc-28, ${ }^{130}$ SBc-33, SOV-139.

Macroscopically, ceramics of creamy colour (7.5YR 8/4) with numerous black pellets of black-reduced red soil, sometimes containing pedogenic ferruginous ooliths. The presence of Hedbergella sp., Heterohelix sp. and Globigerinelloides sp. sets the age of the material at Late Cretaceous.

The sample SOV-139 from a kiln is made of a material similar to that of PG IV.E. It is fired to a light-creamy colour. On optical examination its matrix is light yellow. It was made of calcareous marl containing an admixture of chalk. The composition of the preserved foraminifers: Globigerinelloides aff. bentonensis (Morrow), Heterohelix aff. moremani (Cushman), Hedbergella sp., and Hedbergella aff. infracretacea (Glaessner) as well as the presence of fairly numerous cross-sections of very small plant fragments (charophytes?) put the age of the material at Late Cretaceous (not older than the Albian because of the presence of the genus Heterohelix).

${ }^{130}$ Because of the absence of microorganisms preserved in the material, it can be from the Eocene age and belong to the technologically similar PG IV.B. 


\section{SubGroup IV.F (Fig. 7:14)}

Eocene marl with mica particles.

Specimen: SE-100.

SE-100 stands out for the presence of numerous fine lamellae of mica, oxidised biotite, and colourless muscovite. The preserved microfauna: Angulogerina sp., Globigerinoides sp., Tenuitella sp, Brizalina sp., Globigerina sp., and Lingulina sp., indicate the Eocene period as the age of the material.

Subgroup PG IV.G, distinguished for the jars from Tell Keisan, will be published separately. ${ }^{131}$

\section{SubGROUP IV.H (Fig. 7:15)}

Grey-fired ceramics with features of PG I.A1.

Specimen: SA-7.

Macroscopically buff, pale yellow (2.5Y 8/2), on optical examination its matrix is mostly amorphic, grey with a touch of green, locally coloured with iron compounds to brown-red, usually black. This pigmentation goes with accumulations of microfauna, especially Globigerina sp. There are also streaky chalk clasts of fuzzy contours, slightly de-pigmented when compared with the matrix, containing single shells of Acarina sp., the presence of which sets the age of the material at Late Paleocene/Eocene.

There are very few sand-sized grains, less than $5 \%$ of the volume. Those are grains of micritic limestone, perhaps bioclasts and monocrystalline medium-sand quartz. Also present are single cherts.

The above characteristics, especially the pigmentation with iron compounds clustered around Globigerina, make this material similar to PG I.A1 ceramics, but fired in reduced-oxygen conditions.

ANALOGIES FOR SUBGROUPS IV.A-F, H

Yodefat(?), ${ }^{132}$ Mamluk-period Khirbat Din'Ila, ${ }^{133}$ Yoqne'am, Tell Keisan, Akko, Tell Abu Hawam.

\footnotetext{
131 Michniewicz, Młynarczyk in preparation.

132 Cf. Wieder, Adan-Bayewitz 1999: 338-339; Avshalom-Gorni, Shapiro 2015: 83-84.

133 Shapiro 2014: 110, Fig. 5.
} 


\section{PETROGRAPHIC GROUP V (Fig 7:16)}

Amorphic granular/dense calcareous marl + terra rossa balls + volcanic component $+15 / 20 \%$ quartz/Ca sand - high temperature of firing.

In terms of the colour of sherds, the samples can be divided into two subgroups:

- cream-beige in colour: SA-12, SBc-14, SBc-17, SBc-18, SC-38, SD1-58, SD1-60, SOV-249, and

- bright orange in colour: SA-4, SBc-27, SBc-29, SBc-30, SBc-31, SBc-32, SD1-133.

The whole group has a micro-granular structure disappearing with an increase in the sintering of the groundmass.

The cream-beige vessels are creamy on the surface $(2.5 \mathrm{Y} 8 / 3)$ and beige on the fracture (10YR 7/3). The bright orange group is light red (5YR 6/4), which is due to an elevated content of dispersed red soil or a lower degree of reduction of the iron compounds that it contains. The remaining set of petrographic features is similar to those of the cream-beige subgroup.

The matrix is composed of highly calcareous marl, in PPL dark grey, greenish grey in convergent light, optically inactive apart from carbonates. Its micro-porosity is high and takes the form of tiny vermiform fractures.

The characteristic features include fragments of light grey marly shales varying in size and shape, clasts of chalk rich in fine microfossils (Globigerina?), and pellets or streaks of dispersed clayey ferruginous soil.

Fine golden carbonates scattered in the groundmass give it a pseudo-granular structure; they are remnants of decomposed microfauna. At a high temperature they disappear, entering into a reaction with argillaceous minerals.

Iron compounds included in marl and the admixture of red soil underwent reduction and sintering. As a result, its pellets turned black. The small oval voids present in those pellets make them similar to pyroclastic.

The group stands out for its substantial sand admixture (15-25\% of the volume). Quartz predominates (over 80\%), mostly in its monocrystalline form in the $0.08-0.55 \mathrm{~mm}$ fraction. It is variably rounded - usually subangular-subrounded, its grains showing both undulose and uniform extinction. The proportion of polycrystalline quartz is small - those are fragments of metamorphic shales and quartzitic limestones.

Sand-sized carbonates have undergone decomposition; today they form irregular clusters of secondary micrite. The remains of calcareous skeletons are numerous very fine oval voids.

Secondary components of the temper include feldspars, usually fresh and polysynthetically twinned, one can also find specimens with a laminar structure (plagioclases) and twinned in a cross-hatched pattern.

Also characteristic is the presence of glassy 'yellow fragments' which, like terra rossa, mostly turned black. The yellow-honey colour of those clasts is then visible only on their margins. On examination, their chemical composition shows the presence of silica, aluminium, magnesium and a few percent of calcium, which is close to the 
composition of pyroxenes. Other particles are much more complicated in structure and composition.

Accessory components are colourless sand-sized pyroxenes, fine, yellow, orange-oxidised and green amphiboles, particles of colourless glaze, and crystals of dark-orange rutile.

The age of the material is hard to determine because of the high temperature of firing. The identifiable foraminifers have only been preserved in samples SBc-18, SBc-30 and SD1-133. Those are mostly Globigerina sp., Chiloguembelina sp. and Angulogerina sp., making the Eocene the probable age of the material. In turn, sample SA-4 contains single Heterohelicidae, which can put its age at Cretaceous.

\section{ANALOGIES}

Not known.

\section{PETROGRAPHIC GROUP VI (Fig. 7:17)}

Red sandy soil (hamra).

Specimens: SDc-48, SA-123.

Two vessels of dark-red colour (2.5YR 5/6) with dull-red, ferruginous matrix, inactive in PPL, of varied amounts of quartz silt, rich in the sand fraction $(0.1-0.3 \mathrm{~mm})$ accounting for $30-40 \%$ of the volume. Sand grains are mostly (95\%) monocrystalline quartz, showing both uniform and undulose extinction; the remaining 5\% includes K-feldspars and plagioclases, some heavy minerals, chiefly amphiboles, and sparse cherts. The samples are identical to hamra soil occurring in the Haifa region.

\section{ANALOGIES}

Tel Dor (petro-group 4) ${ }^{134}$ Kommos, Crete, ${ }^{135}$ Ashdod Fort, Ashkelon, Atlit, Tel Megadim. ${ }^{136}$

\section{PETROGRAPHIC GROUP VII (Fig. 7:18)}

Dolomitic silt, rich in 'red fragments'.

Specimens: SD1-63 and SD1-68.

The two specimens are made of dense ferruginous marl rich in dolomitic silt. Macroscopically, they are identical, heavily sintered, with sharp margins of the fracture. Both on the

\footnotetext{
134 Eliyahu-Behar et al. 2008: 2901; Bettles 2003b.

135 Gilboa, Waiman-Barak, Jones 2015: 82, Fig. 5.

136 Bettles 2003b; Fabric Class 2A.
} 
surface and inside they are of a characteristic red colour and with numerous fine white spots of carbonates.

The matrix in PPL is dark-red, with numerous fine rhombohedral dolomite particles accompanied by irregular medium-sand grains of dolomitic rocks and oval grains of carbonates of a micrite structure up to $1.3 \mathrm{~mm}$ in size. Variously preserved foraminifer associations set the age of the material at Late Cretaceous.

What distinguishes the two samples is the presence of densely scattered glaukonite or pedo-features - presently fragments of ferruginous aluminium silicates of an intensive red colour. Some of them are amorphic, the rest are transparent with a laminar structure, showing undulose extinction.

\section{ANALOGIES}

Not known.

\section{PETROGRAPHIC GROUP VIII (Fig. 7:19)}

Dolomitic sand.

Specimens: SBc-19, SD1-70, SD2-78.

This is a macroscopically non-uniform group and its common feature is the presence of sand-sized rhomb-shaped dolomites. Due to the non-uniform character of the group each specimen was described separately.

\section{SPECIMEN SBC-19}

It is a fragment of a thin-walled vessel, light-red on the surface (5YR 7/6), dark grey inside. Under microscope, the calcareous matrix is devoid of quartz silt, reddish brown, optically active, with scattered rhombohedral crystals of dolomitic silt and single dark terra rossa balls. Sand-sized grains are oval grains of micritic limestone (15\% of the volume) and sparse angular polycrystalline dolomite crystals. The presence of foraminifers: Marssonella sp. (?lodoensis) Angulogerina sp., Tenuitella sp. is indicative for Paleogene.

\section{SPECIMEN SD1-70}

It is a thin-walled piece of pottery fired to a light red colour (2.5YR 6/8), inside the cross-section light brown. In transmitted light the groundmass is dark brown, residually optically active, rich in carbonate silt, which accounts for about $15 \%$ of the volume. Because of the high temperature of firing its carbonate content is hard to determine. The content of quartzsilt is much lower, at about $5 \%$ of the volume. The material is enriched with an admixture of terra rossa in the form of oval pellets. 
In spite of the relatively high temperature of firing, numerous foraminifers of the genus Globigerinelloides cf. bentonensis (Morrow), Heterohelix cf. reussi (Cushman) have been preserved, setting the age of the material at Late Cretaceous. The sand-sized admixture consists of angular crystals of dolomite, micritic on margins or replaced completely by micrite; their proportion is $c .10 \%$ of the volume.

\section{SPECIMEN SD2-78}

The sherd fired in reduced-oxygen conditions, steel-grey, made of marl with an admixture of dolomitic sand. The matrix of the sherd is dark brown in transmitted light, partly optically active, devoid of microfosils, with a few-millimetre elliptic clasts of dolomitic marl (with numerous fine rhombohedral dolomite particles embedded in its light brown argillaceous groundmass), smaller, irregular clasts of micritic chalk (light grey of very high porosity), and oval grains of non-transparent pure slag or sintered terra rossa. Quartz silt appears sporadically.

An aplastic admixture is represented by rhombohedral dolomites of the $0.2-0.5 \mathrm{~mm}$ fraction.

\section{AnAlogies}

Amarna tablets. ${ }^{137}$

\section{INTERPRETATION AND CONCLUSIONS}

A list of the results of petrographic analyses is presented in Tab. 1 together with archaeological typo-chrono identifications and their interpretation.

Jars of the Phoenician type, hole-mouthed with carinated shoulder (group 1a), dated to the Persian and the earlier Hellenistic periods, have a relatively uniform fabric belonging to the PG I.A1. They are light red-fired vessels composed of light marl enriched with ironbearing Globigerina chalk containing single clasts of Amphiroa sp. and tempered with quartz sand. This type of pottery is universally known from areas of Phoenician influence. According to earlier studies, ${ }^{138}$ it was produced in the coastal belt from Haifa northward towards Akko and beyond, especially in the region between Akko and Sidon.

Three (two?) jars of this shape (group 1a) have a different fabric assigned to PG IV; one jar was made of hamra soil (PG VI).

Jars of the hole-mouth Phoenician type with a thick rolled lip (group 1b), were produced in the Late Hellenistic to Early Roman periods. In the set examined, they have PG I.A1 fabric (five jars), which means that they also are products of the Phoenician coast.

\footnotetext{
137 Goren 1995; Goren, Finkelstein, Na'aman 2004: 262-269.

${ }^{138}$ Cf. Bettles 2003a: 73-74.
} 
Jars of the hole-mouth post-Phoenician type of an elongated, tubular shape (group 1c, Early Roman period to second-third centuries $\mathrm{AD}$ ), were made of a variety of materials assigned to:

- PG I.A1 - one jar (see above),

- PG I.A3 - one jar, local to Mt Carmel or the adjacent area,

- PG III - two jars, dolomitic Moza Formation fabric: Mt Carmel?, Samaria?

- PG II - one jar, silty soil.

Predominant among the non-Phoenician bag-shaped jars of group 2a (mostly Hellenistic, some of the Persian period?) are two variants of fabric called PG IV and PG V.

The fabric of PG IV (15 jars), fired in reduced-oxygen conditions to a creamy-white colour, is petrographically non-uniform. Generally, it is composed of highly calcareous marl of Late Cretaceous and Paleogene age, containing abundant foraminifers, some terra rossa balls, and even ferruginous argillaceous shale fragments. This group, internal differences notwithstanding, is distinct in chemical terms because of its highest content of phosphorus and high levels of $\mathrm{Ni}, \mathrm{Cr}$ and $\mathrm{U}$. Its petrographic subgroups, differing slightly in the composition of the paste used, can derive from many various local workshops operating at that time.

The fabric of PG V (11 jars) is also creamy beige or bright orange in colour, composed of highly calcareous marl, with fragments of marly shales, chalk clasts, and an admixture of ferruginous soil fired in reduced-oxygen conditions. This group also shows a high content of sand-sized quartz and glassy yellow hyaloclastites which, as in the case of PG I.A3, makes probable its link with the Mt Carmel region or adjacent areas.

Some of the bag-shaped vessels (group 2a) belong to PGs I.A2 and I.A3. Fired to a light red colour, they are composed of light calcareous marl rich in foraminifers and with some Amphiroa sp., but with no foraminiferous ferric oxides in favour of an admixture of terra rossa. And the fragments of pyroclastic hyaloclastite, 'yellow fragments', in the opinion of Israeli scholars, are proof of the material coming from the Mt Carmel/Um el-Fahm area, especially from the Carmel coast. Three jars of the 2a group are made of silty soil, one has a fabric rich in an admixture of dolomitic sand (PG VIII).

The Roman-period bag-shaped jars (group 2b, late first century $\mathrm{BC}$ - third century AD) were produced using a technology differing from that of the other amphorae, and mostly also of another raw material. The fabric predominating here, highly silty, makes up PG II (55 jars); it is composed of rendzina rich in quartz silt or silty terra rossa soil. Although this material is relatively uniform, because of its wide availability it cannot be associated with any specific ceramic workshop.

Amphorae especially distinct in petrographic terms are bag-shaped jars of group $2 \mathrm{~b}$, made of dolomitic marl and forming PG III (eight jars). This type of the material crops out along the Judean and Samarian hills (Upper Cretaceous Moza Formation), the equivalent of which is the Sakhnin Formation in the Mt Carmel region as well as in the central and western Galilee. ${ }^{139}$ It is also possible that the material comes

139 Cf. Kafri 1972: 16; Delage 2007: 45. 
from the weathered rock of the Karkara Member, which is the lower part of the Deir Hanna Formation. ${ }^{140}$

The examined samples of Hellenistic storage jars and dipper jugs (group 3a) have the fabric of PGs IV (3 specimens) and V (2 specimens); one has been made of silty soil (PG II). The Roman-period storage jars and jugs represent a Roman fabric, i.e. silty soil, or dolomitic marl.

From the archaeological perspective, a dramatic change in the fabrics of the amphorae at Sha'ar-Ha Amakim from the Early Roman period on doubtlessly deserves attention, as probably reflecting a new regional network of the sources of supply in jars. While from the late Iron Age (seventh/sixth century $\mathrm{BC})^{141}$ through the Late Hellenistic period many northern sites of the present-day Israel were supplied in jars both by the inland workshops and by those situated in the coastal zone, in the Roman period the products of the latter became very rare in the area of Sha'ar-Ha Amakim. This may be the result of a change in the ethnic/religious pattern of the settlement in the Lower Galilee, from gentile to Jewish, with the kashrut laws recommending the avoidance of vessels made in gentile workshops.

\section{Acknowledgments}

The investigations were sponsored by the National Science Centre, Poland, project no. NN 307 034940. Many thanks are due to Prof. Arthur Segal, Emeritus, the Zinman Institute of Archaeological Research, University of Haifa, for having supported one of the present author's (Jolanta Młynarczyk) study of the ceramics from Sha'ar-Ha Amakim. The authors are grateful to Prof. Barbara Olszewska for the micropalaeontoligcal analysis, and to Dr. Uzi Dahari, the Deputy Director of the IAA, for his granting the permit to export the jar samples from Israel. We are also grateful for Dr. Mariusz Burdajewicz for having prepared the drawings of the relevant pottery objects.

\section{References}

Adan-Bayewitz, D. 1993: Common Pottery in Roman Galilee. A Study of Local Trade, Ramat Gan

Adan-Bayewitz, D., Aviam, M. 1997: Iotapata, Josephus, and the siege of 67: preliminary report on the 1992-94 seasons, JRA 10, 131-165

Adan-Bayewitz, D., Wieder, M. 1992: Ceramics from Roman Galilee: A Comparison of Several Techniques for Fabric Characterization, JFA 19/2, 189-205

Alexandre, Y. 2006: Nahal Tut (Site VIII): A Fortified Storage Depot from the Late Fourth Century BCE, 'Atiqot 52, 131-189

\footnotetext{
140 Cf. Kafri 1972: 6; Sneh 2004.

141 Oshri, Gal 2010: 23.
} 
Alexandre, Y. 2013: Kafr Kanna (Jebel Khuwweikha) Iron II, Late Hellenistic and Roman Remains, HadArkh 125, 1-21

Arie, E., Buzaglo, E., Goren, Y. 2006: Petrographic Analysis of Iron Age I Pottery, [in:] Finkelstein, I., Ussishkin, D., Halpern, B. (Eds), Megiddo IV. The 1998-2002 Seasons II, Monograph Series 24, Tel Aviv, 558-567

Aviam, M. 2014: Kefar Hananya Ware made in Yodefat. Pottery production at Yodefat in the first century AD, [in:] Fisher-Genz, B., Gerber, Y., Hamel, H. (Eds), Roman Pottery in the Near East. Local Production and Regional Trade. Proceedings of the Round Table Held in Berlin 19-20 February 2010, Roman and Late Antique Mediterranean Pottery 3, Oxford, 139-146

Aviam, M. 2015: Yodefat - Jotapata. A Jewish Galilean Town at the End of the Second Temple Period: The Results of an Archaeological Project, [in:] Fiensy, D.A., Strange, J.R. (Eds), Galilee in the Late Second Temple and Mishnaic Periods II, Minneapolis, 109-126

Avissar, M. 1996: The Late Roman and Byzantine Pottery. The Medieval Pottery, [in:] Ben-Tor, A., Avissar, M., Portugali, Y., Yoqne'am I: The Late Periods, Qedem Reports 3, Jerusalem, 66-172

Avshalom-Gorni, D., Getzov, N. 2002: Phoenician and Jews. A ceramic case study, [in:] Berlin, A.M., Overman, J.A. (Eds), The First Jewish Revolt: Archaeology, History and Ideology, London-New York, 74-83

Avshalom-Gorni, D., Shapiro, A. 2015: A pottery workshop at Ahihud and its relationship to the jar industry in the northeastern Zevulun Valley and western Galilee during the Roman Period, 'Atiqot 83, 67-92

Bachmann, M., Hirsch, F. 2006: Lower Cretaceous carbonate platform of the eastern Levant (Galilee and Golan Heights): stratigraphy and second-order sea-level change, Cretaceous Research 27, 487-512

Bartov, Y. 1994: Geological photomap of Israel \& adjacent areas; Scale 1:750,000, The Geological Survey, Jerusalem

Barzilay, E. 2006: The Kurkar and Hamra Genesis of the Northern Hill of Tel Mikhal (Tel Michal), 'Atiqot 52, 127-130

Bentor, Y.K. 1966: The Clays of Israel. The International Clay Conference. Guide-Book to the Excursions, Israel Program for Scientific Translations, Jerusalem

Berlin, A. 1997: The Plain Wares, [in:] Berlin, A., Warner Slane, K., Tel Anafa II, i: The Hellenistic and Roman Pottery, JRA-Suppl. 10, Ann Arbor, MI, 1-211

Berlin, A. 2006: Gamla I. The Pottery of the Second Temple Period. The Shmarya Gutmann Excavations, 1976-1989, IAA Reports 29, Jerusalem

Berlin, A.M., Frankel, R. 2012: The Sanctuary at Mizpe Yammim: Phoenician Cult and Territory in the Upper Galilee during the Persian Period, BASOR 366, $25-78$

Bettles, E. 2003a: Carinated-Shoulder Amphorae from Sarepta, Lebanon: A Phoenician commodity and its intra-regional distribution, Archaeology \& History in Lebanon 17, $60-79$ 
Bettles, E.A. 2003b: Phoenician Amphora Production and Distribution in the Southern Coastal Levant: A multi-disciplinary investigation into carinated-shoulder amphorae of the Persian period (539-332 BC), BAR-IS 336, Oxford

Beydoun, Z.R. 1977: The Levantine Countries: The Geology of Syria and Lebanon (Maritime Regions), [in:] Nairn, A.E.M., Kanes, W.H., Stehli, F.G. (Eds), The Ocean Basins and Margins 4A. The Eastern Mediterranean, New York-London, 319-353

Briend, J., Humbert, J.-B. 1980: Tell Keisan (1971-1976), une cite phénicienne en Galilée, Fribourg-Göttingen-Paris

Buchbinder, B. 1975: Stratigraphic Significance of the Alga Amphiroa in Neogene-Quaternary Bioclastic Sediments from Israel, Israel Journal of Earth Sciences 24, 44-48

Buchbinder, B., Benjamini, Ch., Lipson-Benitah, S. 2000: Sequence development of Late Cenomanian-Turonian carbonate ramps, platforms and basins in Israel, Cretaceous Research 21/6, 813-843

Burdajewicz, M. 2009: Stone objects, [in:] Segal, A., Młynarczyk, J., Burdajewicz, M., Excavations of the Hellenistic Site in Kibbutz Sha'ar-Ha'Amakim (Gaba) 19841998, Final Report, Haifa, 203-213

Burdajewicz, M. 2015: Some Remarks on the Iron Age Pottery from Sha'ar-Ha'Amakim (Israel), EtudTrav XXVIII, 7-27

Calderon, R. 2000: Roman and Byzantine Pottery, [in:] Hirschfeld, Y. (Ed.), Ramat Hanadiv Excavations: Final Report of 1984-1998 Seasons, Jerusalem, 91-165

Cohen-Weinberger, A. 2013: Petrographic Analysis of Selected Vessels from the Southern Beach of Ashdod, 'Atiqot 74, 123-126

Cohen-Weinberger, A., Goren, Y. 2004: Levantine-Egyptian Interactions during the $12^{\text {th }}$ to the $15^{\text {th }}$ Dynasties Based on the Petrography of the Canaanite Pottery from Tell El-Dabca, $\ddot{A g L e v}$ XIV, 69-100

Cohen-Weinberger, A., Goren, Y. 2011: The Clay Sources of the Theater Pottery Workshop: A Petrographic Study, [in:] Bar-Nathan, R., Atrash, W., Bet She'an II, Beysan. The Theater Pottery Workshop. The Bet Shean Archaeological Project 1989-1999, IAA Report 48, Jerusalem, 215-228

Delage, C. 2007: Chert Availability in Israel and Palestine: A General Assessment Based on Data from the Galilee, [in:] Delage, C. (Ed.), Chert Availability and Prehistoric Exploitation in the Near East, BAR-IS 1615, Oxford, 29-54

Díez Fernández, F. 1983: Ceramica comun romana de la Galilea: Aproximaciones y diferencias con la ceramica del resto de Palestina y regiones circundantes Madrid

Elgavish, J. 1976: Pottery from the Hellenistic Stratum at Shiqmona, IEJ 26, 65-76

Elgavish, J. 1977: Archaeological Excavations at Shiqmona: The Pottery of the Roman Period, Haifa

Eliyahu-Behar, A., Shilstein, S., Raban-Gerstel, N., Goren, Y., Gilboa, A., Sharon, I., Weiner, S. 2008: An integrated approach to reconstructing primary activities from pit deposits: iron smithing and other activities at Tel Dor under Neo-Assyrian domination, JAS 35/11, 2895-2908 
Elyashiv, H., Bookman, R., Zviely, D., Aviam-Katav, S., Sandler, A., Sivan, D. 2015: The interplay between relative sea-level rise and sediment supply at the distal part of the Nile littoral cell, The Holocene 26/2, 248-264

Finkielsztejn, G. 2006: Some remarks on amphora productions and trade in the Southern Levant: territories and ethnicity, [in:] Malfitana, D., Poblome, J., Lund, J. (Eds), Old Pottery in a New Century: Innovating Perspectives on Roman Pottery Studies. Atti del Convegno Internazionale di Studi, Catania, 22-24 Aprile 2004, Monografie dell'Istituto per i Beni Archeologici e Monumentali - C.N.R. 1, Catania, 253-263

Finkielsztejn, G. 2009: Stamped Amphora Handles and Amphoras, [in:] Segal, A., Młynarczyk, J., Burdajewicz, M., Excavations of the Hellenistic Site in Kibbutz Sha'ar-Ha' Amakim (Gaba) 1984-1998: Final Report, Haifa, 120-147

Flexer, A. 1968: Stratigraphy and facies development of Mount Scopus Group (SenonianPaleocene) in Israel and adjacent countries, Israel Journal of Earth Sciences 17, 85-114

Gilboa, A., Cohen-Weinberger, A., Goren, Y. 2006: Philistine Bichrome Pottery: The View from the Northern Canaanite Coast. Notes on Provenience and Symbolic Properties, [in:] Maeir, A.M., de-Miroschedji, P. (Eds), "I will Speak the Riddle of Ancient Times": Archaeological and Historical Studies in Honor of Amihai Mazar on the Occasion of His Sixtieth Birthday 1, Winona Lake, Ind., 303-334

Gilboa, A., Waiman-Barak, P., Jones, R. 2015: On the Origin of Iron Age Phoenician Ceramics at Kommos, Crete: Regional and Diachronic Perspectives across the Bronze Age to Iron Age Transition, BASOR 374, 75-102

Goren, Y. 1995: Shrines and Ceramics in Chalcolithic Israel: The view through the petrographic microscope, Archaeometry 37/2, 287-305

Goren, Y., Finkelstein, I., Na'aman, N. 2004: Inscribed in Clay: Provenance Study of the Amarna Letters and other Ancient Near Eastern Texts, Tel Aviv University Sonia and Marco Nadler Institute of Archaeology, Monograph Series 23, Tel Aviv

Gorzalczany, A. 2006: Petrographic Analysis of the Tel Mikhal (Tel Michal) Pottery, 'Atiqot 52, 57-65

Gorzalczany, A. 2008: Petrographic Analysis of the Persian-Period Pottery from Horbat Malta, 'Atiqot 59, 81-86

Griffiths, D. 2003: Petrographic Analysis of Middle Bronze Age Burial Jars from Sidon, Archaeology \& History in Lebanon 17, 17-21

Gunneweg, J., Dothan, T., Perlman, I., Gitin, S. 1986: On the origin of pottery from Tel Miqne-Ekron, BASOR 264, 3-16

Guz-Silberstein, B. 1995: The Typology of the Hellenistic Coarse Ware and Selected Loci of the Hellenistic and Roman Periods, [in:] Stern, E. (Ed.), Excavations at Dor, Final Report, IB: Areas A and C: The Finds, Qedem Reports 2, Jerusalem, 289-433

Gvirtzman, G., Buchbinder, B. 1978: The late Tertiary of the coastal plain and continental shelf of Israel and its bearing on the history of the eastern Mediterranean, [in:] Ross, D.A., Neprochnov, Y.D., Hsü, K.J., Staffers, P., Supko, P., Trimonis, E.S., Percival, S.F. Jr., Erickson, A.J., Degens, E.T., Hunt, J.M., Manheim, F.T., Senalp, M., 
Traverse, A., Initial Reports of the Deep Sea Drilling Project 42/2, Washington, DC, 1195-1222

Horovitz, A. 1979: The Quaternary of Israel, New York-London-Toronto-Sydney-San Francisco

Issar, A. 1968: Geology of the Central Coastal Plain of Israel, Israel Journal of Earth Sciences 17, 16-29

Johnson, B.L. 1988: The Pottery, [in:] Davidson Weinberg, G. (Ed.), Excavations at Jalame, Site of a Glass Factory in Late Roman Palestine, Columbia, Mo., 137-226

Jones, H.A. 1965: Ferruginous oolites and pisolites, Journal of Sedimentary Petrology 35/4, $838-845$

Kafri, U. 1972: The lithostratigraphy and environments of deposition, Judea Group, Western and Central Galilee, Israel, Geological Survey of Israel Bulletin 54, 1-56

Kaminchik, J., Segev, A., Katzir, Y. 2014: The origin of intraplate alkaline mafic magmatism in continental shelves: lavas and xenoliths from the Upper Cretaceous volcanos of Mt Carmel, Geological Survey of Israel 19, Jerusalem

Karcz, I., Sneh, A. 2011: The Geological Map of Israel 1:50,000. Sheet 3-I: Hefa, Geological Survey of Israel, Jerusalem

Kingsley, S.A. 1999: The Sumaqa Pottery Assemblage: Classification and Quantification, [in:] Dar, S. (Ed.), Sumaqa. A Roman and Byzantine Jewish Village on Mount Carmel, Israel, BAR-IS 815, Oxford, 263-329

Landau, A.Y., Goren, Y. 2004: A Cypro-Minoan Potmark from Aphek, Tel Aviv 31/1, 22-31

Lapp, P.W. 1961: Palestinian Ceramic Chronology, 200 B.C. - A.D. 70, New Haven

Lehmann, G. 2001: Phoenicians in Western Galilee: First Results of an Archaeological Survey in the Hinterland of Akko, [in:] Mazar, A. (Ed.), Studies in the Archaeology of the Iron Age in Israel and Jordan, JSOT Supplement Series 331, Sheffield, 65-112

Leibner, U. 2009: Settlement and History in Hellenistic, Roman and Byzantine Galilee. An Archaeological Survey of the Eastern Galilee, Texts and Studies in Ancient Judaism 127, Tübingen

Levy, Y. 1983: The Geological Map of Israel 1:50,000 Sheet 3-II: Shefar'am. Explanatory Notes, Geological Survey of Israel, Jerusalem

Lipson-Benitah, S., Almogi-Labin, A., Sass, E. 1997: Cenomanian biostratigraphy and palaeoenvironments in the northwest Carmel region, northern Israel, Cretaceous Research 18/3, 469-491

Młynarczyk, J. 2000: Pottery from the Hellenistic Cistern at Sha'ar ha-Amakim (Lower

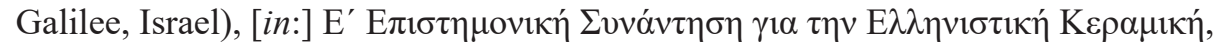

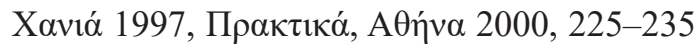

Młynarczyk, J. 2001: Local and Regional Wares at Tell Keisan in the Hellenistic Period, EtudTrav XIX, 237-262

Młynarczyk, J. 2009a: The Fort (the Central Structure): the Stratigraphy, [in:] Segal, A., Młynarczyk, J., Burdajewicz, M., Excavations of the Hellenistic Site in Kibbutz Sha'ar-Ha Amakim (Gaba) 1984-1998, Final Report, Haifa, 48-54 
Młynarczyk, J. 2009b: Hellenistic and Roman-period pottery from Sha'ar-Ha Amakim, [in:] Segal, A., Młynarczyk, J., Burdajewicz, M., Excavations of the Hellenistic Site in Kibbutz Sha'ar-Ha Amakim (Gaba) 1984-1998, Final Report, Haifa, 97-119 Nitschke, J.L., Martin, S.R., Shalev, Y. 2011: Between Carmel And The Sea. Tel Dor: The Late Periods, Near Eastern Archaeology 74/3, 132-154

Oshri, A., Gal, Z. 2010: A Seventh-century BCE Site near Tel 'En Zippori, 'Atiqot 63, 15-25 Porat, N. 1989: Composition of pottery - application to the study of the interrelations between Canaan and Egypt during the 3rd millenium B.C., unpublished $\mathrm{PhD}$ thesis, Hebrew University of Jerusalem, Jerusalem

Ravikovitch, S. 1969: Soil Map 1:250,000 Hebrew University of Jerusalem, Faculty of Agriculture Rehovot

Regev, D. 2009-2010: 'Akko-Ptolemais, a Phoenician City: the Hellenistic Pottery, MeditArch 22/23, 115-191

Reynolds, P. 1997-1998: Pottery production and economic exchange in second century Berytus: Some preliminary observations of ceramic trends from quantified ceramic deposits from the Souks excavations in Beirut, Berytus XLIII, 35-110

Reynolds, P. 2005: Levantine amphorae from Cilicia to Gaza: a Typology and Analysis of Regional Production Trends from the 1st to 7th Centuries, [in:] Gurt i Esparraguera, J.M., Buxeda i Garrigós, J., Cau Ontiveros, M.A. (Eds), LRCW I. Late Roman Coarse Wares, Cooking Wares and Amphorae in the Mediterranean: Archaeology and Archaeometry (Barcelona, 14-16th March 2002), BAR-IS 1340, Oxford, 563-611

Safrai, Z. 1994: The Economy of Roman Palestine, London-New York

Sass, E., Bein, A. 1982: The Cretaceous carbonate platform in Israel, Cretaceous Research 3/1-2, 135-144

Segev, A. 2005: Phanerozoic Magmatic Activity Associated with Vertical Motions in Israel and the Adjacent Countries, [in:] Hall, J.K., Krasheninnikov, V.A., Hirsh, F., Benjamini, Ch., Flexer, A. (Eds), Geological Framework of the Levant II: The Levantine Basin and Israel, Jerusalem, 553-577

Segev, A., Sass, E. 2009: The Geological Map of Israel 1:50,000 Sheet 3-III: Atlit, Geological Survey of Israel, Jerusalem

Segev, A., Sass, E., Ron, H., Lang, B., Kolodny, Y., McWilliams, M. 2002: Stratigraphic, geochronologic, and paleomagnetic constrains on Late Cretaceous volcanism in northern Israel, Israel Journal of Earth Sciences 51/3-4, 297-309

Shapira, Y. 1966: An Ancient Cave at Bat-Yam, IEJ 16, 8-10, Pls 2-4

Shapiro, A. 2014: Petrographic Study of Selected Mamluk-Period Pottery from Khirbat Din'ila, 'Atiqot 78, 105-112

Singer-Avitz, L. 1989: Local pottery of the Persian Period (Strata XI-VI), [in:] Herzog, Z., Rapp, G. Jr., Negbi, O. (Eds), Excavations at Tel Michal, Israel, Minneapolis-Tel Aviv, 115-144

Sivan, D., Gvirtzman, G., Sass, E. 1999: Quaternary Stratigraphy and Paleogeography of the Galilee Coastal Plain, Israel, Quaternary Research 51/3, 280-294 
Smithline, H. 2009: Pottery and a Small Find from the Persian and Hellenistic Periods, [in:] Getzov, N. et al., Horbat 'Uza. The 1991 Excavations I: The Early Periods, IAA Reports 41, Jerusalem, 136-149

Smithline, H. 2013: A Unique Hellenistic Pottery Assemblage from 'Akko, 'Atiqot 76, $71-103$

Sneh, A. 2004: The Geological Map of Israel 1:50,000 Sheet 1-IV: Nahariyya, Geological Survey of Israel, Jerusalem

Sneh, A. 2008: The Geological Map of Israel 1:50,000 Sheet 3-II: Shefar'am, Geological Survey of Israel, Jerusalem

Sneh, A., Bartov, Y., Rosensaft, M. 1998: Geological map of Israel, Sheet 1, 1:200 000, Geological Survey of Israel, Jerusalem

Stager, L.E. 2011: Pottery Classification and Petrographic Analysis, [in:] Stager, L.E, Master, D.M., Schloen, J.D., The Seventh Century B.C., The Leon Levy Expedition to Ashkelon, Ashkelon 3, Winona Lake, Ind., 53-70

Tsuk, T., Rosenberger, A., Peilstocker, M. 1996: The Ancient Reservoir of Zippori, Excavations 1993-1994, Tel Aviv

Walley, Ch.D. 1997: Litostratigraphy of Lebanon. A Review, Lebanese Science Bulletin 10/1, 81-108

Walley, Ch.D. 1998: Some outstanding issues in the geology of Lebanon and their importance in the tectonic evolution of the Levantine region, Tectonophysics 298, 37-62

Wieder, M., Adan-Bayewitz, D. 1999: Pottery manufacture in early Roman Galilee: a micromorphological study, Catena 35/2-4, 327-341

Zemer, A. 1978: Storage Jars in Ancient Sea Trade, Haifa

Zviely, D., Kit, E., Klein, M. 2007: Longshore sand transport estimates along the Mediterranean coast of Israel in the Holocene, Marine Geology 238, 61-73

Zviely, D., Sivan, D., Ecker, A., Bakler, N., Rohrlich, V., Galili, E., Boaretto, E., Klein, M., Kit, E. 2006: Holocene evolution of the Haifa Bay area, Israel, and its influence on ancient tell settlements, The Holocene 16/6, 849-861 


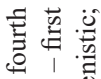
ปิ อิ 证 色 或 言空㱏 递害芦 品 产.

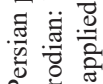
\% 공 $\exists \vec{a}$ 足 表 눙

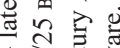
1 市 品它焉 응 齐二 。․ .

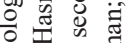
然.

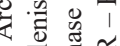
誩 产 중. 可 폰 荘

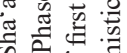

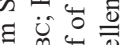

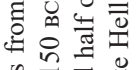

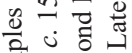
인 政 사에

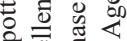
인오를 竞安 记 政产 政

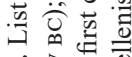

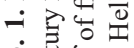

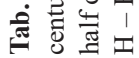

\begin{tabular}{|c|c|c|c|c|c|c|c|c|c|c|}
\hline 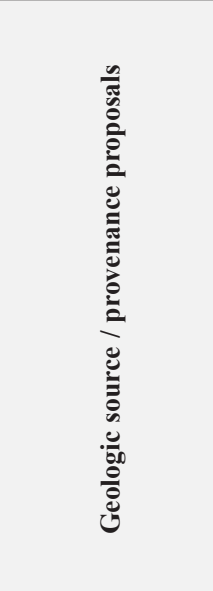 & 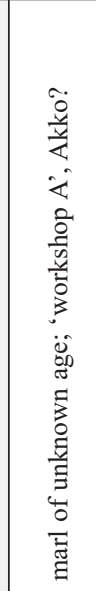 & 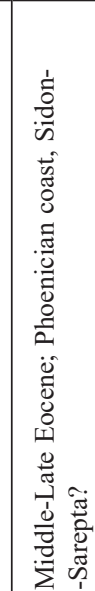 & 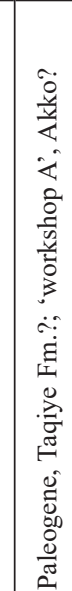 & 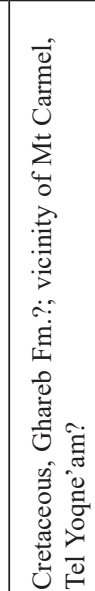 & 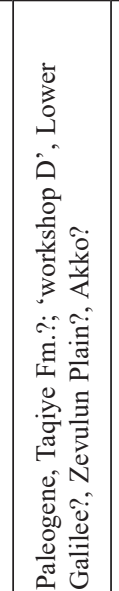 & 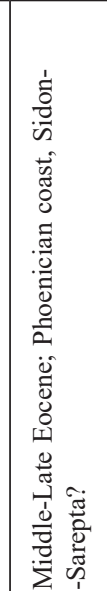 & 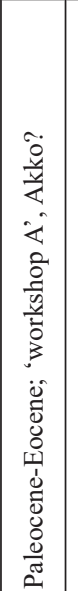 & 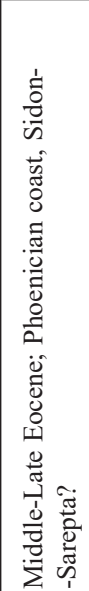 & 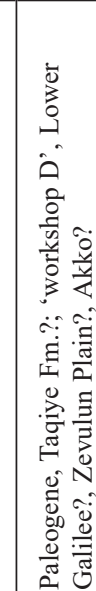 & 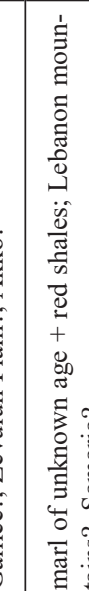 \\
\hline 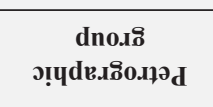 & 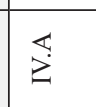 & $\Xi$ & 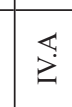 & $>$ & $\stackrel{\nexists}{\geqq}$ & $\Xi$ & $\overleftrightarrow{\sharp}$ & $\Xi$ & $\stackrel{\nexists}{\geqq}$ & $\stackrel{u}{Z}$ \\
\hline dnotis passen & I & $\cong$ & $\frac{\mathscr{n}}{n}$ & .. & $\cong$ & $\cong$ & | & 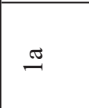 & $\cong$ & ๙ \\
\hline ṣ̣̌e & 吾 & $\cong$ & 踾 & 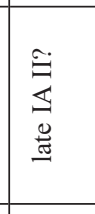 & $\therefore$ & 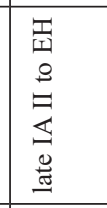 & 立 & \begin{tabular}{|l}
$\frac{7}{4}$ \\
$\vdots$ \\
0 \\
0
\end{tabular} & 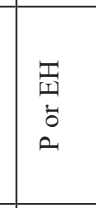 & $a$ \\
\hline 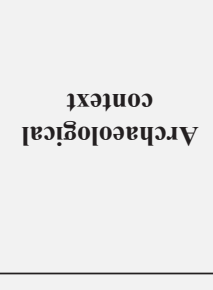 & 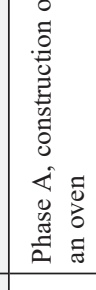 & \begin{tabular}{|l} 
总 \\
童
\end{tabular} & 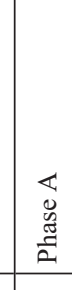 & 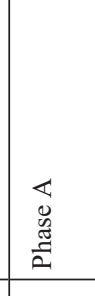 & 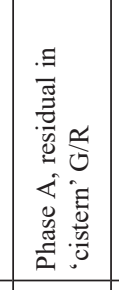 & 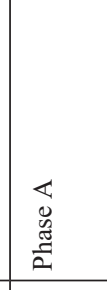 & 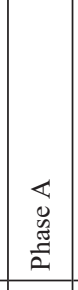 & 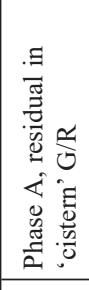 & 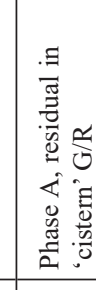 & 告 \\
\hline 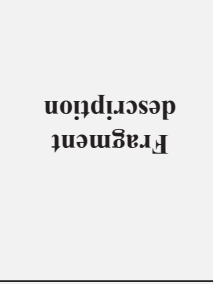 & 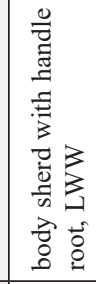 & 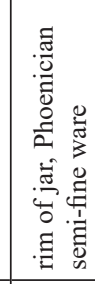 & 焉 & 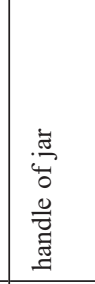 & 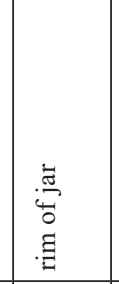 & 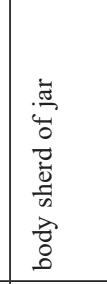 & 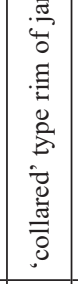 & 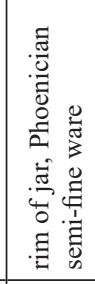 & 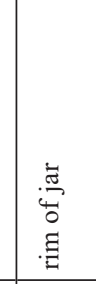 & \\
\hline 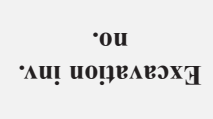 & 志 & 售 & : & 悉 & \begin{tabular}{|l} 
\\
蓄 \\
\end{tabular} & II & 美 & $\frac{9}{3}$ & 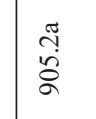 & \\
\hline loquis s ofdures & $\frac{\bar{z}}{\dot{x}}$ & $\frac{\pi}{2}$ & $\frac{7}{n}$ & $\frac{7}{n}$ & $\frac{6}{3}$ & 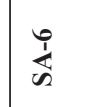 & $\tilde{n}$ & $\frac{t}{n}$ & $\frac{9}{\dot{3}}$ & \\
\hline
\end{tabular}




\begin{tabular}{|c|c|c|c|c|c|c|c|c|c|c|c|c|c|c|}
\hline 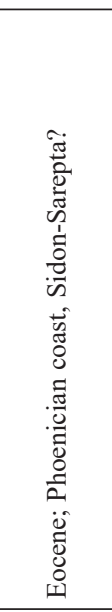 & 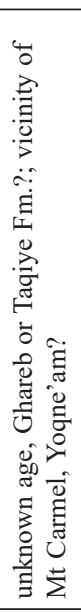 & 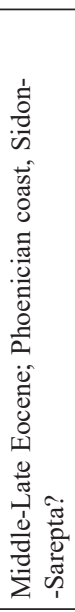 & 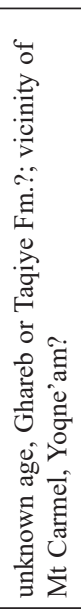 & 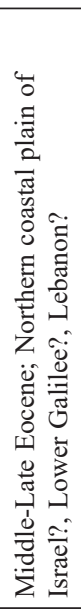 & 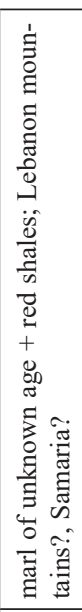 & 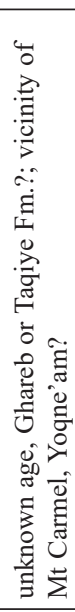 & 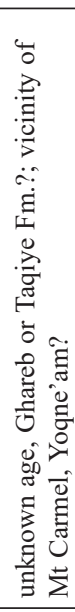 & 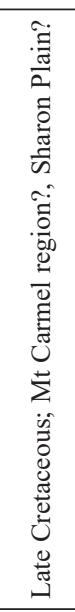 & 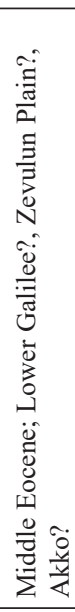 & 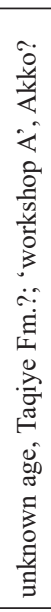 & 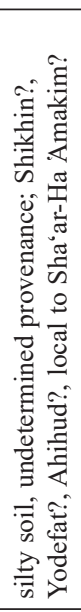 & 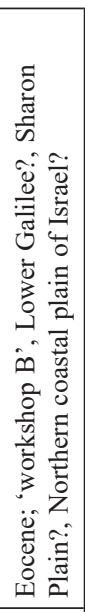 & 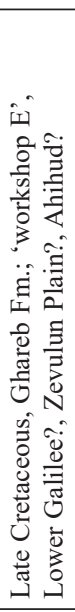 & 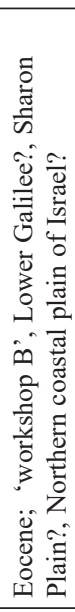 \\
\hline$\underset{\leftrightarrows}{\longleftarrow}$ & $>$ & 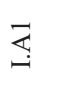 & $>$ & $\underset{3}{2}$ & $\stackrel{u}{Z}$ & $>$ & $>$ & 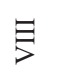 & $\stackrel{9}{\gtrless}$ & 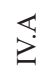 & $\overleftrightarrow{\Xi}$ & $\stackrel{m}{\geq}$ & 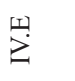 & 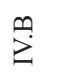 \\
\hline 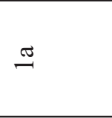 & तూ & $\Xi$ & $\widetilde{\sim}$ & $\widetilde{\sim}$ & $\widetilde{\sim}$ & $\widetilde{\sim}$ & $\begin{array}{l}\tilde{N} \\
\tilde{0} \\
\tilde{N} \\
\tilde{N}\end{array}$ & $\begin{array}{l}\tilde{J} \\
\tilde{5} \\
\tilde{N} \\
\tilde{J}\end{array}$ & तూ & $\widetilde{\sim}$ & ते & $\tilde{n}$ & $\widetilde{\sim}$ & లే \\
\hline $\begin{array}{l}\mathbb{I} \\
\text { I } \\
\dot{0} \\
0\end{array}$ & 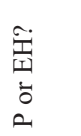 & $\begin{array}{l}\mathbb{T} \\
\vec{y} \\
\dot{0} \\
0\end{array}$ & \pm & \pm & 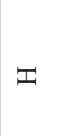 & $\Psi$ & 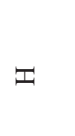 & \pm & 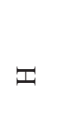 & \pm & $\frac{\widetilde{r}}{\square}$ & $\Psi$ & 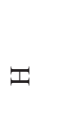 & 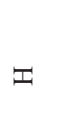 \\
\hline 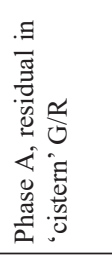 & 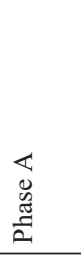 & 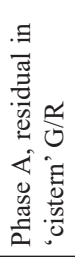 & $\begin{array}{l}m \\
0 \\
0 \\
\Xi \\
\tilde{D}\end{array}$ & $\begin{array}{l}m \\
0 \\
\tilde{E} \\
\tilde{E}\end{array}$ & $\begin{array}{l}m \\
\tilde{D} \\
\tilde{E} \\
\tilde{E}\end{array}$ & $\begin{array}{l}m \\
0 \\
\tilde{J} \\
\frac{\pi}{\omega}\end{array}$ & $\begin{array}{l}m \\
0 \\
\tilde{J} \\
\frac{\pi}{D}\end{array}$ & 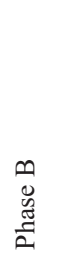 & $\begin{array}{l}m \\
0 \\
\tilde{J} \\
\frac{\pi}{2}\end{array}$ & $\begin{array}{l}m \\
\tilde{0} \\
\tilde{z} \\
\frac{\pi}{2}\end{array}$ & 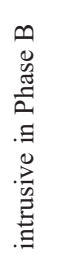 & $\begin{array}{l}m \\
\tilde{D} \\
\tilde{z} \\
\frac{\pi}{2}\end{array}$ & $\begin{array}{l}0 \\
0 \\
\tilde{z} \\
\frac{\pi}{2}\end{array}$ & $\begin{array}{l}m \\
0 \\
0 \\
\tilde{E} \\
\frac{\pi}{2}\end{array}$ \\
\hline 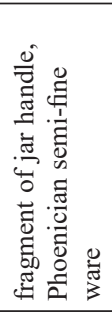 & 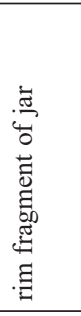 & 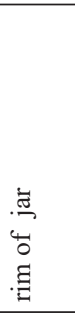 & 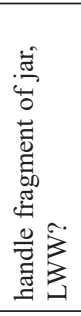 & 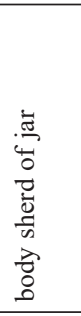 & 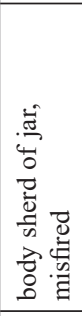 & 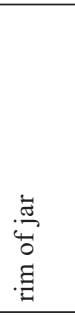 & 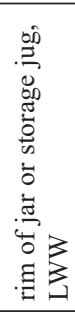 & 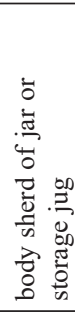 & 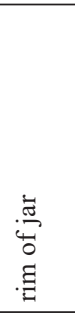 & 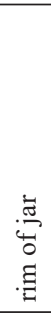 & 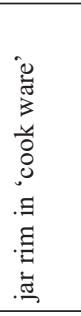 & 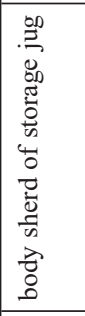 & 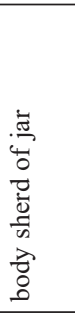 & 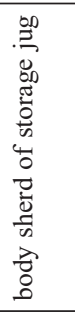 \\
\hline \&̊ & $\frac{\pi}{\pi}$ & 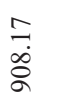 & $\infty_{\infty}^{\infty}$ & $\underset{\substack{\infty \\
\infty \\
\infty}}{\stackrel{\infty}{\infty}}$ & $\underset{\infty}{\stackrel{\pi}{\leftrightarrow}}$ & 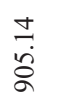 & $\begin{array}{l}\text { Nै } \\
\infty \\
\infty \\
\infty\end{array}$ & $\frac{\hat{i}}{a}$ & \begin{tabular}{l}
\multirow{\leftrightarrow}{\infty}{} \\
$\infty$ \\
$\infty$
\end{tabular} & $\frac{1}{\stackrel{\circ}{\circ}}$ & $\begin{array}{l}\infty \\
\infty \\
\infty \\
\infty\end{array}$ & $\mid \begin{array}{l}n \\
\infty \\
\infty \\
\infty\end{array}$ & $\begin{array}{l}\stackrel{\pi}{0} \\
\sigma\end{array}$ & $\underset{\infty}{\stackrel{亠}{\infty}}$ \\
\hline$\frac{7}{i_{n}^{\prime}}$ & $\frac{N}{\frac{1}{4}}$ & $\frac{m}{\infty}$ & $\begin{array}{l} \pm \\
\text { d } \\
\text { טै }\end{array}$ & $\begin{array}{l}\frac{10}{8} \\
\text { 号 }\end{array}$ & $\begin{array}{l}0 \\
\text { 'ं } \\
\text { ثै }\end{array}$ & $\begin{array}{l}\bar{j} \\
\text { 峁 }\end{array}$ & $\begin{array}{l}\frac{\infty}{J} \\
\text { tै }\end{array}$ & $\begin{array}{l}\hat{j} \\
\text { जै }\end{array}$ & $\begin{array}{l}\text { त̃ } \\
\text { బै }\end{array}$ & $\begin{array}{l}\overrightarrow{\mathcal{J}} \\
\text { जै }\end{array}$ & 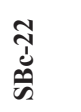 & 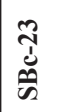 & $\begin{array}{l}\text { İ } \\
\text { है }\end{array}$ & 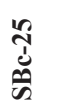 \\
\hline
\end{tabular}




\begin{tabular}{|c|c|c|c|c|c|c|c|c|c|c|c|c|c|}
\hline 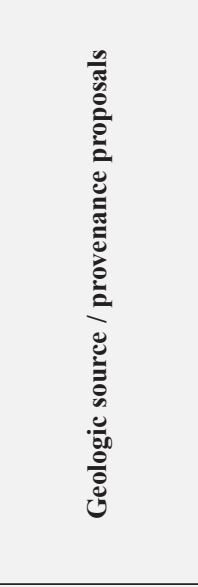 & 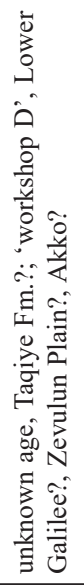 & 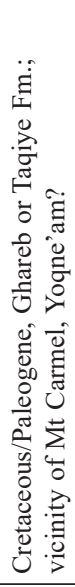 & 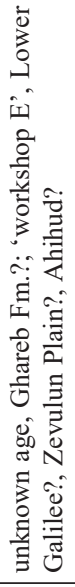 & 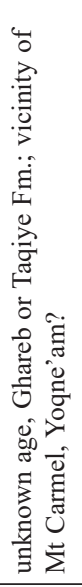 & 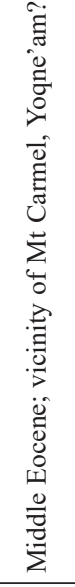 & 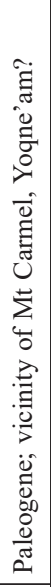 & 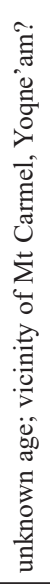 & 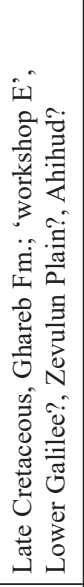 & 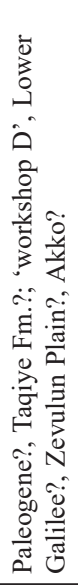 & 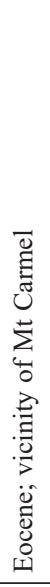 & 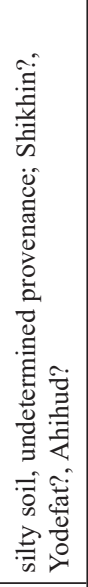 & 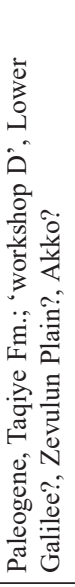 & 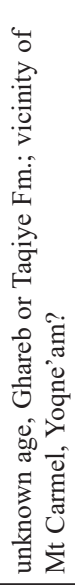 \\
\hline 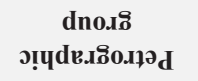 & $\stackrel{9}{2}$ & $>$ & $\stackrel{\text { 눌 }}{\geq}$ & $>$ & $>$ & $>$ & $>$ & $\stackrel{\text { II }}{2}$ & $\stackrel{\rho}{\gtrless}$ & $\stackrel{m}{\leftrightarrows}$ & $\stackrel{\oplus}{9}$ & $\stackrel{9}{\gtrless}$ & $>$ \\
\hline dno.ı̊ [əssə⿹ & 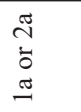 & $\widetilde{\sim}$ & तึ & $\overparen{N}$ & $\pi$ & तూ & तూ & $\overparen{N}$ & $\widetilde{N}$ & $\overparen{N}$ & $\vec{\sim}$ & ก็ & $\tilde{\widetilde{\sim}}$ \\
\hline su!̣ed & 茌 & \pm & 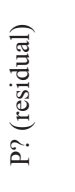 & \pm & I & \pm & I & \pm & I & \pm & 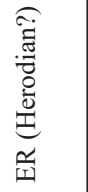 & I & \pm \\
\hline 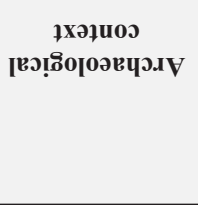 & 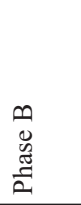 & $\begin{array}{l}\infty \\
0 \\
0 \\
\tilde{\Xi} \\
\frac{\pi}{\alpha}\end{array}$ & $\begin{array}{l}\infty \\
0 \\
0 \\
\frac{\pi}{\sigma} \\
\end{array}$ & $\begin{array}{l}\infty \\
0 \\
0 \\
\frac{\pi}{\sigma} \\
\frac{\pi}{\sigma}\end{array}$ & 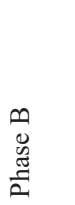 & 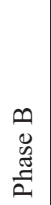 & $\begin{array}{l}m \\
0 \\
0 \\
\tilde{\Xi} \\
\frac{\pi}{2}\end{array}$ & 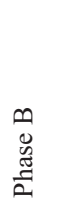 & $\begin{array}{l}m \\
0 \\
\tilde{z} \\
\frac{\pi}{2}\end{array}$ & 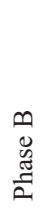 & 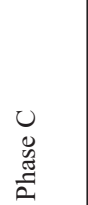 & 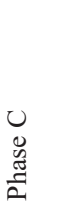 & $\begin{array}{l}U \\
0 \\
\tilde{Z} \\
\frac{\pi}{2}\end{array}$ \\
\hline 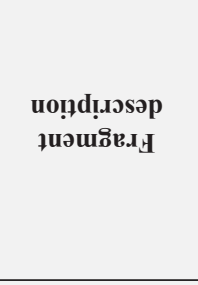 & 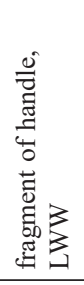 & 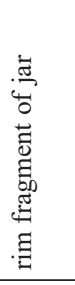 & 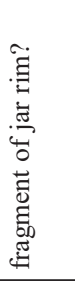 & 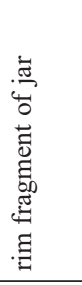 & 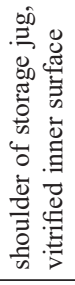 & 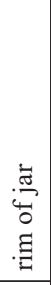 & 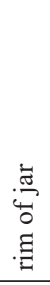 & 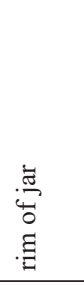 & 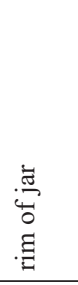 & 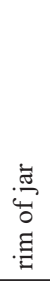 & 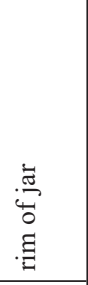 & 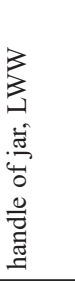 & 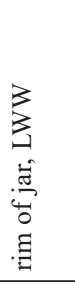 \\
\hline 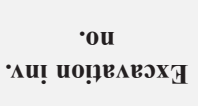 & \& & $\begin{array}{l}\stackrel{\partial}{\Delta} \\
\stackrel{\alpha}{\infty}\end{array}$ & $\begin{array}{l}\frac{m}{\circ} \\
\frac{\circ}{2}\end{array}$ & $\begin{array}{l}0 \\
\stackrel{1}{\circ} \\
\square\end{array}$ & $\bar{\infty}$ & 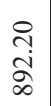 & 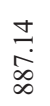 & $\underset{\tilde{2}}{\tilde{\infty}}$ & 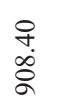 & $\begin{array}{l} \pm \\
\stackrel{\Delta}{\infty}\end{array}$ & $\stackrel{0}{0}$ & : & $\begin{array}{l}\dot{0} \\
\dot{0}\end{array}$ \\
\hline [oquis ә]durs & 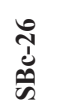 & 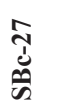 & 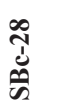 & 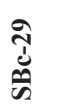 & 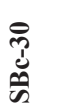 & $\begin{array}{l}\overline{\tilde{d}} \\
\text { कै }\end{array}$ & $\begin{array}{l}\text { है } \\
\text { ڤึ }\end{array}$ & $\begin{array}{l}\tilde{d} \\
\text { कै }\end{array}$ & $\begin{array}{l}\text { 岁 } \\
\text { 㟔 }\end{array}$ & $\begin{array}{l}\tilde{3} \\
\text { है } \\
\text { कै }\end{array}$ & ర్ల & 仓̂́ & $\bigcup_{\infty}^{\infty}$ \\
\hline
\end{tabular}




\begin{tabular}{|c|c|c|c|c|c|c|c|c|c|c|c|c|c|c|c|}
\hline 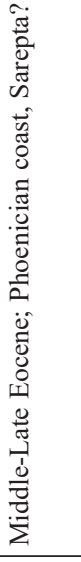 & 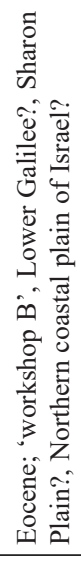 & 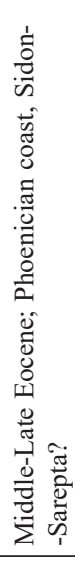 & 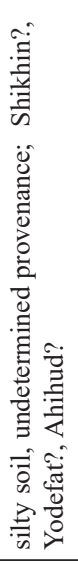 & 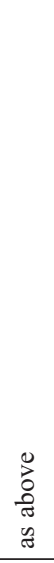 & 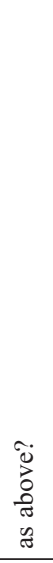 & $\begin{array}{l}0 \\
0 \\
0 \\
0 \\
0 \\
0 \\
0\end{array}$ & 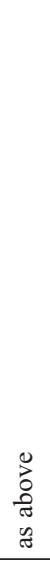 & $\begin{array}{l}0 \\
0 \\
0 \\
0 \\
\tilde{\sigma} \\
\end{array}$ & 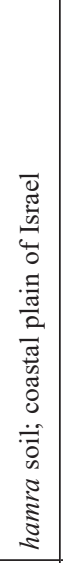 & 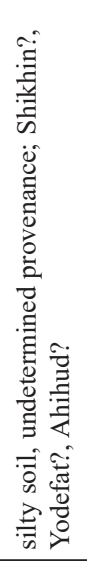 & 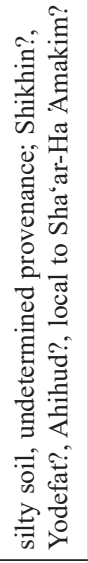 & 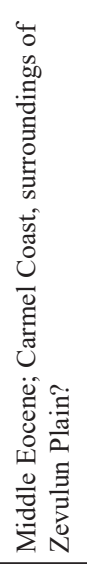 & 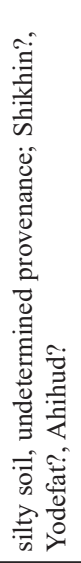 & 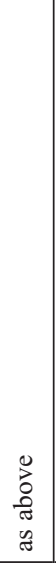 & 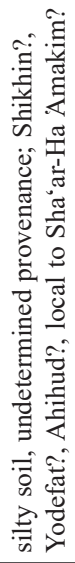 \\
\hline 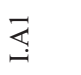 & $\stackrel{m}{\gtrless}$ & $\rightleftarrows$ & $\stackrel{\rho}{\text { 是 }}$ & $\stackrel{\ominus}{\text { 星 }}$ & $\stackrel{\oplus}{\boxminus}$ & $\stackrel{\rho}{\text { 是 }}$ & $\stackrel{\circlearrowright}{\ominus}$ & $\stackrel{?}{=}$ & 5 & 肙 & 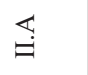 & $\underset{\nearrow}{\longleftarrow}$ & 昌 & $\stackrel{\rho}{\mathrm{G}}$ & 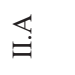 \\
\hline$\stackrel{\pi}{=}$ & 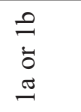 & $\cong$ & $\vec{\sim}$ & ते & $\vec{\sim}$ & ते & $\vec{\sim}$ & $\vec{\sim}$ & $\vec{\sim}$ & ले & $\vec{\sim}$ & $\vec{\sim}$ & ले & $\vec{\sim}$ & $\vec{\sim}$ \\
\hline 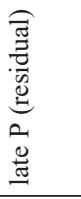 & \pm & 寻 & $\simeq$ & $\simeq$ & $\simeq$ & $\simeq$ & $\simeq$ & $\simeq$ & $\simeq$ & $\simeq$ & $\simeq$ & $\simeq$ & $\simeq$ & $\simeq$ & $\simeq$ \\
\hline 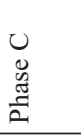 & 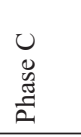 & 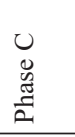 & 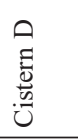 & 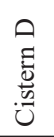 & $\begin{array}{c}0 \\
\tilde{D} \\
.02 \\
0\end{array}$ & 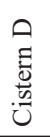 & 章 & 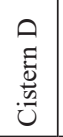 & $\begin{array}{c}0 \\
\tilde{D} \\
.00 \\
ن\end{array}$ & 号 & 竭 & 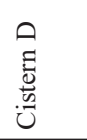 & 畕 & 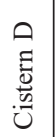 & 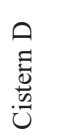 \\
\hline 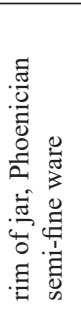 & 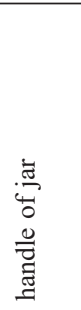 & 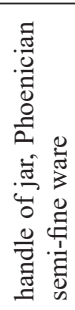 & 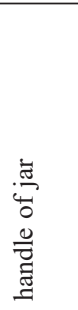 & 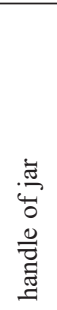 & 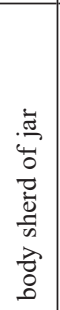 & 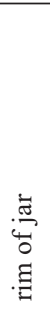 & 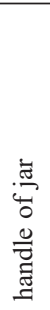 & 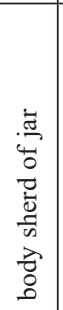 & 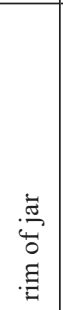 & 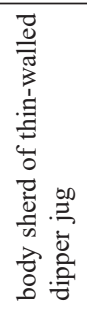 & 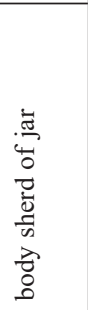 & 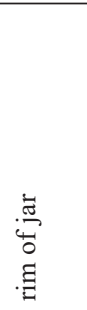 & 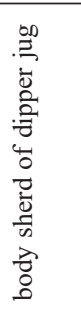 & 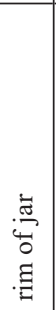 & 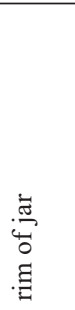 \\
\hline $\begin{array}{l}\overparen{D} \\
\stackrel{0}{0}\end{array}$ & $\begin{array}{l}\overparen{0} \\
\stackrel{0}{\infty}\end{array}$ & 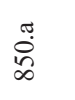 & $\underset{\sim}{\stackrel{0}{n}}$ & $\underset{\sim}{\stackrel{0}{n}}$ & 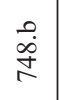 & $\begin{array}{l}0 \\
\stackrel{\infty}{0} \\
\stackrel{N}{N}\end{array}$ & $\underset{\stackrel{\pi}{\sim}}{\stackrel{r}{r}}$ & $\begin{array}{c}\pi \\
\stackrel{0}{+} \\
\stackrel{0}{i}\end{array}$ & 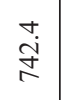 & $\stackrel{\text { 年 }}{\sim}$ & $\begin{array}{c}\dot{0} \\
\stackrel{+}{+}\end{array}$ & $\begin{array}{l}\text { సे } \\
\stackrel{+}{ \pm}\end{array}$ & 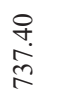 & $\begin{array}{l}\stackrel{0}{2} \\
\stackrel{7}{7} \\
\stackrel{+}{7}\end{array}$ & 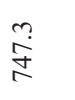 \\
\hline ల్ & $\underset{n}{\stackrel{J}{J}}$ & $\underset{n}{7}$ & $\begin{array}{l}\text { †े } \\
\text { ڤ̆ }\end{array}$ & 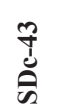 & 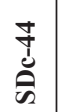 & $\begin{array}{l}\text { fo } \\
\text { Oั } \\
\text { के }\end{array}$ & $\begin{array}{l}\text { +ீ } \\
\text { ஸ̆ } \\
\text { के }\end{array}$ & $\begin{array}{c}\tilde{f} \\
\stackrel{0}{O} \\
\text { On }\end{array}$ & $\begin{array}{l}\stackrel{\infty}{+} \\
\stackrel{0}{0} \\
\text { On }\end{array}$ & $\begin{array}{l}\stackrel{+}{d} \\
\text { कू }\end{array}$ & 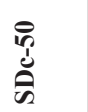 & $\begin{array}{l}\overline{\check{d}} \\
\tilde{\tilde{n}}\end{array}$ & $\begin{array}{l}\tilde{d} \\
\tilde{ٌ} \\
\tilde{\sigma}\end{array}$ & 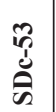 & $\begin{array}{l}\text { 号 } \\
\text { ڤั }\end{array}$ \\
\hline
\end{tabular}




\begin{tabular}{|c|c|c|c|c|c|c|c|c|c|c|c|c|c|c|}
\hline 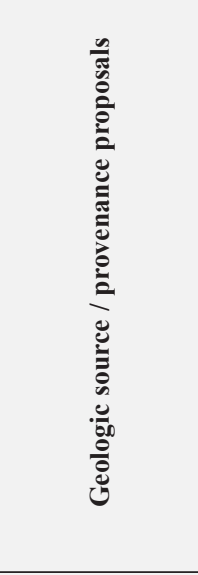 & $\begin{array}{l}0 \\
0 \\
\tilde{\sigma} \\
\tilde{\sigma} \\
\tilde{\sigma}\end{array}$ & 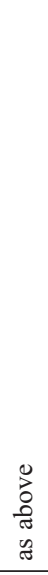 & 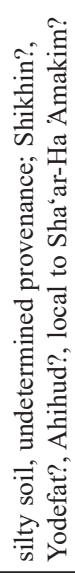 & 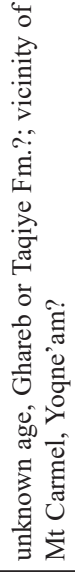 & 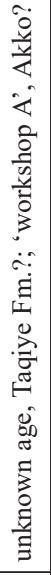 & 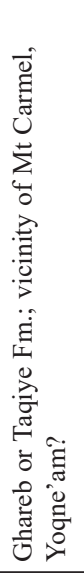 & 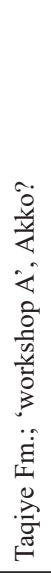 & 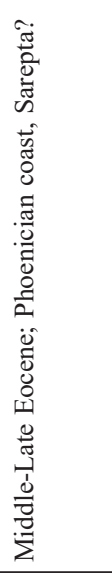 & 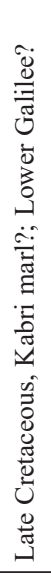 & 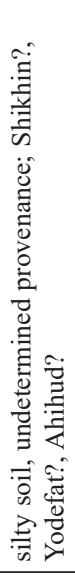 & 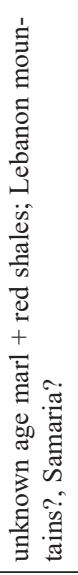 & 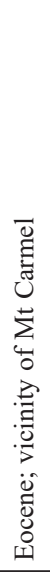 & 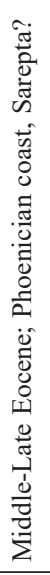 & 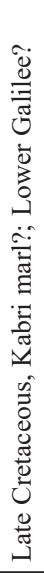 \\
\hline 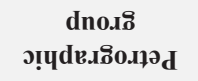 & คํ보 & 昌 & 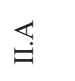 & $>$ & $\overleftrightarrow{\gtrless}$ & $>$ & 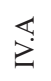 & 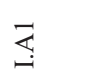 & F & $\stackrel{\oplus}{\oplus}$ & $\stackrel{\circlearrowright}{\gtrless}$ & $\stackrel{m}{\longleftarrow}$ & $\rightleftarrows$ & $\$$ \\
\hline 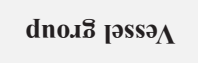 & ले & $\vec{\sim}$ & $\vec{\sim}$ & तึ & $\widetilde{N}$ & సొ & $\widetilde{\sim}$ & $=$ & $\vec{\sim}$ & $\widetilde{\sim}$ & $\widetilde{\sim}$ & $\widetilde{\sim}$ & $\ddot{\Leftrightarrow}$ & ते \\
\hline 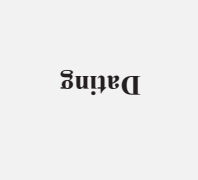 & $\simeq$ & $\simeq$ & $\simeq$ & 寻 & 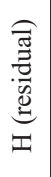 & 寻 & 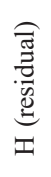 & 岑 & $\underset{r}{\stackrel{\alpha}{r}}$ & 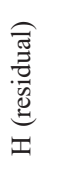 & 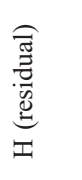 & 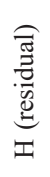 & 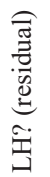 & $\stackrel{\text { r. }}{\text { II }}$ \\
\hline 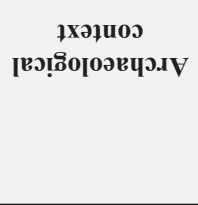 & 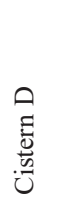 & 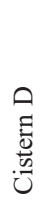 & 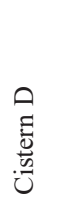 & $\begin{array}{l}\vec{D} \\
\mathbb{u} \\
\vec{z} \\
\overrightarrow{0}\end{array}$ & $\begin{array}{l}\overrightarrow{\vec{D}} \\
\tilde{0} \\
\tilde{g} \\
\vec{a}\end{array}$ & $\begin{array}{l}\vec{D} \\
\tilde{D} \\
\tilde{\Xi} \\
\vec{a}\end{array}$ & $\begin{array}{l}\vec{D} \\
0 \\
\tilde{D} \\
\underline{\tilde{D}}\end{array}$ & $\begin{array}{l}\vec{D} \\
0 \\
\tilde{D} \\
\underline{\tilde{D}}\end{array}$ & $\begin{array}{l}\vec{D} \\
\tilde{D} \\
\overline{\tilde{g}} \\
\underline{0}\end{array}$ & 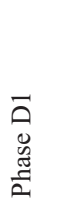 & 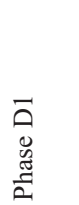 & $\begin{array}{l}\vec{D} \\
0 \\
o \\
\tilde{\Xi}\end{array}$ & $\begin{array}{l}\vec{D} \\
0 \\
\mathscr{0} \\
\text { a }\end{array}$ & $\begin{array}{l}\vec{D} \\
0 \\
\tilde{z} \\
\bar{\Xi}\end{array}$ \\
\hline 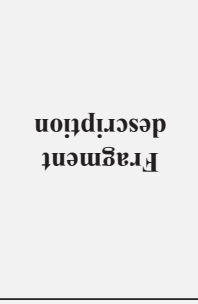 & 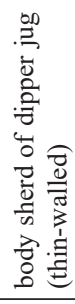 & 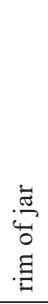 & 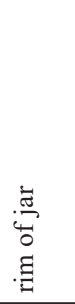 & 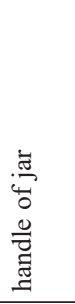 & 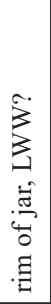 & 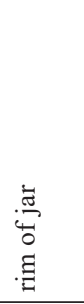 & 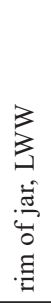 & 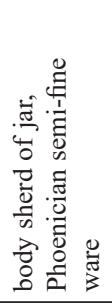 & 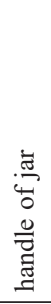 & 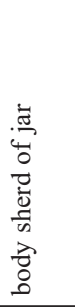 & 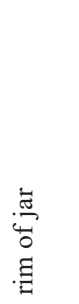 & 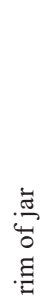 & 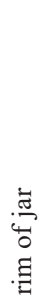 & 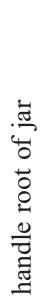 \\
\hline 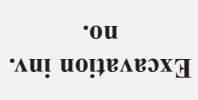 & $\begin{array}{l}\vec{n} \\
\ddot{n}\end{array}$ & 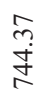 & 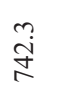 & तु & $\begin{array}{l}\text { त्रे } \\
\text { ते }\end{array}$ & 莡 & $\begin{array}{l}\text { तु } \\
\text { ָे }\end{array}$ & चूं & $\hat{n}$ & 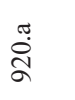 & $\begin{array}{l}\circ \\
\text { ๙े }\end{array}$ & $\begin{array}{l}\text { نें } \\
\text { i }\end{array}$ & $\begin{array}{l}\stackrel{\sigma}{+} \\
\stackrel{\sim}{d}\end{array}$ & సે \\
\hline ןoquís ə|durs & $\begin{array}{l}\mathscr{n} \\
\tilde{ٌ} \\
\text { की }\end{array}$ & 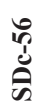 & $\begin{array}{l}\hat{\mathscr{J}} \\
\tilde{\tilde{n}}\end{array}$ & 亦 & $\frac{i}{i}$ & $\begin{array}{l}\text { : } \\
\text { in } \\
\text { क }\end{array}$ & $\begin{array}{l}\overline{0} \\
\frac{1}{\sigma} \\
\text { कs }\end{array}$ & 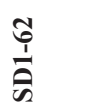 & $\begin{array}{l}3 \\
\frac{1}{1} \\
\text { क }\end{array}$ & $\begin{array}{l}\text { 菅 } \\
\text { की }\end{array}$ & $\begin{array}{l}n \\
i \\
\frac{1}{2}\end{array}$ & $\begin{array}{l}\stackrel{0}{0} \\
\frac{1}{0}\end{array}$ & $\begin{array}{l}\hat{i} \\
\hat{i}\end{array}$ & $\begin{array}{l}\infty \\
\stackrel{i}{0} \\
\stackrel{0}{0}\end{array}$ \\
\hline
\end{tabular}




\begin{tabular}{|c|c|c|c|c|c|c|c|c|c|c|c|c|c|c|c|c|c|}
\hline 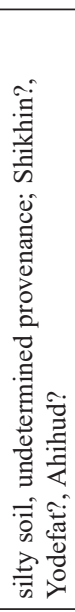 & 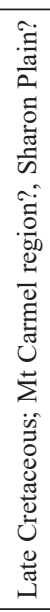 & 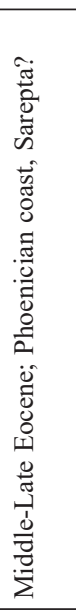 & 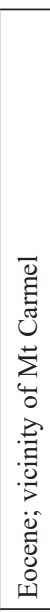 & 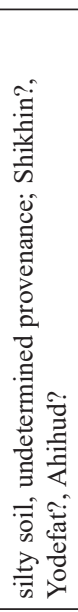 & 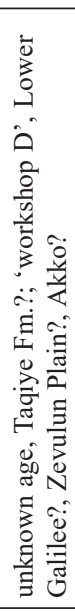 & 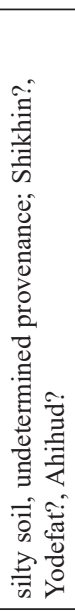 & 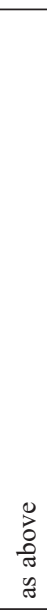 & 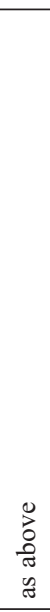 & 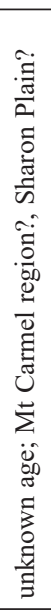 & 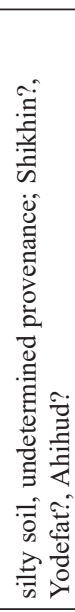 & 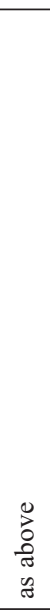 & 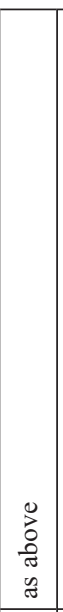 & 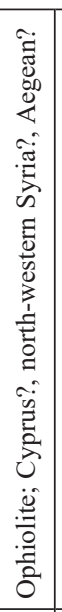 & 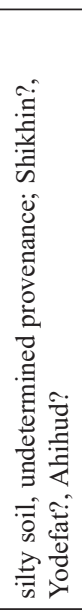 & $\begin{array}{l}0 \\
0 \\
0 \\
0 \\
0 \\
0 \\
0\end{array}$ & 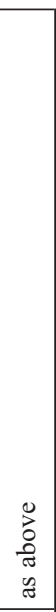 & 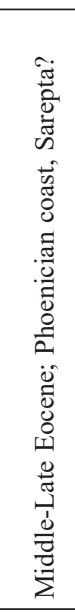 \\
\hline$\stackrel{\oplus}{G}$ & 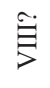 & $\underset{\leftrightarrows}{\rightleftarrows}$ & $\stackrel{\overbrace{}}{\leftrightarrows}$ & $\stackrel{\circlearrowright}{\varrho}$ & $\stackrel{P}{\geq}$ & $\stackrel{\circlearrowright}{ }$ & $\stackrel{\oplus}{=}$ & $\stackrel{\oplus}{\Theta}$ & $\underset{>}{\prime}$ & $\stackrel{\oplus}{\boxminus}$ & $\stackrel{\oplus}{\boxminus}$ & $\stackrel{\circlearrowright}{\Theta}$ & a. & $\stackrel{\circlearrowright}{\Theta}$ & $\stackrel{\ominus}{\ominus}$ & $\stackrel{\rho}{\ominus}$ & ¿ \\
\hline$\vec{\sim}$ & $\vec{\sim}$ & $=$ & ते & $\vec{\sim}$ & $\vec{\sim}$ & ते & ते & $\vec{\sim}$ & $\widetilde{N}$ & $\vec{\sim}$ & $\vec{\sim}$ & $\vec{\sim}$ & $\nabla$ & ते & $\vec{\sim}$ & $\stackrel{\sim}{ }$ & $=$ \\
\hline$\frac{\alpha}{\square}$ & $\stackrel{\mathscr{c}}{\underline{I}}$ & 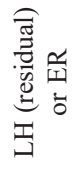 & $\frac{\alpha}{y}$ & $\frac{\alpha}{x}$ & $\underset{r}{\stackrel{\alpha}{1}}$ & $\frac{\sqrt{u r}}{d y}$ & $\frac{\alpha}{y y}$ & $\frac{\alpha}{r}$ & 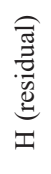 & $\stackrel{\alpha}{x y}$ & $\frac{\mathscr{c}}{\underline{I}}$ & $\frac{\alpha}{c y}$ & 亗 & $\frac{\alpha}{d y}$ & $\frac{\mathscr{r}}{\underline{I}}$ & $\stackrel{\mathscr{r}}{\breve{y}}$ & 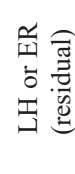 \\
\hline $\begin{array}{l}\overrightarrow{0} \\
0 \\
0 \\
\vec{\Xi} \\
\overrightarrow{2}\end{array}$ & $\begin{array}{l}\overrightarrow{0} \\
\tilde{D} \\
\tilde{g} \\
\overrightarrow{0}\end{array}$ & 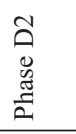 & $\begin{array}{l}\tilde{D} \\
0 \\
\tilde{g} \\
\frac{\tilde{J}}{2}\end{array}$ & $\begin{array}{l}\text { Õ } \\
\tilde{U} \\
\tilde{\Xi} \\
\tilde{\Xi}\end{array}$ & 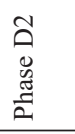 & $\begin{array}{l}\widetilde{0} \\
0 \\
\tilde{\Xi} \\
\tilde{\Xi} \\
\end{array}$ & $\begin{array}{l}\tilde{D} \\
\tilde{0} \\
\tilde{g} \\
\tilde{\Xi} \\
\end{array}$ & $\begin{array}{l}\tilde{~} \\
\tilde{\Xi} \\
\tilde{\Xi} \\
\tilde{\Xi}\end{array}$ & 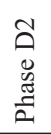 & $\begin{array}{l}\text { กี } \\
\tilde{J} \\
\tilde{z} \\
\frac{\pi}{2}\end{array}$ & 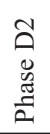 & 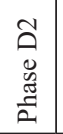 & $\begin{array}{l}\tilde{0} \\
\tilde{0} \\
\tilde{\Xi} \\
\tilde{\Xi}\end{array}$ & 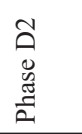 & $\begin{array}{l}\tilde{D} \\
0 \\
0 \\
\tilde{\Xi} \\
\frac{\pi}{2}\end{array}$ & 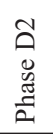 & 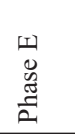 \\
\hline$\frac{\pi}{5}$ & 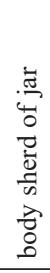 & 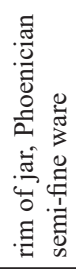 & 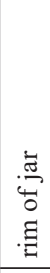 & 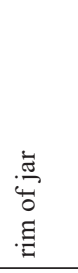 & 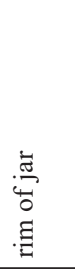 & 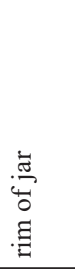 & 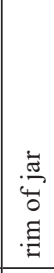 & 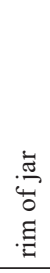 & 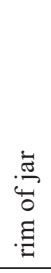 & 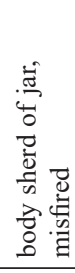 & 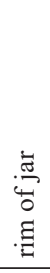 & 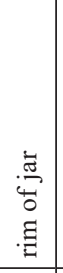 & 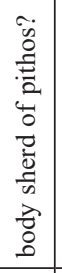 & 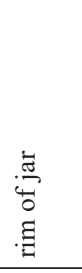 & 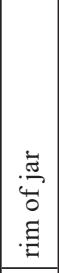 & 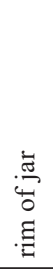 & 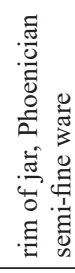 \\
\hline$\infty$ & 范 & $\begin{array}{l}m \\
\hat{a}\end{array}$ & $\frac{\vec{n}}{2}$ & $\begin{array}{c}\hat{\sigma} \\
\text { ळa }\end{array}$ & $\begin{array}{l}\circ \\
\stackrel{0}{0} \\
\sigma\end{array}$ & $\begin{array}{l}0 \\
\infty \\
\infty \\
\infty\end{array}$ & $\underset{\sigma}{\stackrel{\pi}{\alpha}}$ & \begin{tabular}{l}
$\tilde{n}$ \\
\multirow{2}{\alpha}{}
\end{tabular} & $\overrightarrow{\vec{a}}$ & 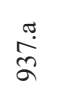 & \begin{tabular}{l}
0 \\
\multirow{2}{n}{} \\
$\alpha$
\end{tabular} & f & $\underset{n}{\stackrel{n}{n}}$ & $\vec{\alpha}$ & $\begin{array}{l}\pi \\
\infty \\
\infty \\
\infty \\
\infty\end{array}$ & $\underset{\infty}{\stackrel{\infty}{\infty}}$ & 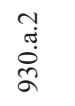 \\
\hline i & 尽 & $\begin{array}{l}\text { त्̀ } \\
\text { ڤิ }\end{array}$ & 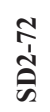 & 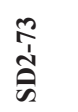 & $\begin{array}{l}\text { त् } \\
\text { ஸิ }\end{array}$ & 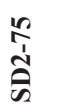 & 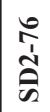 & ثิ่ & $\begin{array}{l}\stackrel{\infty}{1} \\
\tilde{\Lambda} \\
\text { क }\end{array}$ & 余 & $\begin{array}{l}\stackrel{\infty}{1} \\
\text { مิ }\end{array}$ & $\begin{array}{l}\bar{\infty} \\
\stackrel{1}{0} \\
\tilde{a}\end{array}$ & 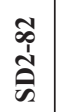 & $\begin{array}{l}\infty \\
\stackrel{1}{1} \\
\text { के }\end{array}$ & 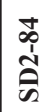 & $\begin{array}{l}\infty \\
\vdots \\
\tilde{n} \\
\text { مิ }\end{array}$ & 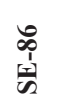 \\
\hline
\end{tabular}




\begin{tabular}{|c|c|c|c|c|c|c|c|c|c|c|c|c|c|c|}
\hline 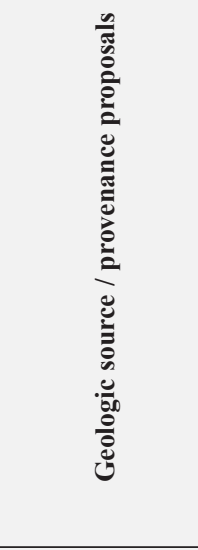 & 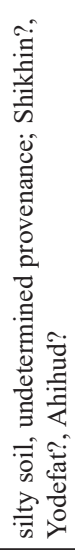 & 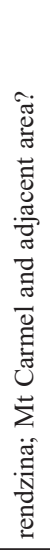 & 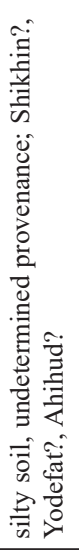 & 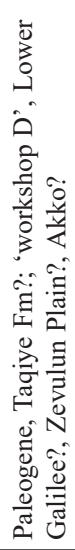 & 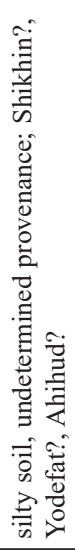 & $\begin{array}{l}0 \\
0 \\
0 \\
\tilde{\sigma} \\
\tilde{\sigma}\end{array}$ & $\begin{array}{l}0 \\
\text { Dे } \\
\text { ते } \\
\tilde{\sigma}\end{array}$ & 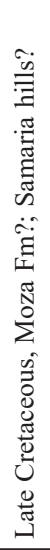 & 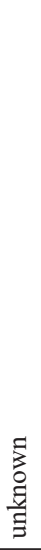 & 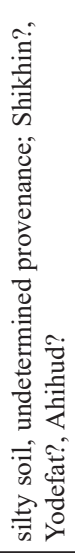 & 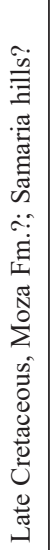 & 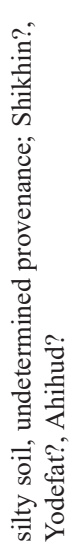 & 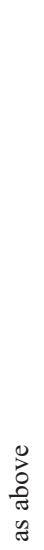 & 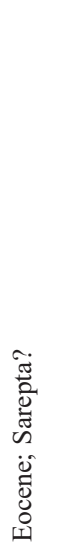 \\
\hline 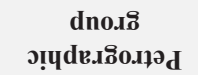 & $\stackrel{\oplus}{\boxminus}$ & 气 & 昌 & $\stackrel{9}{\stackrel{2}{2}}$ & 昌 & $\stackrel{n}{\boxminus}$ & 昌 & $\Xi$ & a. & $\stackrel{U}{\boxminus}$ & $\Xi$ & $\stackrel{\oplus}{\boxminus}$ & $\stackrel{9}{\boxminus}$ & $\stackrel{5}{2}$ \\
\hline dno.ı̊ ןəssə⿹ & $\vec{\sim}$ & $\vec{\sim}$ & ते & $\vec{\sim}$ & ते & ते & ते & $\hat{\sim}$ & ते & ลे & $\vec{\sim}$ & ते & సे & के हैं \\
\hline 8ิu!̣e & $\simeq$ & $\simeq$ & $\simeq$ & $\simeq$ & $\simeq$ & $\simeq$ & $\stackrel{\widetilde{r}}{\underline{y}}$ & 엄 & $\stackrel{\widetilde{r}}{\underline{I}}$ & $\simeq$ & $\simeq$ & $\simeq$ & 苈 & $\simeq$ \\
\hline 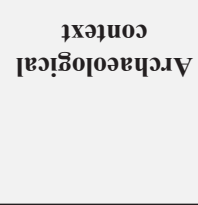 & 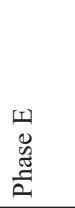 & 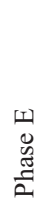 & 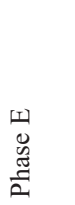 & 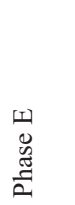 & 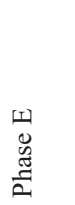 & 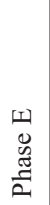 & $\begin{array}{l}\text { ㄸ } \\
0 \\
\mathscr{\Xi} \\
\text { D. }\end{array}$ & 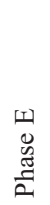 & 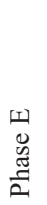 & $\begin{array}{l}\text { Ш } \\
0 \\
\mathscr{\Xi} \\
\text { D. }\end{array}$ & $\begin{array}{c}\text { I } \\
\tilde{D} \\
\tilde{\Xi} \\
\tilde{\Xi}\end{array}$ & 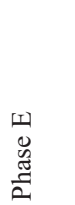 & 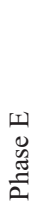 & 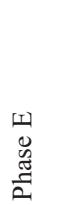 \\
\hline 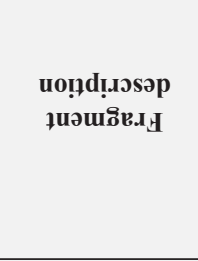 & 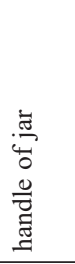 & 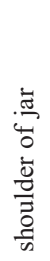 & 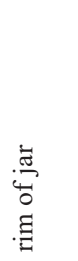 & 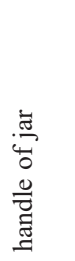 & 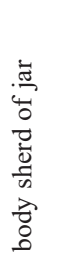 & 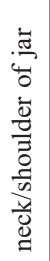 & 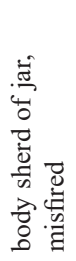 & 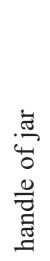 & 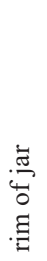 & 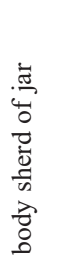 & 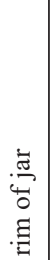 & 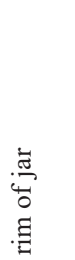 & $\begin{array}{l}\text { 离 } \\
\text { 另 } \\
\text { 声 }\end{array}$ & 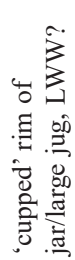 \\
\hline 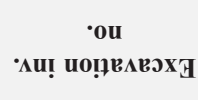 & ณ & $\underset{\infty}{\infty}$ & $\begin{array}{l}\pi \\
\dot{\infty} \\
\infty\end{array}$ & $\vec{\varnothing}$ & 官 & $\begin{array}{l}n \\
\infty \\
\infty\end{array}$ & ळ్ & $\bar{a}$ & $\begin{array}{l}0 \\
\dot{\infty} \\
\infty\end{array}$ & $\underset{\infty}{\infty}$ & $\hat{\dot{q}}$ & \begin{tabular}{l}
$n$ \\
\multirow{2}{n}{} \\
\\
$\infty$
\end{tabular} & $\frac{+}{\dot{\infty}}$ & $\begin{array}{l}\circ \\
\underset{b}{0} \\
\infty \\
\infty\end{array}$ \\
\hline Ioquís ә|dure & $\begin{array}{l}\hat{\infty} \\
\vdots \\
\text { c1 }\end{array}$ & $\begin{array}{l}\infty \\
0 \\
1 \\
\text { 㤐 }\end{array}$ & $\begin{array}{l}\text { के } \\
\text { 帛 }\end{array}$ & $\begin{array}{l}8 \\
\text { a } \\
\text { ch }\end{array}$ & 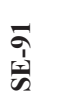 & 嵩 & ha & \begin{tabular}{l}
\multirow{1}{1}{} \\
离
\end{tabular} & 瓷 & 章 & 站 & 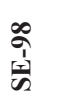 & बิ & $\begin{array}{l}8 \\
\frac{1}{5} \\
\frac{1}{n}\end{array}$ \\
\hline
\end{tabular}




\begin{tabular}{|c|c|c|c|c|c|c|c|c|c|c|c|c|c|c|c|c|c|}
\hline 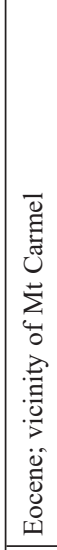 & 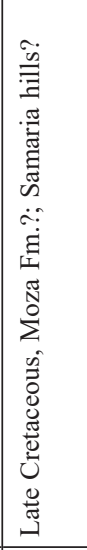 & 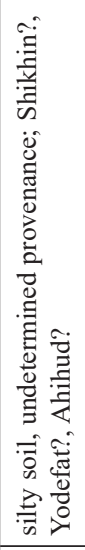 & 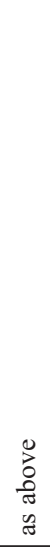 & 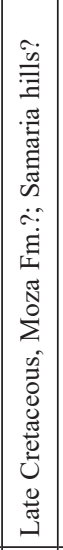 & 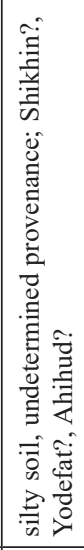 & 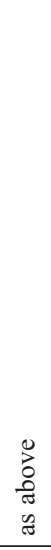 & 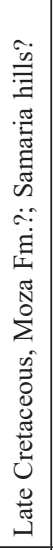 & 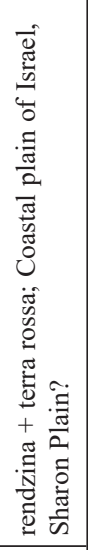 & 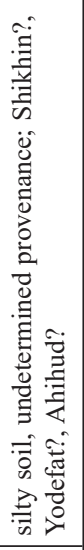 & 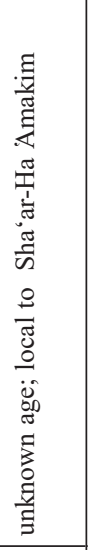 & 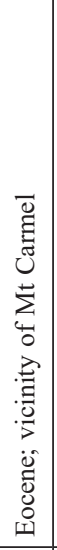 & 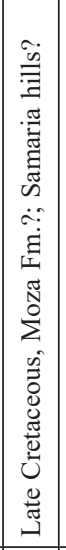 & $\begin{array}{l}0 \\
0 \\
0 \\
\tilde{\sigma} \\
\tilde{a} \\
\end{array}$ & 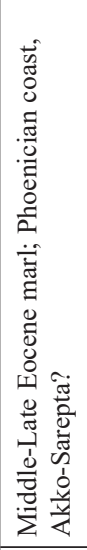 & 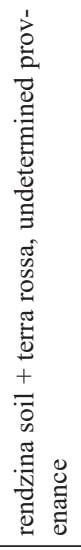 & 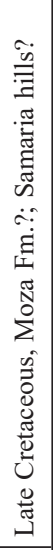 & 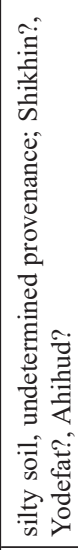 \\
\hline 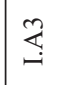 & $\Xi$ & 昌 & 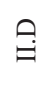 & $\Xi$ & $\stackrel{\mathscr{9}}{=}$ & $\stackrel{\oplus}{=}$ & $\Xi$ & a. & $\stackrel{\circlearrowright}{\Theta}$ & $\sigma$. & $\stackrel{n}{\leftrightarrows}$ & $\Xi$ & $\Xi$ & 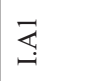 & a. & $\Xi$ & $\stackrel{\cup}{\Theta}$ \\
\hline ते & 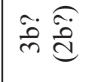 & ते & $\vec{\sim}$ & ते & ते & $\vec{\sim}$ & ते & 0 & ते & $\nabla$ & $\stackrel{0}{-}$ & $\stackrel{0}{=}$ & 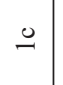 & 0 & 0 & ते & $\vec{\sim}$ \\
\hline 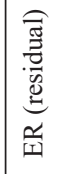 & $\simeq$ & $\simeq$ & $\simeq$ & $\simeq$ & $\simeq$ & $\simeq$ & $\simeq$ & $\simeq$ & $\simeq$ & $\ddot{\approx}$ & $\simeq$ & $\simeq$ & $\simeq$ & $\simeq$ & $\simeq$ & $\simeq$ & $\simeq$ \\
\hline 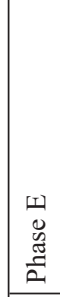 & 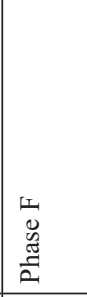 & 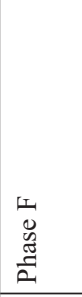 & 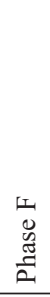 & 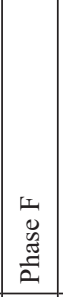 & 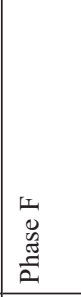 & 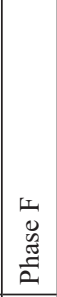 & $\begin{array}{l}1 \\
0 \\
0 \\
\tilde{g} \\
\tilde{\Xi} \\
\end{array}$ & 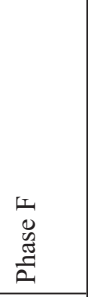 & 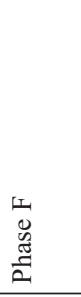 & 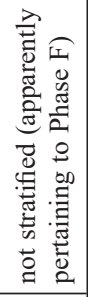 & 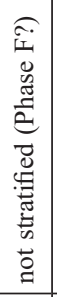 & 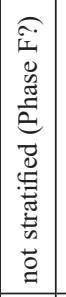 & 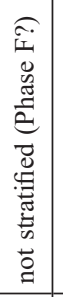 & 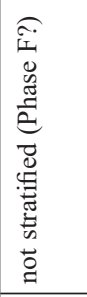 & 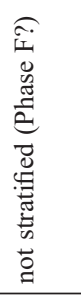 & 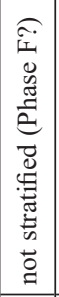 & 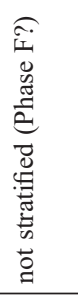 \\
\hline 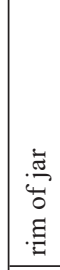 & 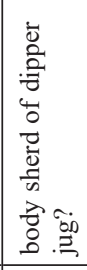 & 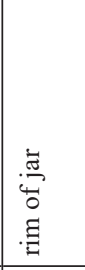 & 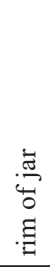 & 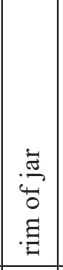 & 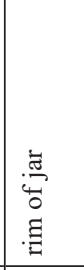 & 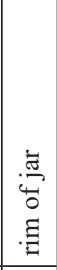 & 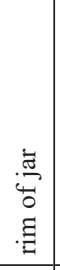 & 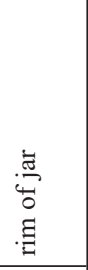 & 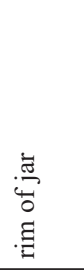 & छ & 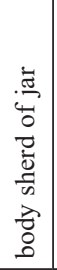 & 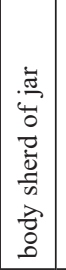 & 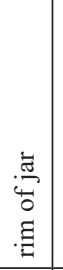 & 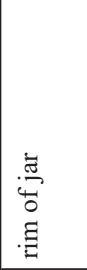 & 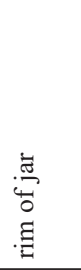 & 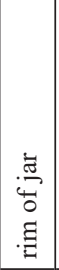 & 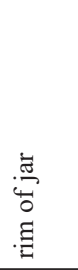 \\
\hline 节 & $\frac{\partial}{\sigma}$ & 官 & $\stackrel{+}{\stackrel{a}{\sigma}}$ & $\begin{array}{l}n \\
a \\
a\end{array}$ & 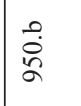 & 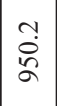 & $\hat{\sigma}$ & $\begin{array}{l}\vec{\sigma} \\
\stackrel{\sigma}{\sigma}\end{array}$ & 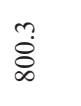 & నె & $\tilde{\Omega}$ & $\overrightarrow{8}$ & $\begin{array}{l}\text { त̊ } \\
\stackrel{\circ}{+}\end{array}$ & $\stackrel{\nabla}{\vec{\nabla}}$ & 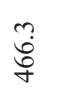 & $\begin{array}{l}= \\
\tilde{a} \\
\tilde{\sigma}\end{array}$ & 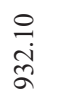 \\
\hline$\frac{\bar{\sigma}}{\frac{1}{1}}$ & $\frac{气}{\frac{1}{1}}$ & $\frac{m}{\frac{1}{1}}$ & $\frac{\Delta}{\frac{T}{d}}$ & $\mid \begin{array}{l}n \\
\stackrel{2}{1} \\
\frac{1}{n}\end{array}$ & $\frac{8}{\frac{1}{a}}$ & $\frac{\hat{a}}{\frac{1}{5}}$ & $\underset{\frac{1}{1}}{\frac{1}{\infty}}$ & $\frac{\partial}{\frac{1}{n}}$ & $\stackrel{\ominus}{\frac{1}{1}}$ & $\begin{array}{l}\exists \\
\bar{D} \\
\frac{1}{\infty}\end{array}$ & 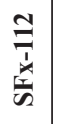 & $\frac{3}{7}$ & 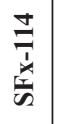 & $\frac{n}{7}$ & $\frac{0}{\sqrt[1]{n}}$ & $\frac{\Omega}{\bar{J}}$ & $\underset{\infty}{\stackrel{\infty}{\sigma}}$ \\
\hline
\end{tabular}




\begin{tabular}{|c|c|c|c|c|c|c|c|c|c|c|c|c|c|c|c|c|}
\hline 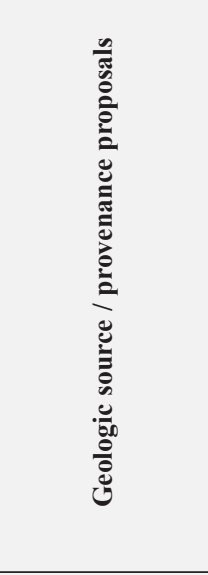 & 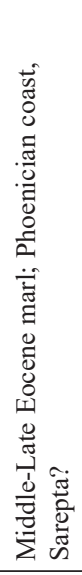 & 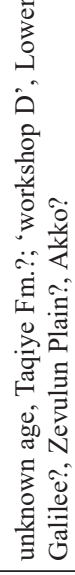 & 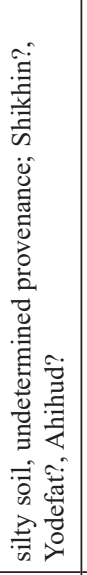 & 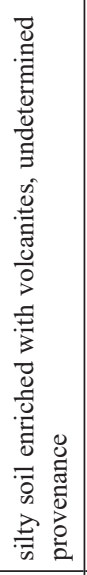 & 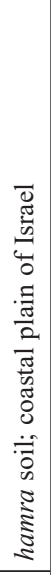 & 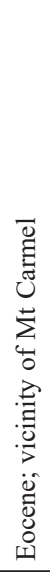 & $\begin{array}{l}\tilde{0} \\
\tilde{0} \\
0 \\
\tilde{\sigma} \\
\tilde{\sigma} \\
\end{array}$ & 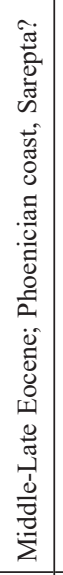 & 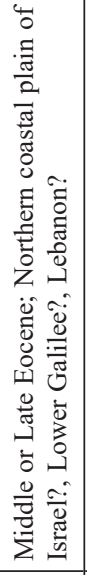 & 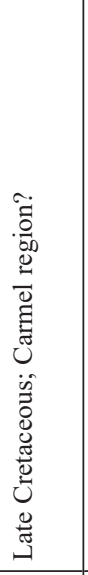 & 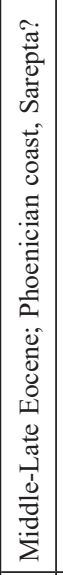 & 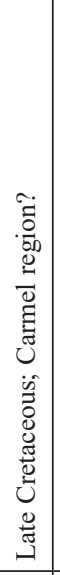 & 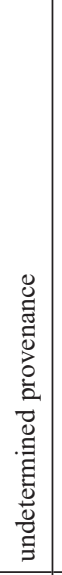 & 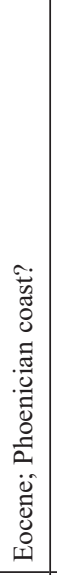 & 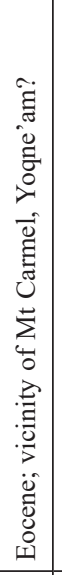 & 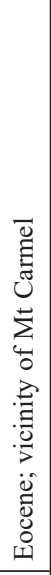 \\
\hline 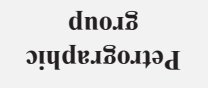 & 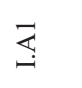 & $\stackrel{9}{\geq}$ & 昌 & $\stackrel{\ominus}{9}$ & 5 & $\stackrel{2}{\leftrightarrows}$ & $\underset{\grave{j}}{\tilde{m}}$ & $\underset{\Xi}{\longleftarrow}$ & $\stackrel{\overbrace{}}{\leftrightarrows}$ & a. & $\bar{\longleftarrow}$ & a. & a. & r. & $>$ & 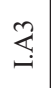 \\
\hline dno.ı̊̊ [əssə⿳亠口冋 & $=$ & $\widetilde{\sim}$ & $\begin{array}{l}+ \\
\dot{0} \\
\dot{\sim}\end{array}$ & $\widetilde{\sim}$ & $\cong$ & ते & $\overparen{\sim}$ & $\begin{array}{l}\frac{\pi}{\dot{d}} \\
\grave{\vdots}\end{array}$ & $\overparen{\text { ก }}$ & 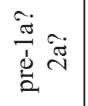 & $\approx$ & 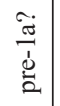 & $\hat{\sim}$ & $\pi$ & $\pi$ & $\vec{\sim}$ \\
\hline 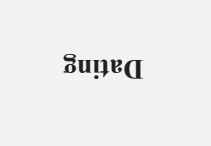 & 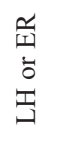 & $\tilde{i}$ & $\stackrel{\underline{\alpha}}{\underline{I}}$ & $\begin{array}{l}I \\
\vdots \\
0 \\
0\end{array}$ & 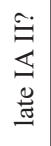 & $\simeq$ & 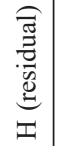 & 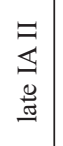 & $a$ & 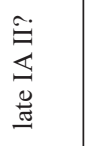 & a & 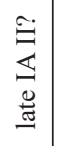 & $\simeq$ & \pm & 岑 & $\simeq$ \\
\hline 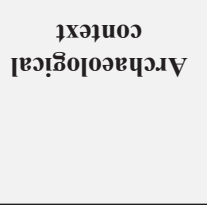 & 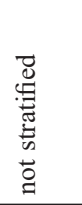 & 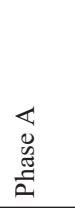 & $\begin{array}{l}\vec{D} \\
0 \\
\tilde{g} \\
\vec{a}\end{array}$ & $\begin{array}{l}\infty \\
0 \\
0 \\
\frac{\pi}{0}\end{array}$ & 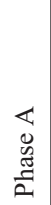 & $\begin{array}{l}\text { II } \\
\tilde{D} \\
\tilde{\Xi} \\
\frac{\pi}{2}\end{array}$ & $\begin{array}{l}\vec{D} \\
0 \\
\tilde{g} \\
\vec{\Xi}\end{array}$ & 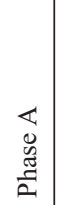 & 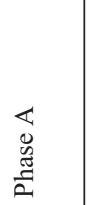 & 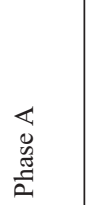 & 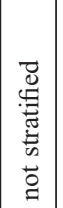 & 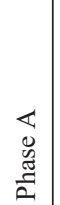 & 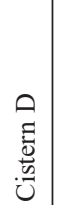 & $\begin{array}{l}m \\
0 \\
0 \\
\tilde{g} \\
\tilde{g}\end{array}$ & $\begin{array}{l}\overrightarrow{0} \\
\tilde{D} \\
\tilde{z} \\
\overrightarrow{0}\end{array}$ & 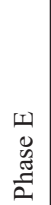 \\
\hline 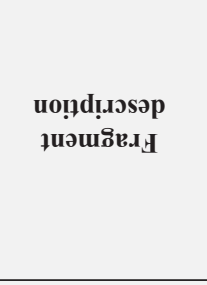 & 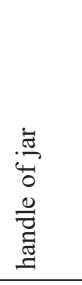 & 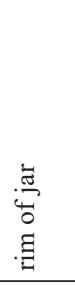 & 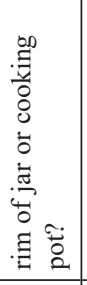 & 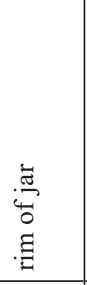 & 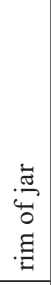 & 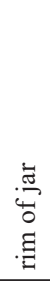 & 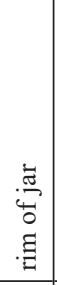 & 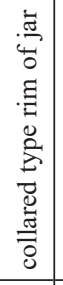 & 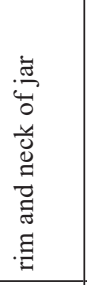 & 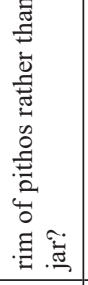 & 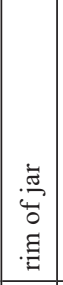 & $\begin{array}{c}0 \\
0 \\
0 \\
0 \\
0 \\
0 \\
. \\
.0 \\
0 \\
0 \\
. \\
.\end{array}$ & 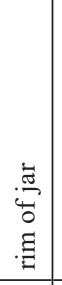 & 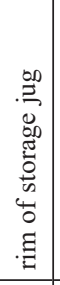 & 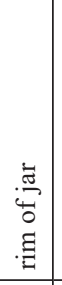 & 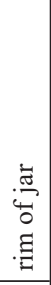 \\
\hline 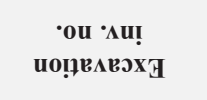 & $\begin{array}{l}\stackrel{0}{2} \\
\stackrel{2}{a}\end{array}$ & $\underset{\infty}{\stackrel{m}{+}}$ & 离 & $\begin{array}{l}\stackrel{0}{0} \\
\frac{1}{\sigma}\end{array}$ & $\begin{array}{l}\infty \\
\stackrel{0}{0} \\
\infty\end{array}$ & $\stackrel{\circ}{\stackrel{a}{a}}$ & 苞 & $\overrightarrow{\tilde{g}}$ & $\stackrel{n}{\tilde{j}}$ & ऽ̆ & $\begin{array}{l}\infty \\
\dot{a} \\
2\end{array}$ & $\overrightarrow{6}$ & జ్ర & $\begin{array}{l}\dot{y} \\
\ddot{\hat{\alpha}}\end{array}$ & $\begin{array}{c}\widetilde{\sigma} \\
\stackrel{్}{i}\end{array}$ & \begin{tabular}{c}
$\sim$ \\
\multirow{2}{*}{} \\
$\infty$
\end{tabular} \\
\hline Ioquiss ə[durs & $\frac{\partial}{\bar{y}}$ & $\frac{\text { đิ }}{\frac{1}{4}}$ & $\overline{\bar{I}}$ & 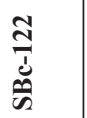 & $\frac{2}{\stackrel{1}{4}}$ & $\frac{d}{\frac{1}{a}}$ & $\frac{\mathscr{2}}{\frac{1}{1}}$ & 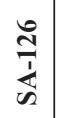 & $\frac{\hat{i}}{\sum_{\infty}}$ & $\frac{\infty}{\stackrel{1}{\pi}}$ & 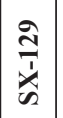 & $\frac{8}{\frac{m}{1}}$ & $\begin{array}{c}\bar{m} \\
\overline{\dot{d}} \\
\text { की }\end{array}$ & $\begin{array}{l}\tilde{\omega} \\
\stackrel{\tilde{J}}{3} \\
\tilde{\omega}\end{array}$ & $\frac{m}{\frac{m}{1}}$ & $\begin{array}{l}\frac{7}{m} \\
\frac{5}{5}\end{array}$ \\
\hline
\end{tabular}




\begin{tabular}{|c|c|c|c|c|c|c|c|c|c|c|c|c|c|c|c|c|c|}
\hline 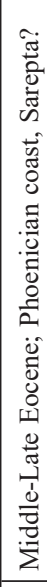 & 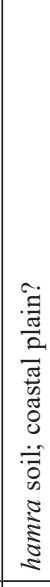 & 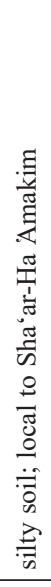 & $\begin{array}{l}\tilde{j} \\
\tilde{0} \\
\tilde{\sigma} \\
\tilde{\sigma} \\
\tilde{\sigma}\end{array}$ & 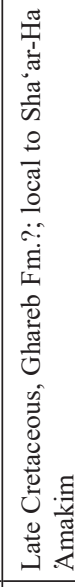 & 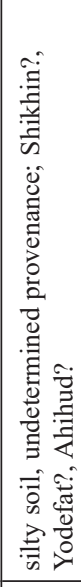 & $\begin{array}{l}0 \\
8 \\
0 \\
0 \\
0 \\
0\end{array}$ & 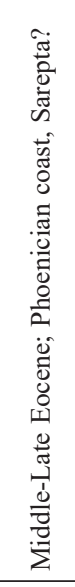 & 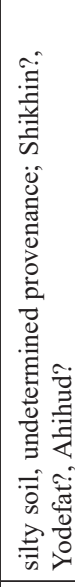 & $\begin{array}{l}0 \\
\delta \\
\tilde{\sigma} \\
\tilde{\sigma} \\
\tilde{\sigma}\end{array}$ & 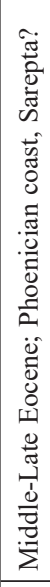 & 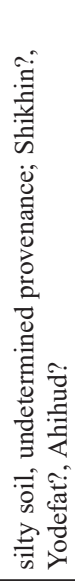 & \begin{tabular}{|l}
0 \\
0 \\
0 \\
$\pi$ \\
0 \\
0 \\
\end{tabular} & 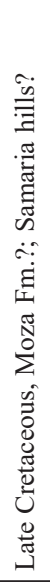 & $\begin{array}{l}0 \\
0 \\
\tilde{\sigma} \\
\tilde{\sigma} \\
\tilde{\sigma}\end{array}$ & 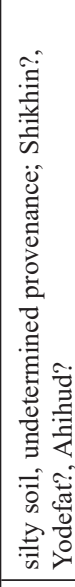 & 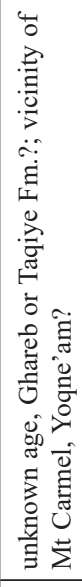 & 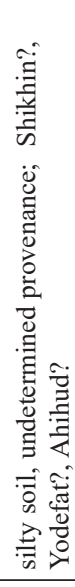 \\
\hline ¿ & a. & 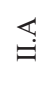 & $\overleftrightarrow{\Xi}$ & $\stackrel{\substack{1\\
}}{\stackrel{2}{2}}$ & 兒 & $\stackrel{n}{\boxminus}$ & $\underset{\leftrightarrows}{\rightleftarrows}$ & $\underset{\exists}{\cup}$ & $\stackrel{\rho}{\ominus}$ & $\rightleftarrows$ & $\stackrel{\cup}{\Theta}$ & $\stackrel{n}{\boxminus}$ & $\Xi$ & $\Xi$ & $\stackrel{\oplus}{\boxminus}$ & $>$ & $\stackrel{n}{\boxminus}$ \\
\hline$\stackrel{\pi}{I}$ & $\nabla$ & $\nabla$ & $\nabla$ & $\nabla$ & $\vec{\sim}$ & $\vec{\sim}$ & $=$ & ते & ते & $\ddot{\theta}$ & $\vec{\sim}$ & ते & $\vec{\sim}$ & $\vec{\sim}$ & ते & $\nabla$ & $\nabla$ \\
\hline & $\simeq$ & a. & $\frac{\tilde{\alpha}}{-1}$ & 守 & $\simeq$ & $\simeq$ & 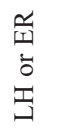 & $\frac{\alpha}{r I}$ & $\simeq$ & Ј & $\simeq$ & $\simeq$ & $\simeq$ & 岇 & $\simeq$ & o. & $a$. \\
\hline 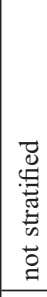 & 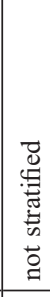 & 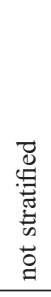 & 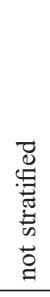 & \begin{tabular}{|l}
$\tilde{\omega}$ \\
$\tilde{g}$ \\
$\tilde{g}$ \\
$\tilde{q}$
\end{tabular} & 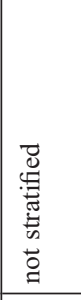 & 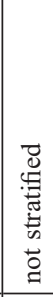 & 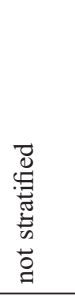 & 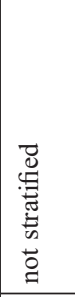 & 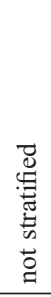 & 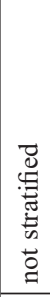 & 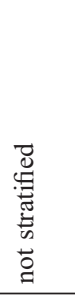 & 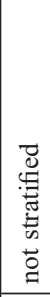 & 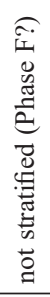 & 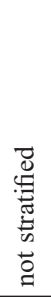 & 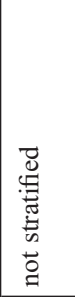 & 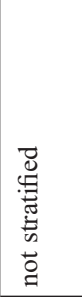 & 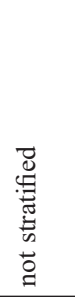 \\
\hline : & 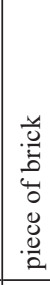 & 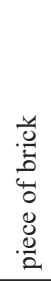 & 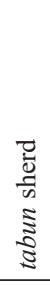 & 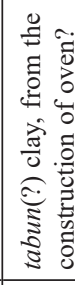 & 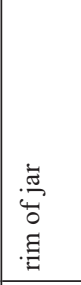 & 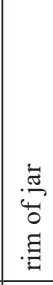 & 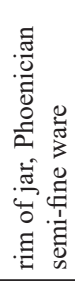 & 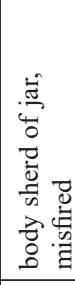 & 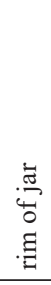 & 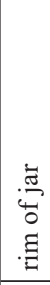 & 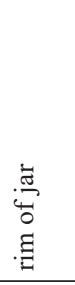 & 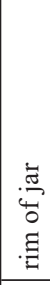 & 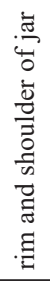 & 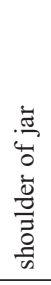 & 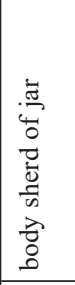 & 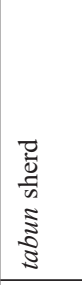 & 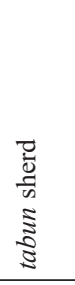 \\
\hline $\begin{array}{l}\infty \\
a \\
a\end{array}$ & $\stackrel{\infty}{\stackrel{\sim}{~}}$ & $\begin{array}{l}2 \\
\text { eे } \\
\Sigma\end{array}$ & ' & 0 & $\begin{array}{l}0 \\
0 \\
\infty \\
\infty\end{array}$ & $\begin{array}{l}0 \\
\dot{\delta} \\
+\end{array}$ & 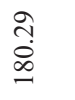 & 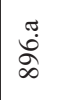 & تृ & $\begin{array}{l}0 \\
\dot{8} \\
\dot{8}\end{array}$ & : & $\begin{array}{l}\pi \\
\dot{\sigma} \\
\dot{\sigma}\end{array}$ & $\underset{\infty}{=}$ & 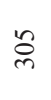 & $\begin{array}{l}0 \\
\dot{8} \\
\infty\end{array}$ & ' & ' \\
\hline$\frac{6}{2}$ & 党 & $\frac{n}{n}$ & $\frac{\hat{n}}{\frac{1}{1}}$ & 官 & $\frac{F}{\bar{z}}$ & 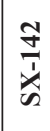 & 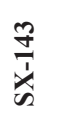 & 尃 & $\frac{10}{\frac{1}{1}}$ & $\frac{0}{j}$ & $\frac{f}{\frac{1}{d}}$ & 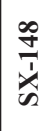 & $\frac{\frac{\partial}{d}}{\frac{d}{\omega}}$ & $\frac{\sqrt{n}}{\frac{\pi}{x}}$ & $\frac{\bar{n}}{\frac{\pi}{\pi}}$ & 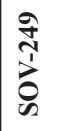 & 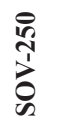 \\
\hline
\end{tabular}




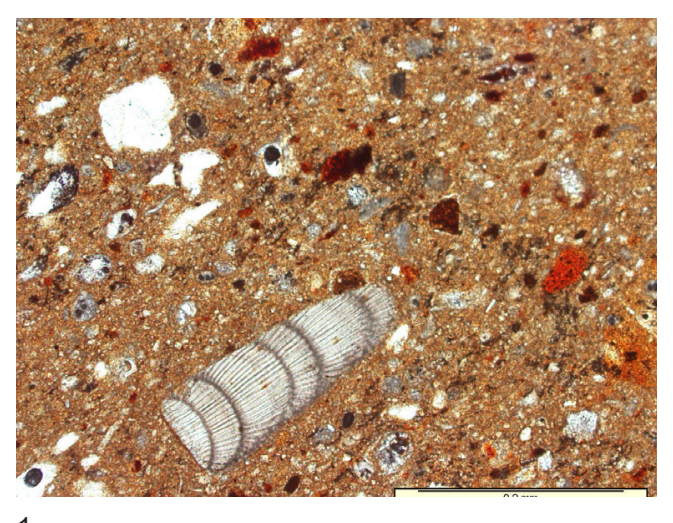
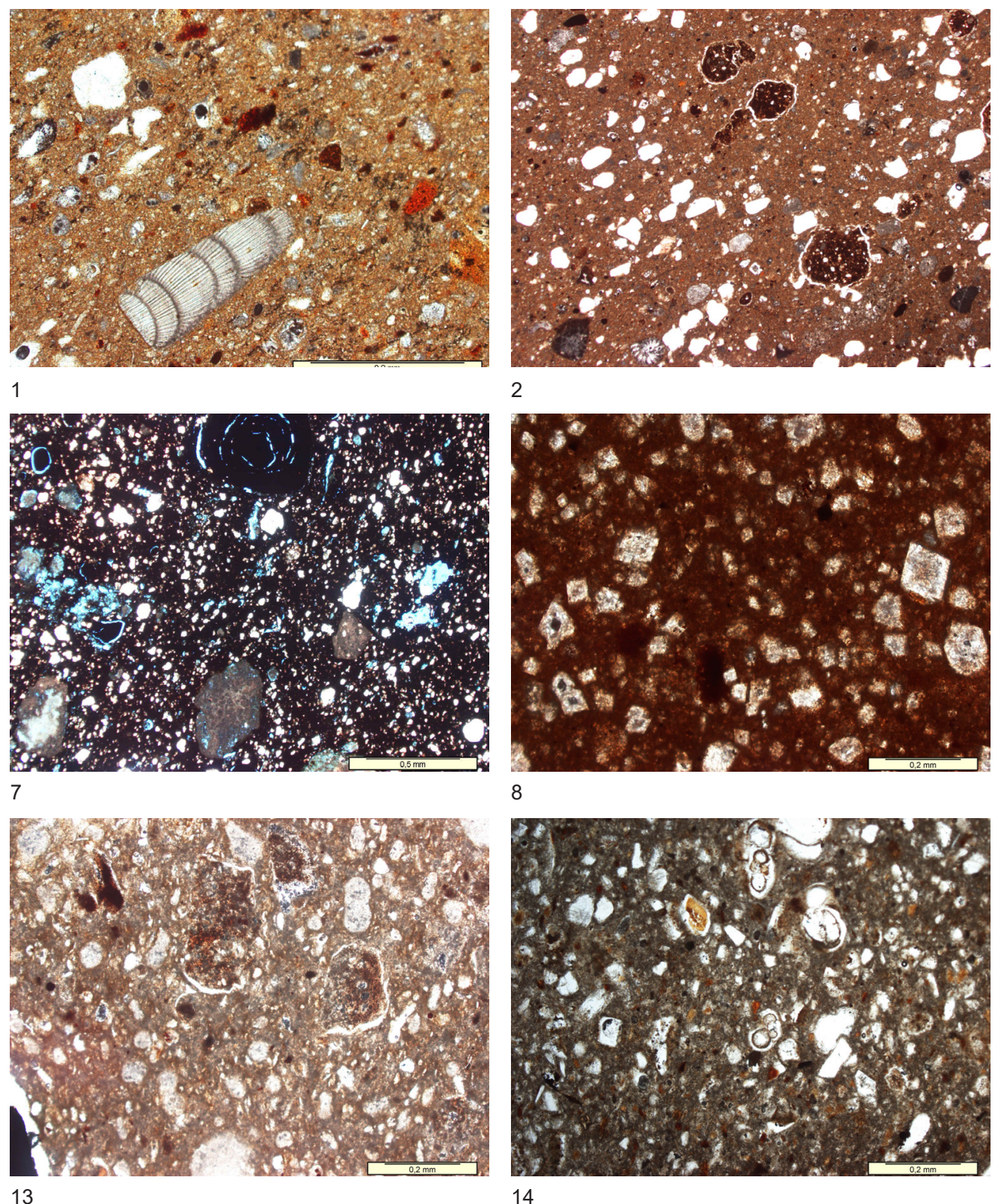

7. Petrographic groups (PG) distinguished among pottery from Sha‘ar-Ha Amakim: 1. PG I.A1, SX-146 (PPL); 2. PG
I.A2, SBc-15 (PPL); 3. PG I.A3, SDl-125 (PPL) 4. PG II.A, SDc-54; 5. PG II.B, SE-99 (PPL); 6. PG II.C) SF-110

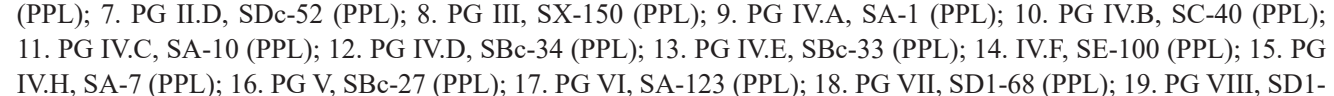
IV.H, SA-7 (PPL); 16. PG V, SBC
70 (PLL) (Phot. J. Michniewicz)
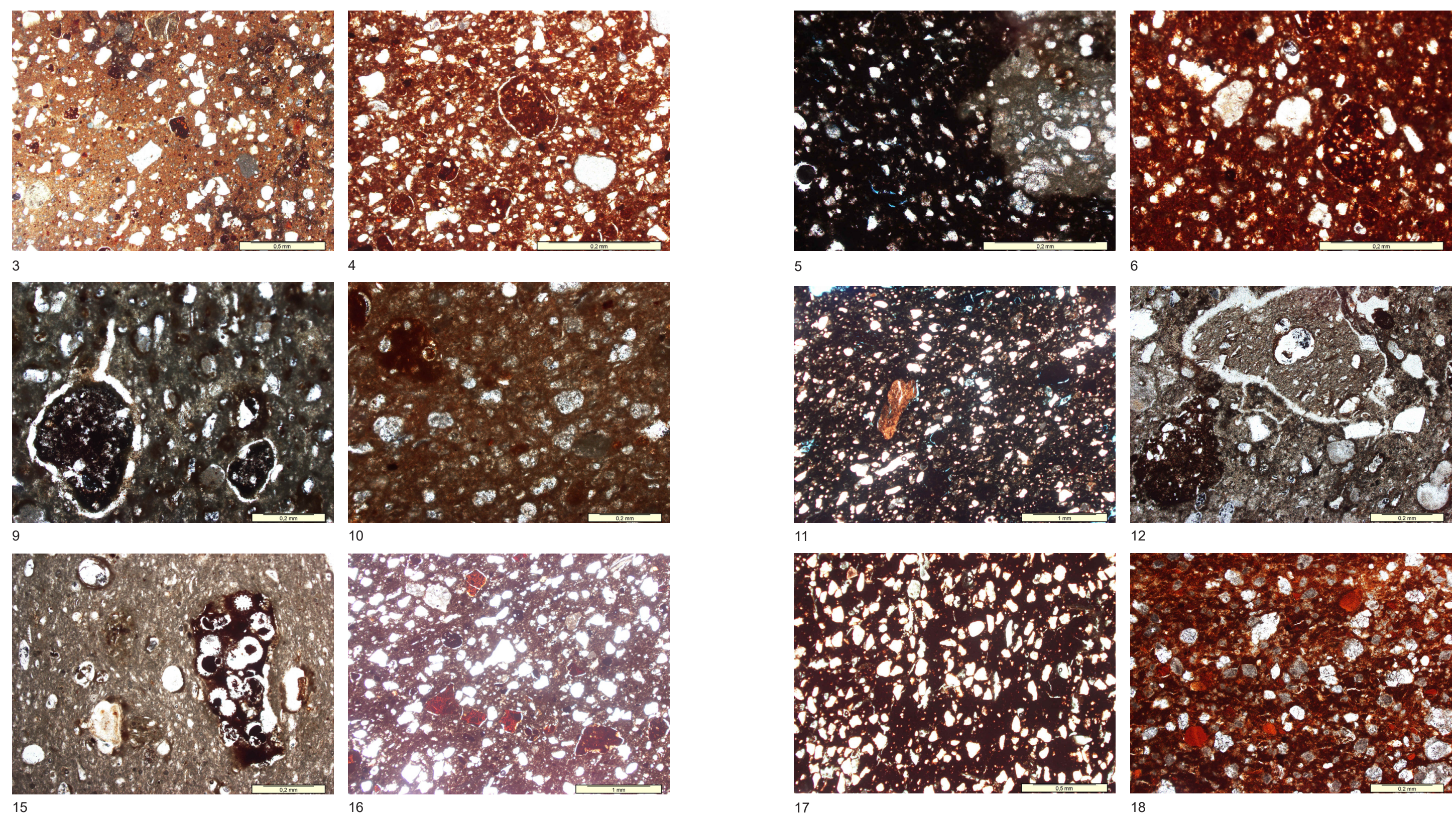
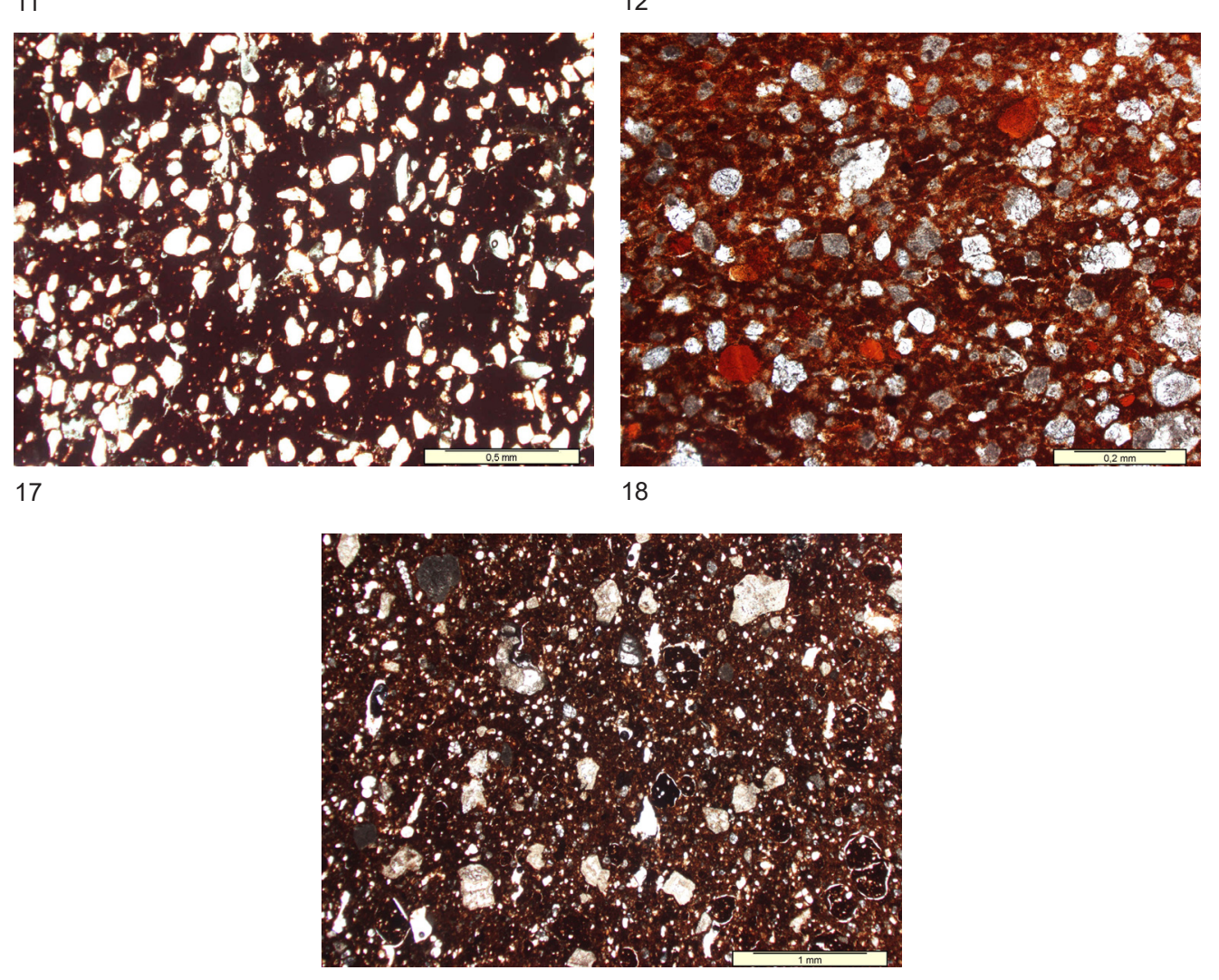


\section{ÉTUDES et TRAVAUX XXX / 2017}

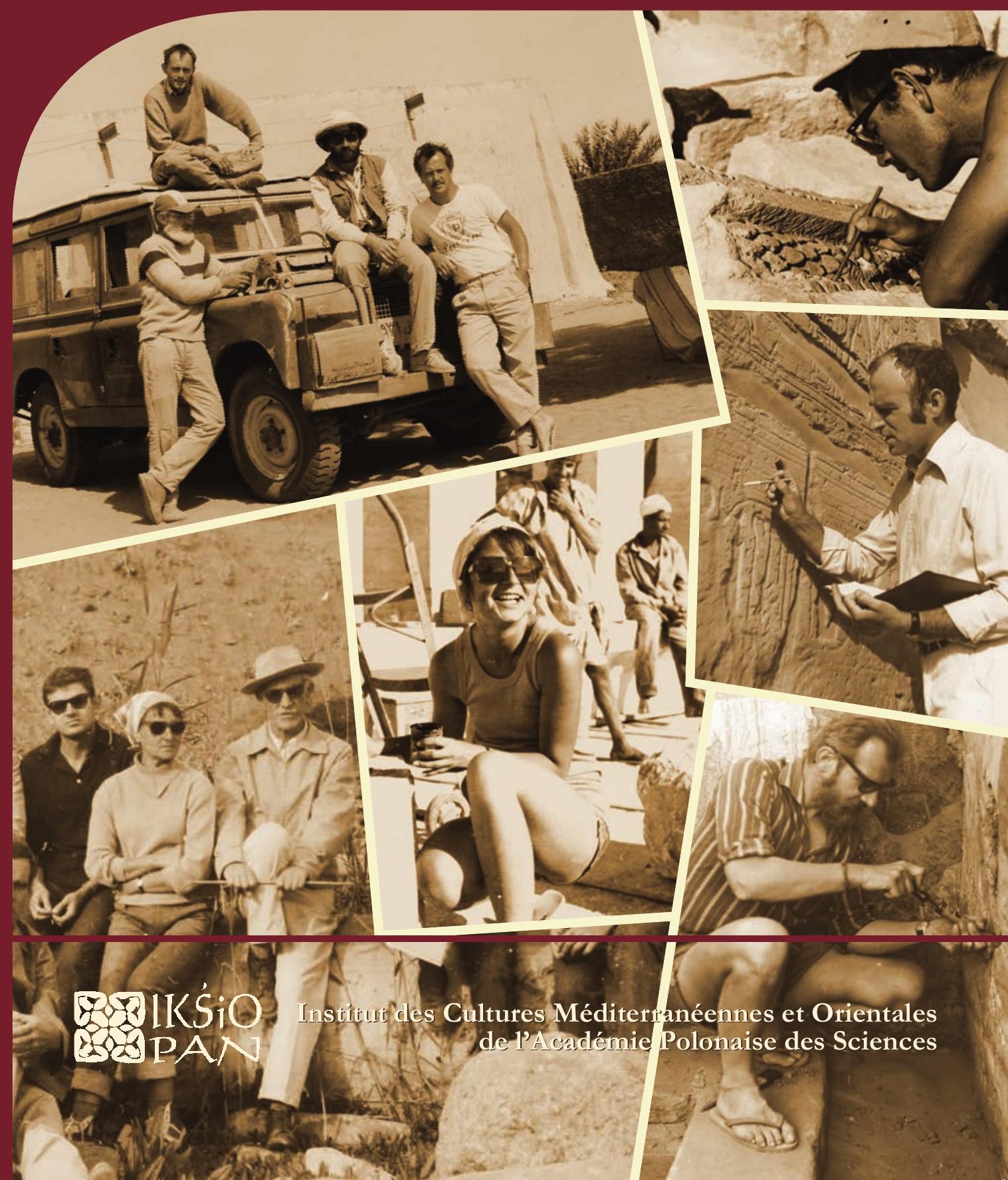




\title{
COMITÉ DE RÉDACTION SCIENTIFIQUE
}

Maciej Makowski - rédacteur en chef

Jadwiga Iwaszczuk - rédacteur et sécretaire de la rédaction

Mariusz Drzewiecki - rédacteur

Maciej G. Witkowski - rédacteur

\section{CONSEIL SCIENTIFIQUE DU JOURNAL}

M. Kobusiewicz (IAE PAS, Warszawa), E. Laskowska-Kusztal (IMOC PAS, Warszawa),

D. Michaelides (University of Cyprus, Nicosia),

J.Ch. Moretti (IRAA-MOM, Université de Lyon 2/CNRS),

D. Raue (Ägyptisches Museum der Universität Leipzig), P. Reynolds (ICREA, Barcelona),

D. Welsby (British Museum, London)

\section{COMITÉ SCIENTIFIQUE DE LECTURE}

J. Holaubek (Institut für Ägyptologie, Wien), S. Ikram (AUC, Cairo),

K. Innemée (Universiteit Leiden), J. McKenzie (Faculty of Oriental Studies, University of Oxford),

N. Strudwick (University of Cambridge), A. Loprieno-Gnirs (Universität Basel),

Ch.E. Loeben (Museen für Kulturgeschichte, Hannover), Y. Tristant (Macquarie University, Sydney),

V.W.J. van Gerven Oei (University of Aberdeen), A. Peignard-Giros (HiSoMA-MOM, Université de Lyon 2/CNRS), J.A. Ostrowski, E. Papuci-Władyka, J. Śliwa (IA JU, Kraków), R. Czerner (WUST, Wrocław), A. Ćwiek (IA AMU, Poznań), M. Wiewióra (IA NCU, Toruń), K. Domżalski

(IAE PAS, Warszawa), K.O. Kuraszkiewicz (DE FOS UW), M. Barwik, P. Bieliński, P. Dyczek, W. Godlewski, D. Ławecka, S. Rzepka, J. Żelazowski, M. Gawlikowski, J. Młynarczyk, A. Niwiński, T. Sarnowski, D. Szeląg, T. Waliszewski (IA UW, Warszawa)

\section{RÉDACTEUR THÉMATIQUE DU VOLUME \\ Barbara Lichocka}

\author{
AIDE RÉDACTION TECHNIQUE \\ Dorota Dobrzyńska, Mariusz Drzewiecki
}

REVUE DES TEXTES ANGLAIS

Jo Harper 
ÉTUDES et TRAVAUX XXX 
INSTYTUT KULTUR ŚRÓDZIEMNOMORSKICH I ORIENTALNYCH POLSKIEJ AKADEMII NAUK

\section{STUDIA i PRACE}

XXX

\section{Ro IKŚSiO \\ ESA PAN}

WARSZAWA

2017 
INSTITUT DES CULTURES MÉDITERRANÉENNES ET ORIENTALES DE L'ACADÉMIE POLONAISE DES SCIENCES

\section{ÉTUDES et TRAVAUX}

XXX

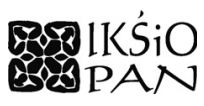

VARSOVIE

2017 
Publication scientifique financée dans le cadre du programme du Ministre de la Science et de l'Éducation Supérieure

« Programme National de Développement de l’Humanistique » pour les années 2016-2021 (projet no 3bH 150099 83)

\title{
HARODOWY PROGRAM ROZWOJU HUMANISTYKI
}

\author{
Copyright (C) \\ Instytut Kultur Śródziemnomorskich i Orientalnych PAN \\ et les Auteurs \\ Warszawa 2017
}

\author{
ISSN 2084-6762 \\ (avant $2011: 0079-3566$ ) \\ e-ISSN 2449-9579 \\ Version première en papier, imprimée en Pologne - 150 copies \\ Version électronique accessible sur \\ http://www.etudesettravaux.iksiopan.pl
}

Édition: Polskie Towarzystwo Historyczne et Wydawnictwo Neriton, Warszawa

Conception générale de couverture : J. Iwaszczuk

Photos de couverture : En haut, à gauche. Vieille Dongola 1991, S. Jakobielski

(debout à gauche), K. Pluskota (debout à droite), B. Żurawski (assis sur le camion)

et P. Wierzbicki (assis sur le camion) (de la collection de B. Żurawski)

En haut, à droite. Palmyre 1964, M. Marciniak au travail (phot. A. Dziewanowski)

Au centre. E. Laskowska-Kusztal au travail (de la collection de E. Laskowska-Kusztal)

En bas, à gauche. Tell Atrib 1962 ; de gauche : T. Biniewski, M. Marciniak, K. Kołodziejczyk,

K. Michałowski, A. Ostrasz, S. Jakobielski et S. Jasiewicz devant eux

(de la collection de IKŚSiO PAN).

En bas, à droite. Vieille Dongola 1976, S. Jakobielski nettoyant le mur (phot. M. Steinborn).

Au centre, à droite, K. Myśliwiec en train des travaux de documentation (de la collection de IKŚiO PAN) 


\section{Table des matières}

BARBARA LICHOCKA

Ergon agathon

Hartwig Altenmüller

$\mathrm{Zu}$ den Feindbildern auf den Zauberstäben des Mittleren Reiches und der Zweiten

Zwischenzeit

Nathalie Beaux

Des $m s w n s w$ de Thoutmosis III à Deir el-Bahari

Briant Bohleke, Nigel Strudwick

A Label for Opening of the Mouth Implements from the Burial of Senneferi (TT99)

and Remarks on the Ritual

Rosa Maria Bonacasa Carra, Nicola Bonacasa

Nuovi dati sugli edifici termali di Sabratha

EDWARD BROVARSKI

A Fragmentary Carrying Chair Scene in Salt Lake City, Utah

Julia Burdajewicz

Wall Painting Decoration from the North-West Church in Hippos-Sussita

of the Decapolis

Mariusz BURDAJEWICZ

From Pagan Temple to Church in Late Antiquity Palestine. A View from

Hippos-Sussita

MAREK ChlodNicki

Early Dynastic Bead Workshops at the Central Kom of Tell el-Farkha.

Patryk ChudziK, Mariusz Caban

Observations on the Architecture of the Tomb of Horhotep in Western Thebes

Krzysztof M. Cialowicz

New Discoveries at Tell el-Farkha and the Beginnings of the Egyptian State.

Amr EL-TiebI

Four Wooden New Kingdom Female Statuettes in the Egyptian Museum, Cairo 


\section{Naguib KanaWATI}

Ritual Marriage Alliances and Consolidation of Power in Middle Egypt during the Middle Kingdom

Adam Łajtar, Jolanta Mlynarczyk

A Faction Acclamation Incised on a Pithos Found Near the North-West Church at Hippos (Sussita)

Adam ŁaJTAR, Grzegorz OchaŁa

Two Private Prayers in Wall Inscriptions in the Faras Cathedral

Adam Łajtar, Anna Poludnikiewicz

Medicinal Vessels from Tell Atrib (Egypt)

JaCeK Michniewicz, Jolanta MlynarczyK

Petrographic Variability of the Fabrics of Wine Jars from Sha'ar-Ha Amakim as a Reflection of Differences in Their Provenance and Chronology

Iwona ModrzewsKa-PianetTI

Les importations d'amphores Dressel 20 en Gaule Cisalpine

Arthur SEgal

Samaria-Sebaste. Portrait of a polis in the Heart of Samaria 409

JOACHIM ŚLIWA

The Motif of a 'Blind Harper' in an Unexpected Place

MONIKA WIĘCH

Searching for the Kitchen in the Early Roman Phase of the 'Hellenistic' House at Nea Paphos (Cyprus)

Abréviations 
THE VOLUME IS PUBLISHED TO CELEBRATE

THE $60^{\text {TH }}$ ANNIVERSARY

OF THE ESTABLISHMENT OF

THE RESEARCH CENTRE FOR MEDITERRANEAN ARCHAEOLOGY POLISH ACADEMY OF SCIENCES

FOUNDED IN 1956

WHOSE MISSION IS CONTINUED BY

THE INSTITUTE OF MEDITERRANEAN AND ORIENTAL CULTURES

OF THE POLISH ACADEMY OF SCIENCES 